\title{
فاعلية التعلم النقال القائم على وحدات التعلم الرقمية في إنتاج الحتوى الرقمي لدى طلاب الدراسات العليا بكلية التربية
}

\author{
إعداد \\ الباحث / ياسر اهمد عبد المعطى بدر
}




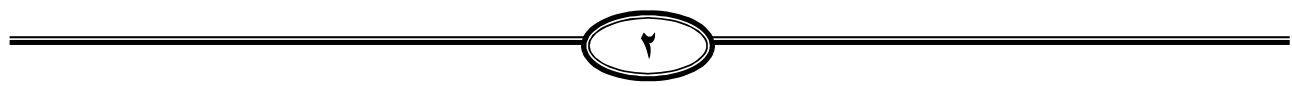




\title{
فاعلية التعلم النقال القائم على وحدات التعلم الرقمية \\ في إنتاج المتوى الرقمي لدى طلاب الدراسات العليا بكلية التربية التهية
}

\author{
| (إعداد \\ الباحث /ياسر احمد عبد المعطبدر
}

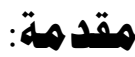

ِِّْ ظل ما يشهده العالم اليوم من ثورة كبيرة وانتشار واسـع لاستخدام الأجهزة

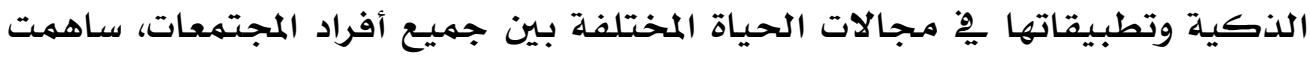

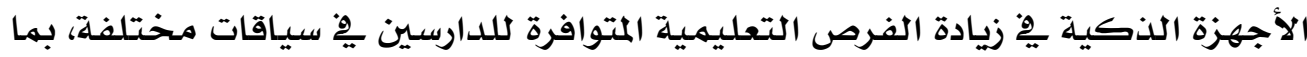

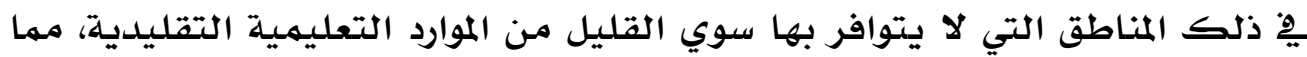

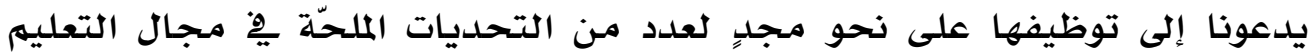

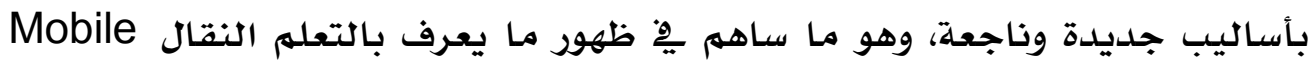
.Learning

ويعد استخدام التقنية الرقمية المحمولة والمتتقلة نهطًا من أنهاط تقديه المحتوى

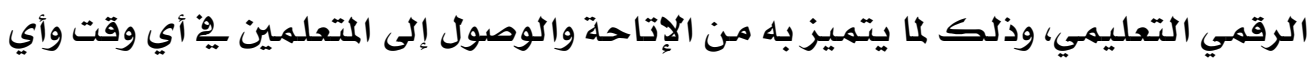

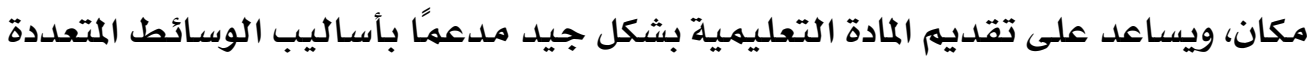

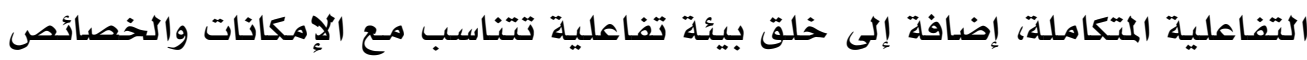
التي تقدمها تقنيات الهواتف النقالة، مـع ضرورة الأخذ بعين الاعتبـار جودة التصديميه

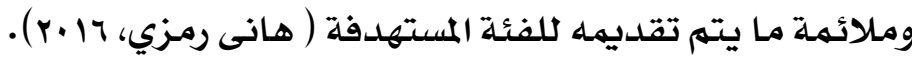

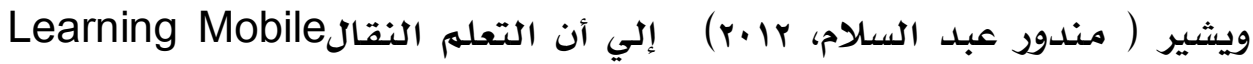
Systems

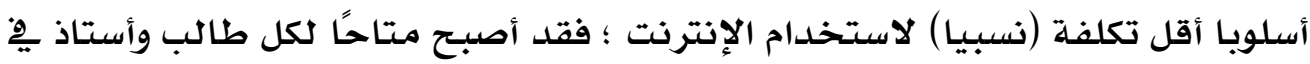

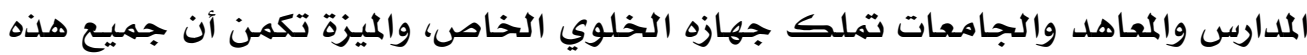

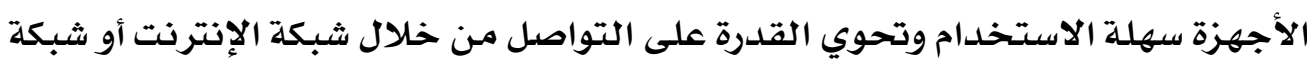

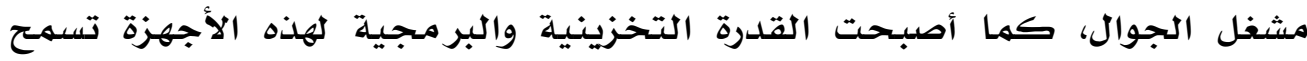

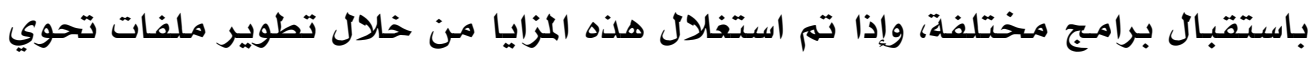

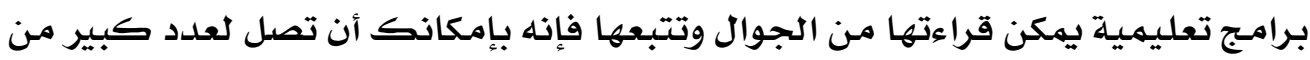


الطلاب بوقت واحد يخ أي مكان وإدارة جزء من العملية التعليمية بكل سهولة لعشرات

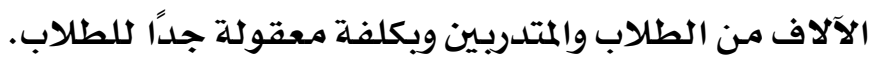

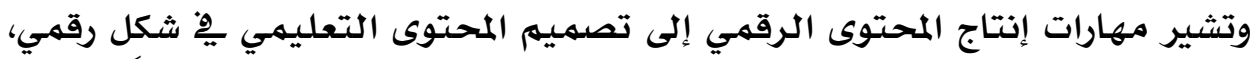

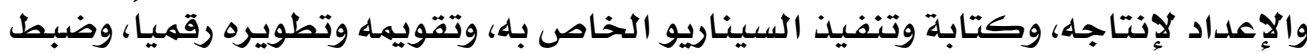

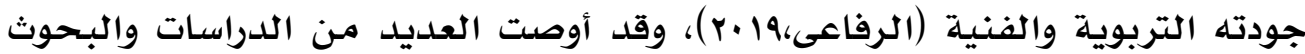

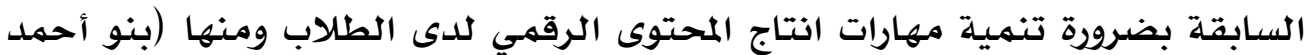

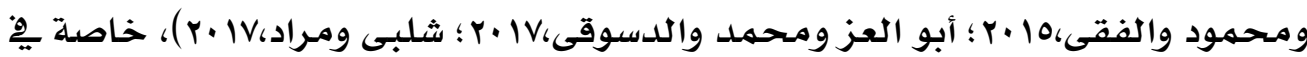

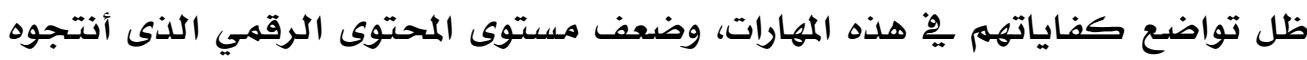

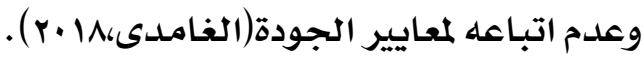
ويرتبط موضوع تصميه المحتوى الرقهي النقال وانتاجه وإخراجه بها يحويه من فن

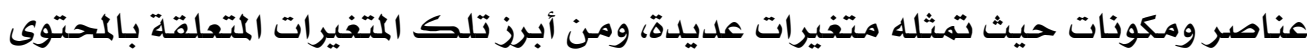

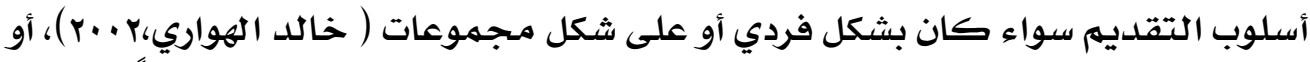

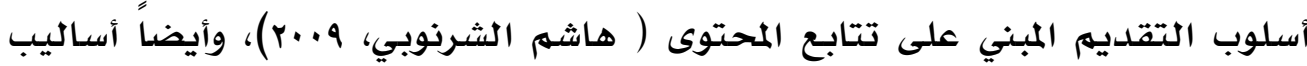

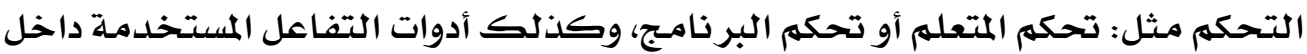

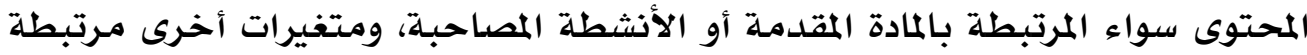

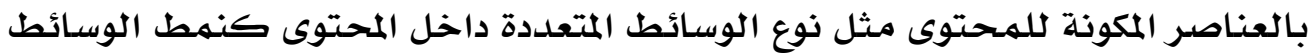

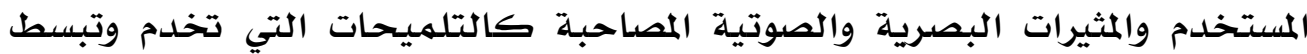
المحتوى المعروض للوصول إلى الأهداف المرصودة لتحقيقها ( ابراهيم محمود، ج . . ). ومن خلال ما سبق يمكن القول أن المحتوى الرقهي النقال بها يحويه من عناصر

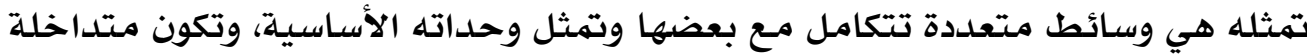

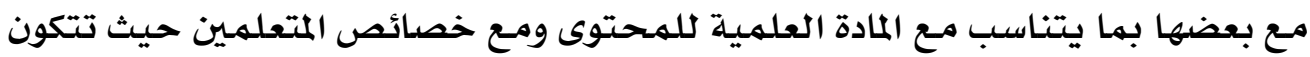

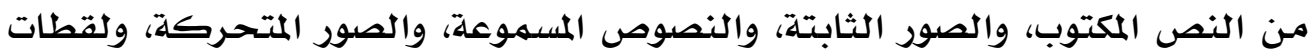

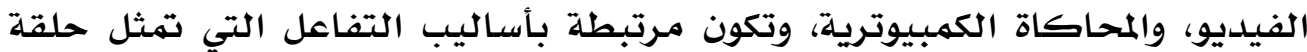

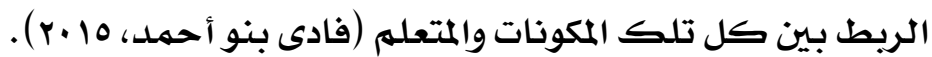

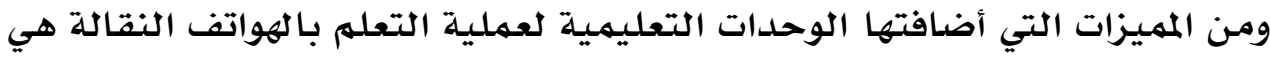

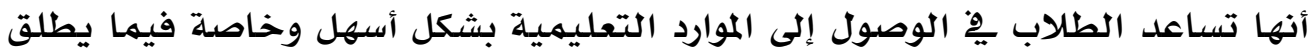

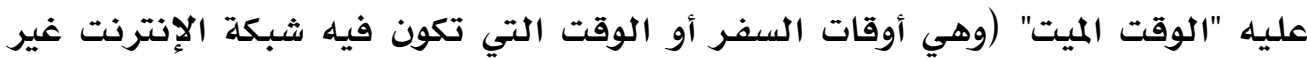

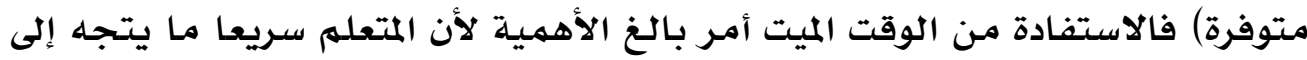

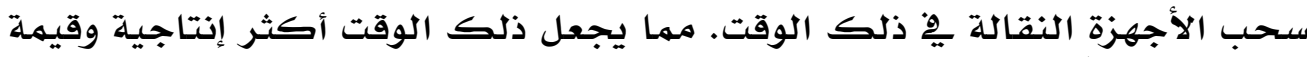

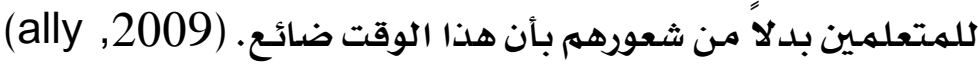


ويري (Bradley,2005) أنه عند تصميه الكائنات التعليمية من أجل الهواتف

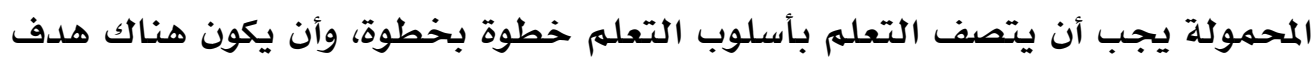

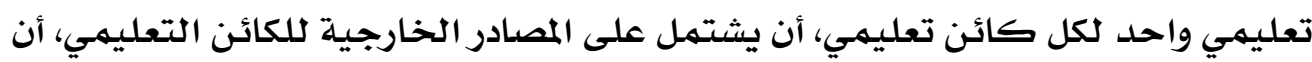
يكون هناك مجموعة من المراجع الخارجية للهدف لكول التعليمي.

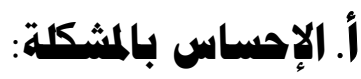
نبع الإحساس بمشكلة البحث من خلال: أولاً تتائج وتوصيات الدراسات السابقة:

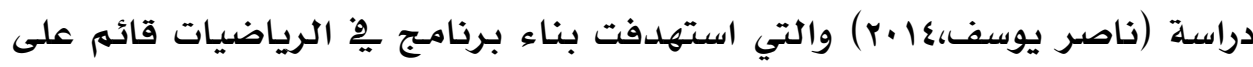

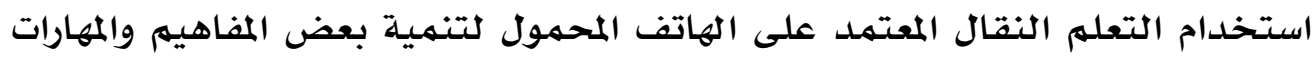

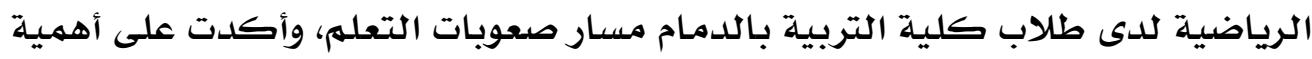

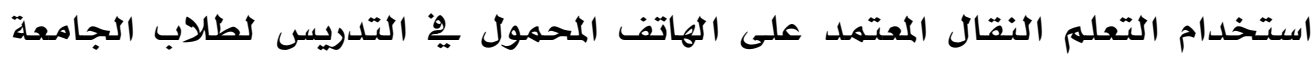

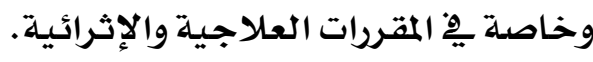

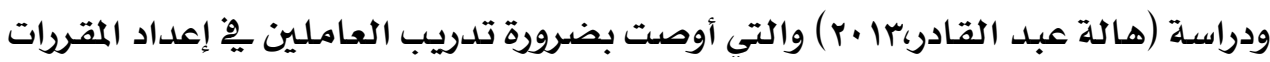

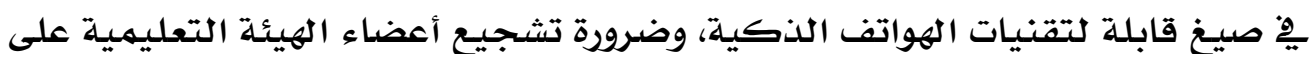

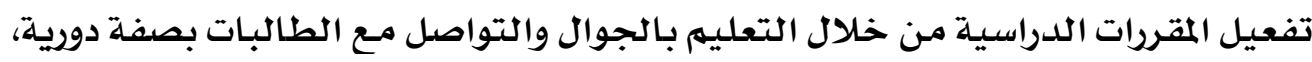

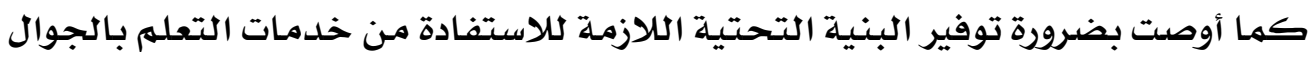

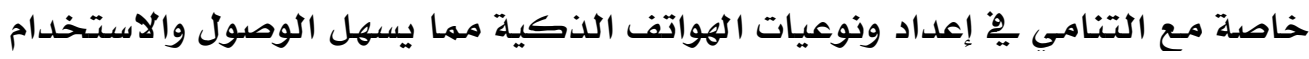

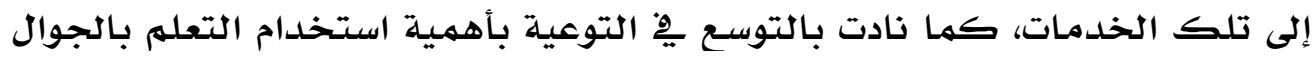
وفوائده التربوية للطلاب.

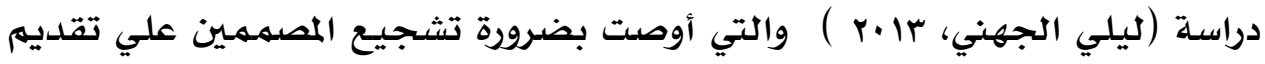

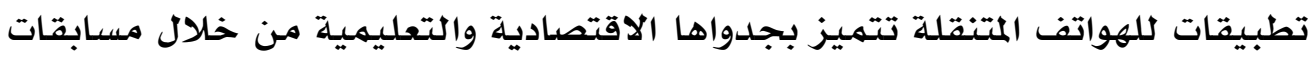

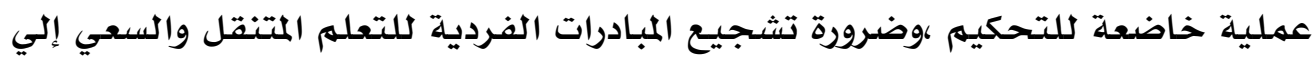

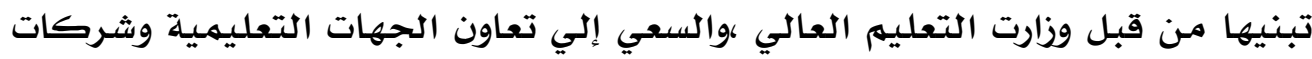

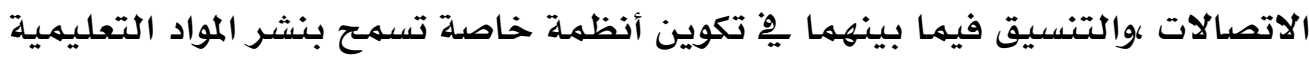

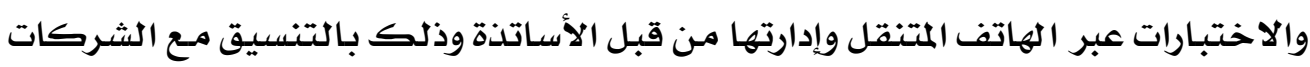

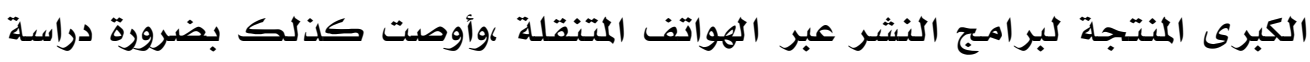
معايير تصميم تطبيقات التعلم المتنقل. دراسة ( ) 2009 , Haiguang) وهدفت هذه الدراسة إلى بناء بيئة تعلهم تكيفيه 
ومنصدة لمصادر التعلهم النقال باستخدام وحدات العناصر التعليمية وتم بناء هذا النموذج النعاد

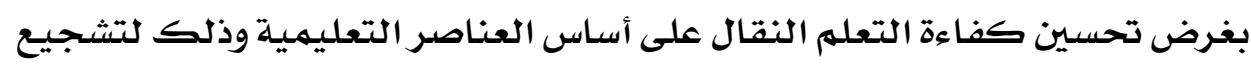
التعلهم مدي الحياة وبناء المجتمهـع المتعلهم.

دراسة (2010, Madjarov\& Boucelma) التي هدفت إلى التعرف على فاعلية

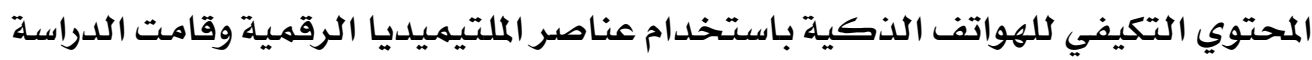

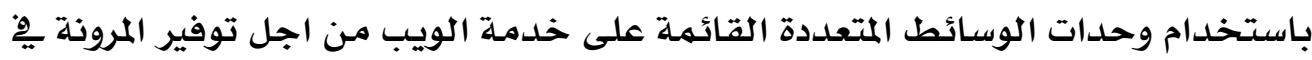

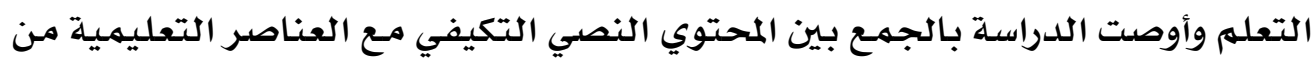

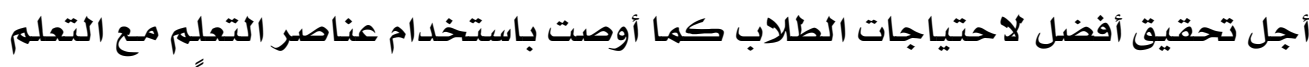

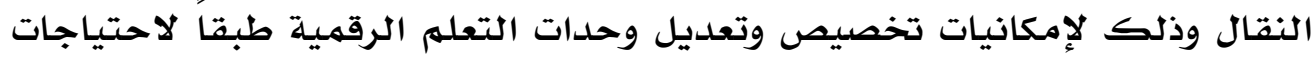

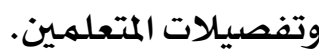

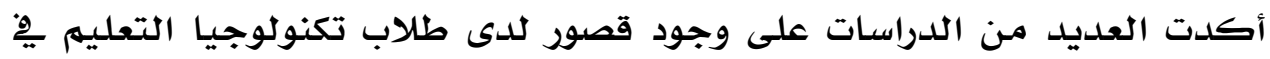

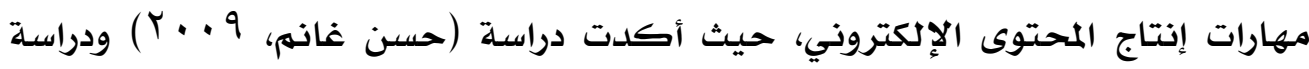

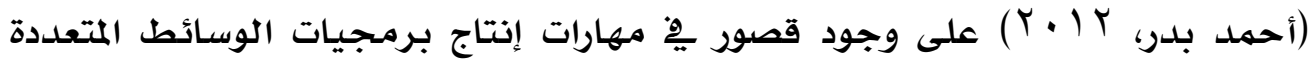

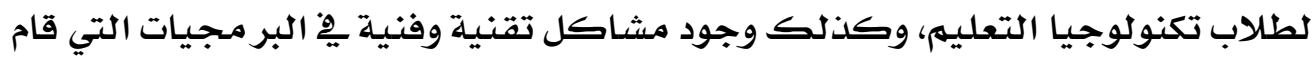

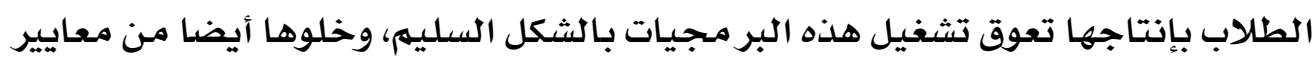

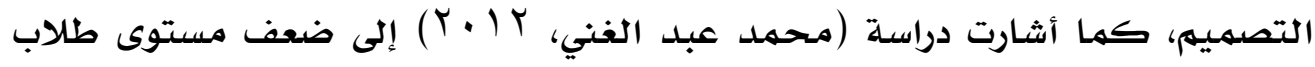

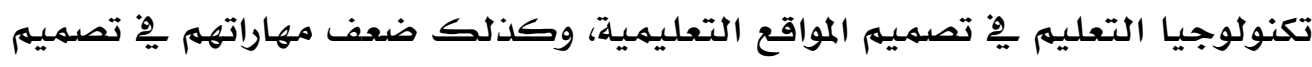

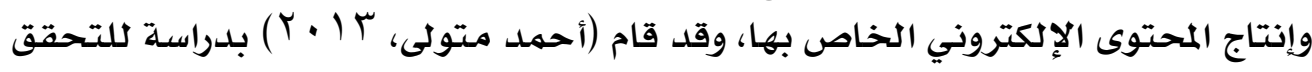

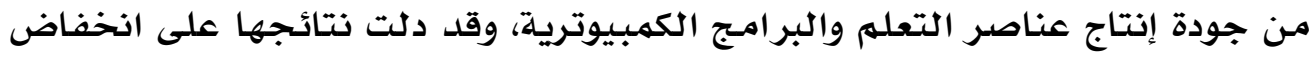

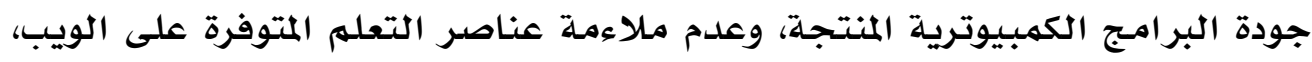
حيث أنها غير مطابقة للمعايير التربوية و التقنية.

ودراسة (محمد عفيفى،با ·r) والتي بحثت أثر اختلاف نهط توظيف خرائط المفاهيم

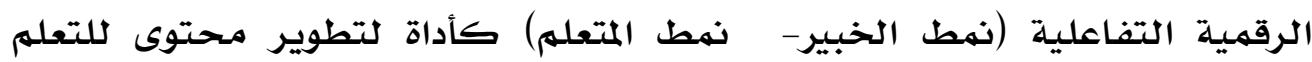

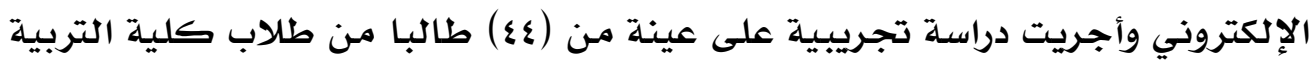

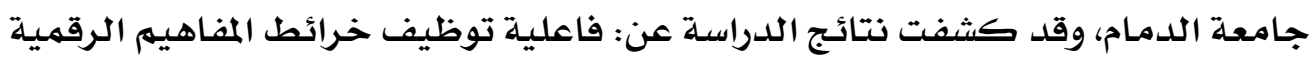

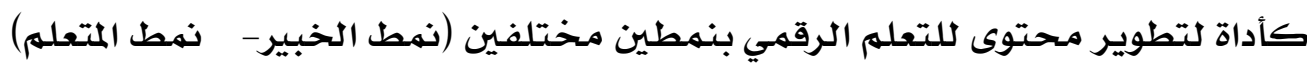

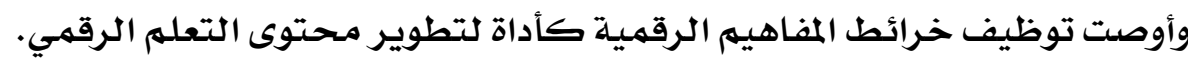

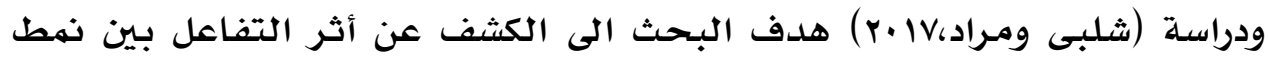

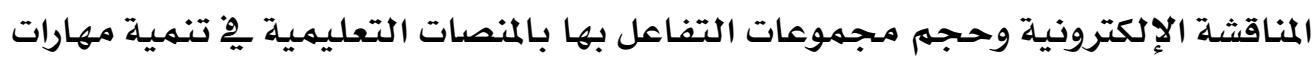




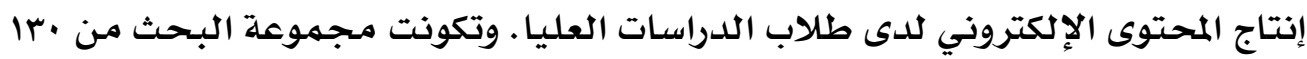

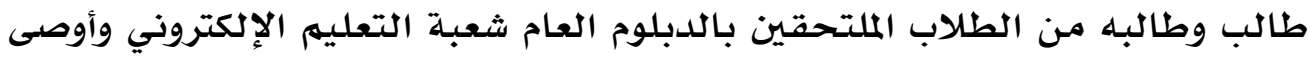

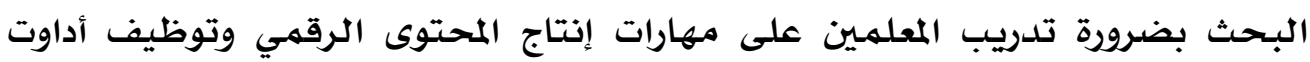
المناقشات.

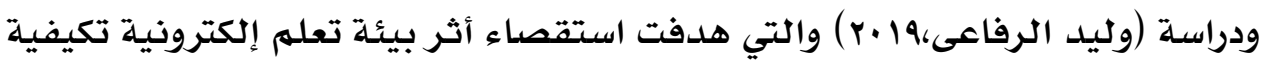

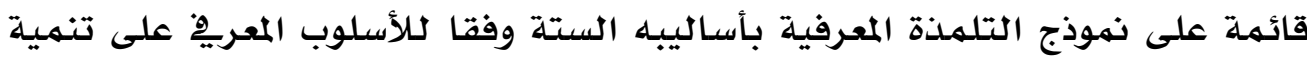
مهارات إنتاج المحتوى الرقهي لدى طلاب تقنيات التعليه، طبق البـحث على عينـة قوامها

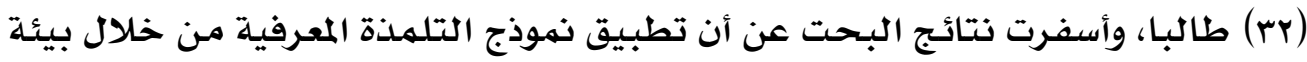

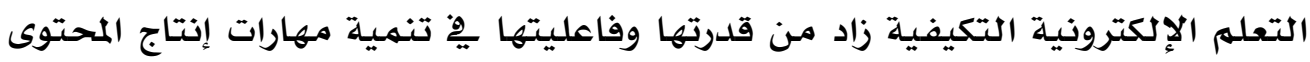
الرقهي. وفى ضوء نتائج وتوصيات الدراسـات السـابقة يتضدح ان هناك ضرورة لتتهمية مهارات انتاج

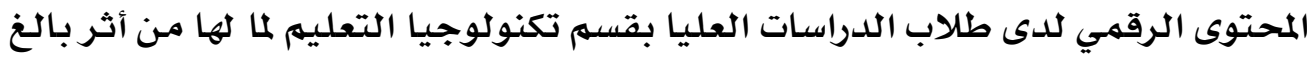
يِّ انتاج تطبيقات للهواتف الذكية تهتاز بجدواها التعليمية والاقتصدادية. ثانياً: القيام بلدراسة استكشافية تثثلت في:

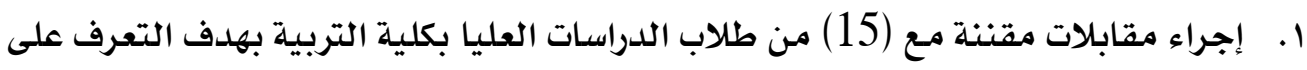

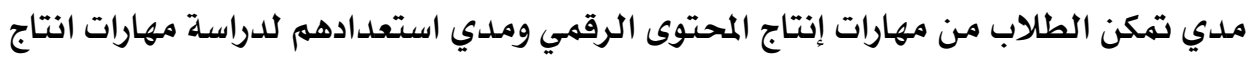

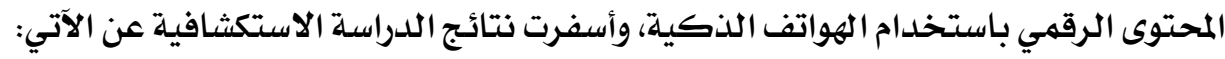

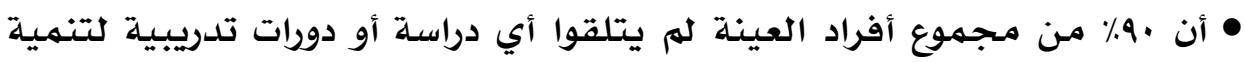
مهارات انتاج المحتوى الرقهي.

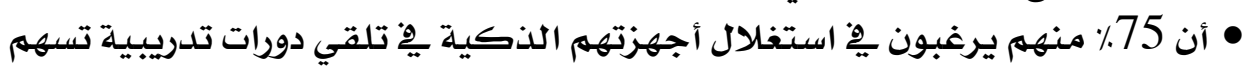

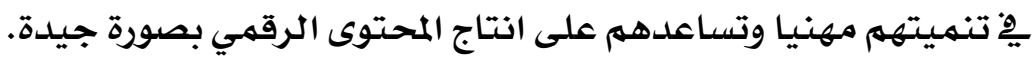

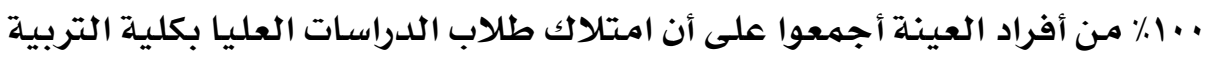
لمهارات انتاج المحتوى الرقهي له أهمية كبية اديرة.

في ضوء خبرة الباحث ونتائج الدراسـات السابقة ونتائج الدراسـة الاستكشافية يتضـح

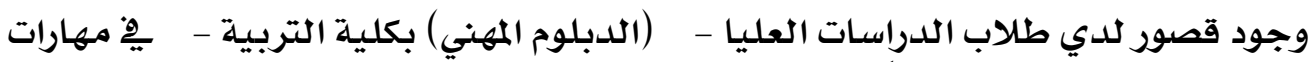

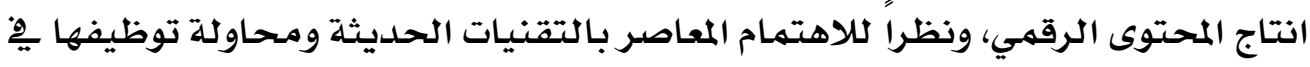


خدمـة العملية التعليهية وحاجة الأنظمة التعليمة إلى تقديهم الحلول لبعض المثكلات

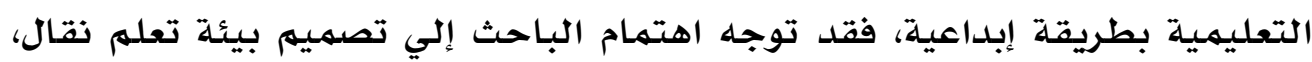

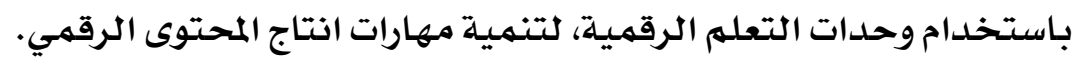
ولذا يتطلب البحث الحالي صياغة السؤال الرئيسي التالى:

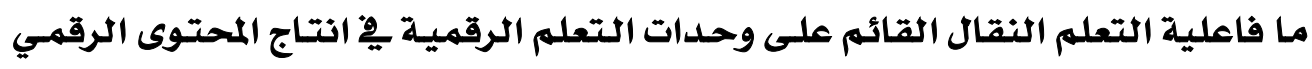
لدي طلاب الدراسات العليا بكلية التربية؟ ويتفرع من هذا السؤال الأسئلة التالية: ا- مـا مهارات تصميهم وإنتاج المحتوى الرقهي الواجب توافرها لدي طلاب الدراسات

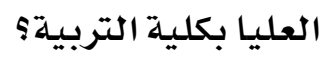

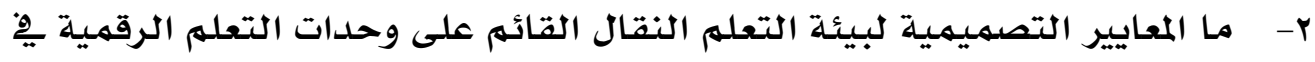

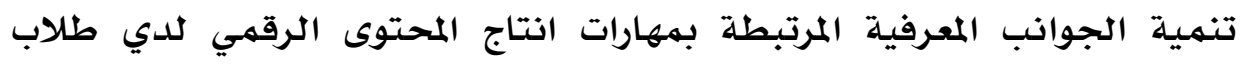

$$
\text { الدراسات العليا بكلية التربية الموانية }
$$

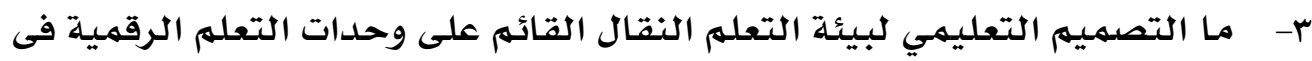
تنميـة مهارات انتاج محتوى التعلهم النقال لدى طلاب الدراسـات العليا بكلية التربية

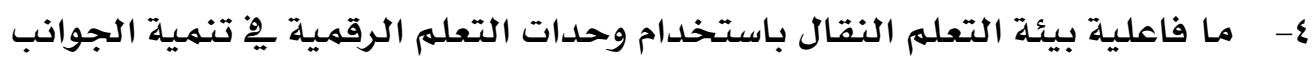

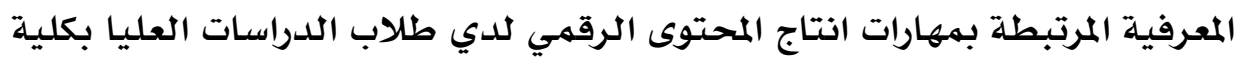

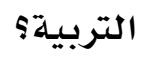

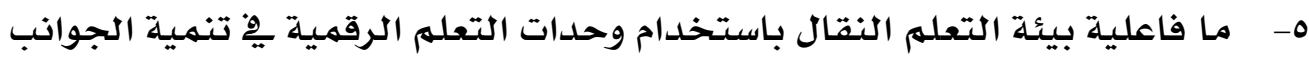

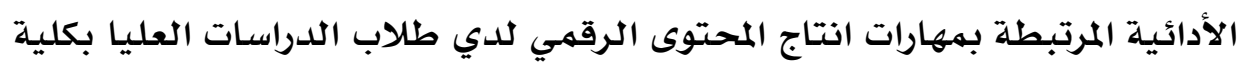

التربية الادانه

צ- ما فاعلية بيئة التعلهم النقال باستخدام عناصر التعلهم الرقمية علي جودة المنتج

$$
\begin{aligned}
& \text { النهائي؟ } \\
& \text { أهد|ف البحث: أهمان }
\end{aligned}
$$

هدف البحث الحالي إلي تنمية مهارات انتاج محتوى التعلم النقال وذلك من خلال: 
1- الكثف عن فاعلية بيئة التعلهم النقال القائم على وحدات التعلهم الرقهية على الجـانب المعربِ المرتبط بههارات انتاج المحتوى الرقهي لدي طلاب الدراسـات العليا

$$
\text { بكلية التربية }
$$

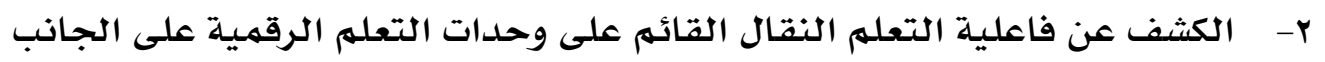
الأدائي المرتبط بههارات انتاج المحتوى الرقهي لدي طلاب الدراسـات العليا بكلية التربية الاددية

r- الكثف عن فاعلية بيئة التعلهم الرقهية القائم على وحدات التعلهم الرقهية علي جودة المنتج النهائي.

\section{تمثلت أهمية البحث الحالي فيما يلي:}

ا- تفيد هذه الدراسـة طلاب الدراسـات العليا بكلية التربية من انتاج محتوى رقمى متتوافق مـع الهواتف الذكية وملائمة تربويا وتقنيا.

ץ- - تقدم هذه الدراسة آلية مقترحة لاستخدام التعلم النقال ِِّ خدمة التعليم عامـة، والتعليم الجامعي بصورة خاصة.

ץ- - تقلدم حلول لفئة من المجتهـع لا تمكنهم ظروفهم من مواصلة دراستهم الجامعية بنظام الانتظام.

ع- تفيد هذه الدراسة مطوري ومصهمى المواد والتطبيقات التعليمية والتدريبية ِِّ إنتاج تطبيقات ملائمة تربويا وتقنيا.

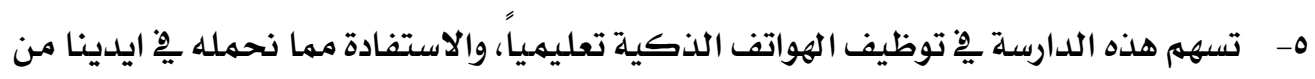

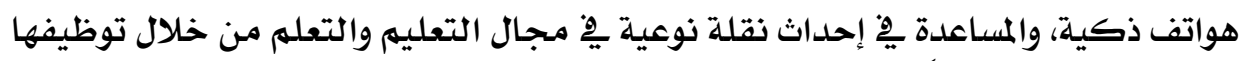

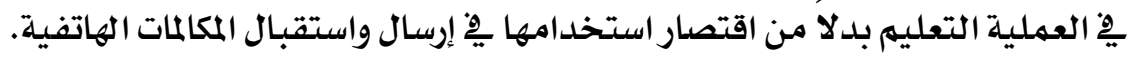

\section{عينة البمث:}

عينة من طلاب الدبلوم الخاص شعبة تكنولوجيا التعليم وعددهم(بr) طالب ِِِ العام

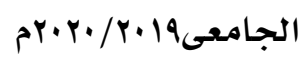




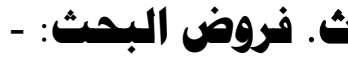

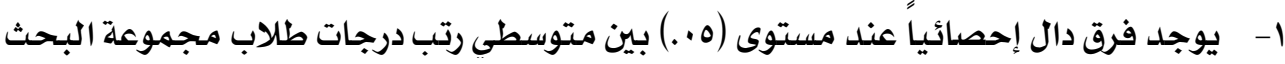

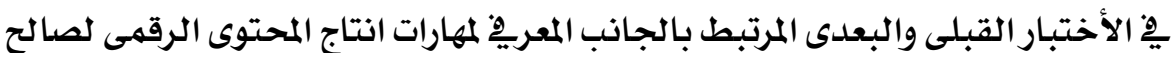

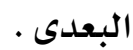
r- - يوجد فرق دال إحصائياً عند مستوى (ه . .) بين متوسطى رتب درجات كسب طلاب مجموعة

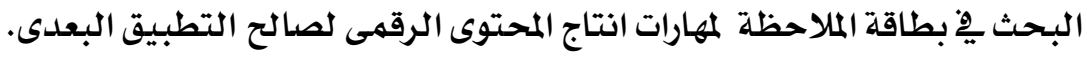

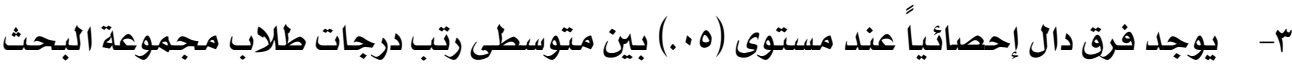
مِّْ بطاقة تقييم جودة المنتج النهائي.

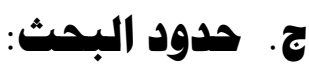
تمثلت حدود البحث الحالي فيما يلي: ا- عينة من طلاب الدراسات العليا شعبة تكنولوجيا التعليم بكلية التربية جامعة المنصورة بقسم

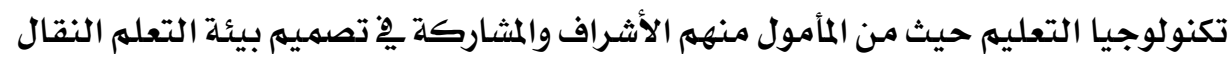

$$
\text { لأغراض تعليمية وتربوية. }
$$

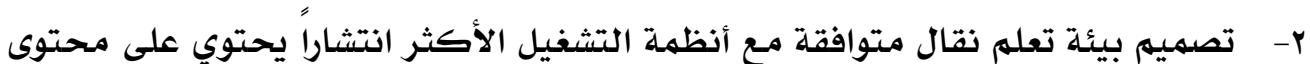

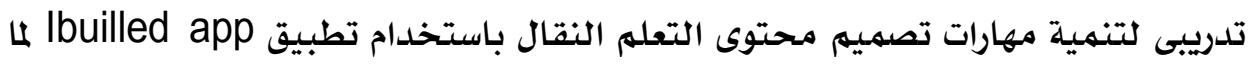

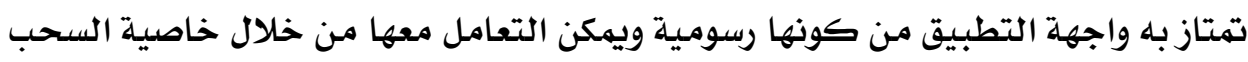

$$
\text { والإفلات بلدون كود برمجية. }
$$

r- سيتم توظيف بعض التطبيقات المساعدة الخاصة بالحوسبة السحابية (Google drive)

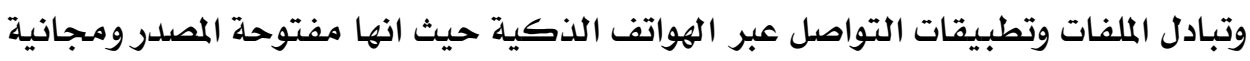
لجميع الطلاب.

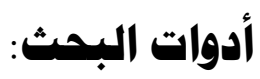

استخدم البحث الحالي الأدوات التالية : لمالية ا- أداوت جمـع البيانات:

مقابلات مقننة مـع مجموعة من طلاب الدراسات العليا بكلية التربية. 


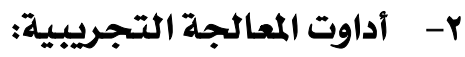

بيئة التعلهم النقال القائم على وحدات التعلهم الرقميـة.

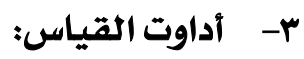

أختبار تحصيلى لقياس الجوانب المعرفية المرتبطة بههارات انتاج المحتوى

$$
\text { الرقهى. }
$$

بطاقة ملاحظة لقياس الجوانب الادائية لأداء مهارات انتاج المحتوى الرقهى.

بطاقة تقييهم للهنتج النهائي.

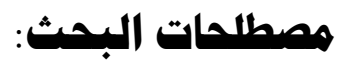

اشتمل البحث على المصطلحات التالية:

وحدات التعلم الرقمية:

ويعرفها الباحث إجرائيا بأنها : مـجموعة من المصادر الرقمية التي يهكن انتاجها وإعادة

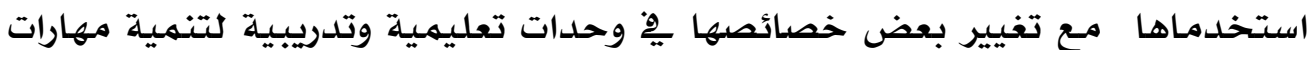
تصميهم وإنتاج المحتوى الرقهى.

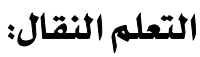

يعرف الباحث التعلهم النقال بأنه : "هو ما يتتم تقديمه لطلاب الدراسات العليا بكلية التربية ضهن عملية تعليمية وتدريبية باستخدام الأجهزة النقالة لتنمية مهارات تصميهم وإنتاج المحتوى الرقهى"

\section{الإطار النظري للبحث}

التعلم النقال الثائم على وحدات التعلم الرقمية

تعتبر ثورة التعلهم بالهاتف النقال إحدى التجارب الحديثة التي تحاول مؤسسـات التعليهم العالي الاستفادة منها ِيخ تحسين وتطوير العملية التعليمية لدى الطلاب والطالبـات،

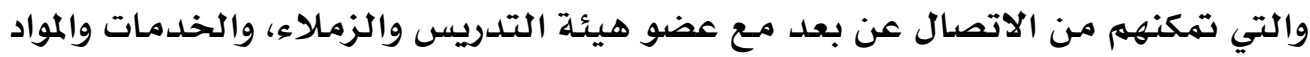

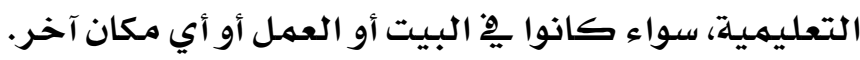




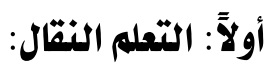

يعرف (محمد أحمدهم|.r) التعلم النقال بأنه: طريقة التعليم والتعلهم تستخدم فيها

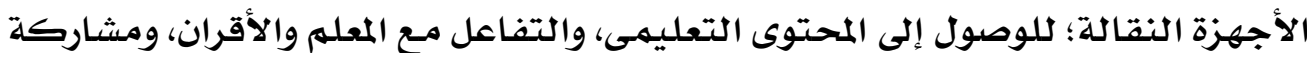

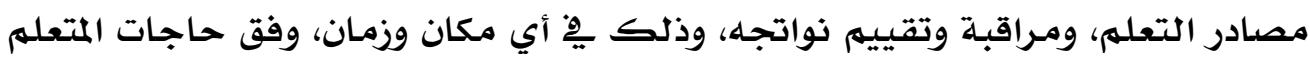
وظروفه، داخل المؤسسة التعليمية أو خارجها.

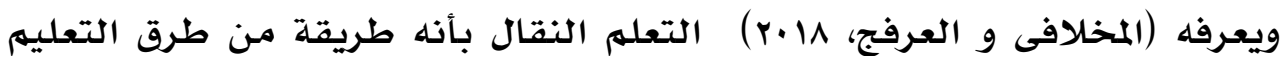

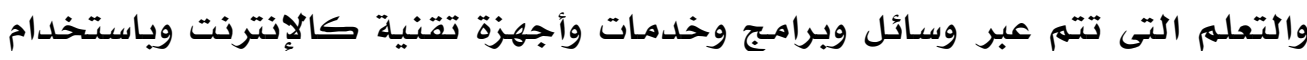

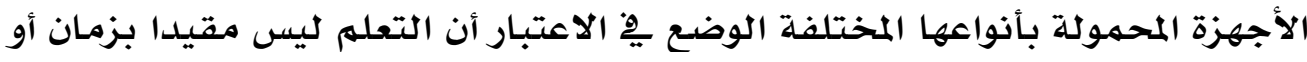
مكان.

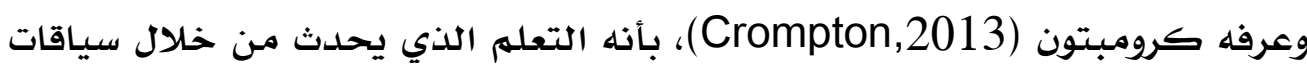

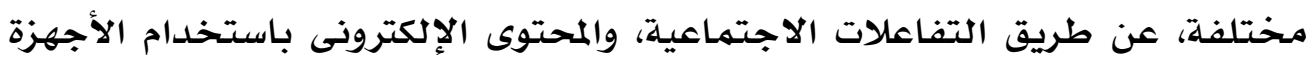
الإلكترونية الشخصية.

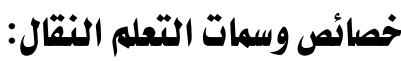

يتميز التعلم النقال بعدد من الخصائص، والتي حددها خميس (10 •r)، هِّ النقاط

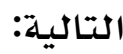

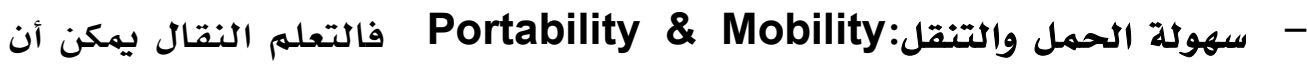

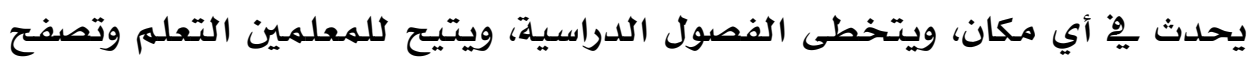

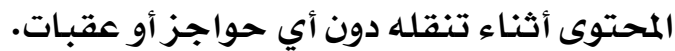

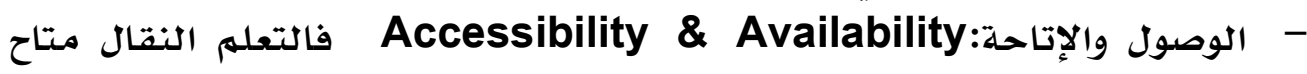

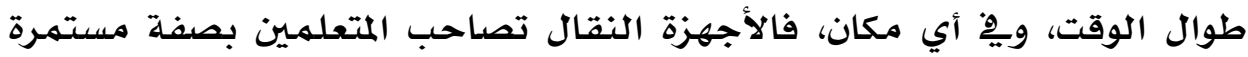

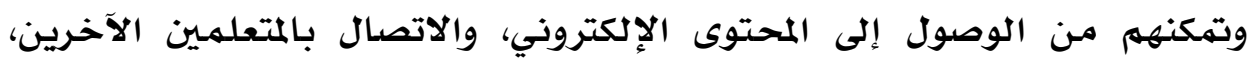

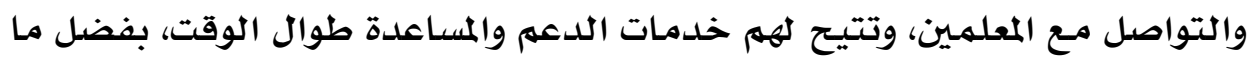

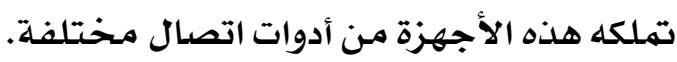

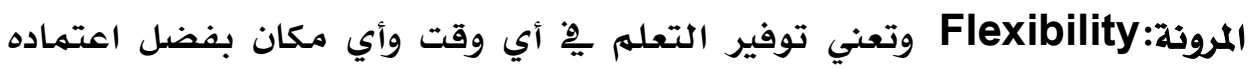

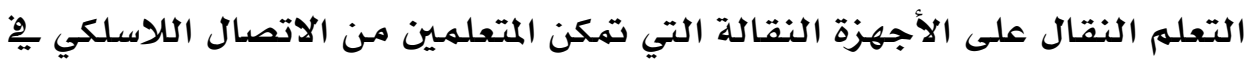

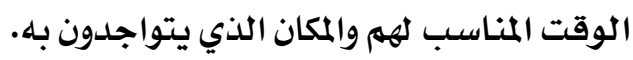

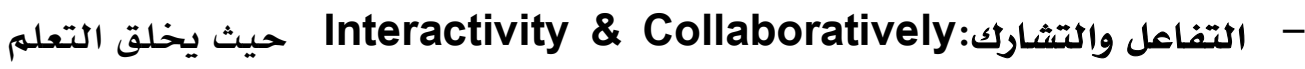
النقال بيئة تعلهم جديدة، ومواقف تعليمية متنوعة تقوم على أساس التفاعل

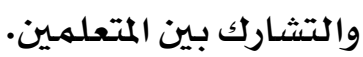


- التكيف:Adaptability فالتعلهم النقال تعله تكيفي، فهو يتكيف مـع حاجات المتعلمين المختلفة.

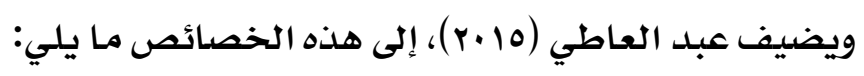

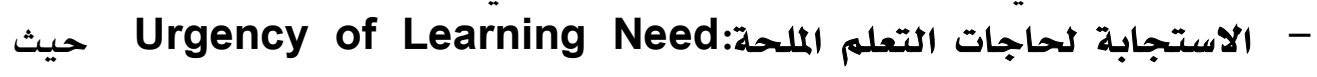

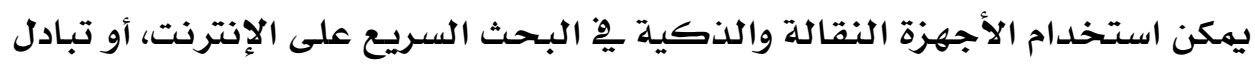

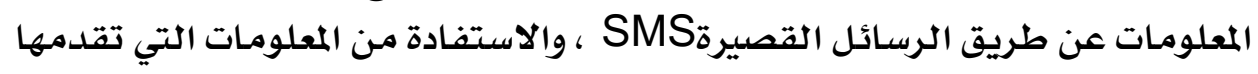

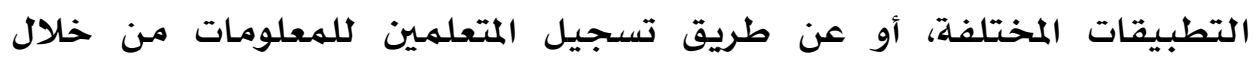
التطبيقات المختلفة.

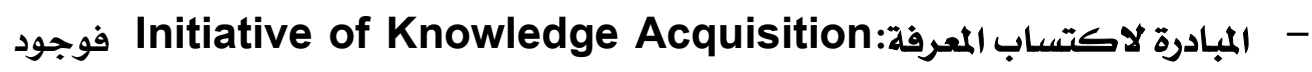
الهاتف النقال ِِّ يد المتعله يكون له دور أساسي يِّ مبادرته للحصول على المعارف والمعلومات.

Situating of Instructional النشاط التعليمي المبني على المواقف Activity:

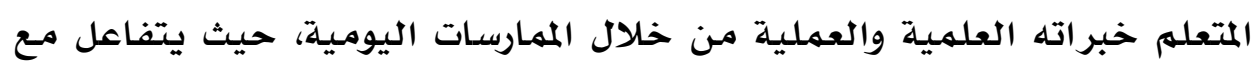

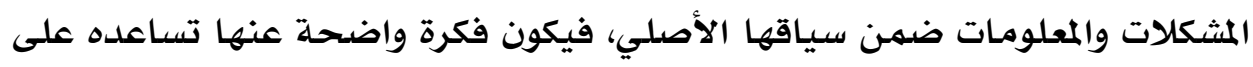

$$
\text { إيجاد حلول واقعية ومناسبة. }
$$

ويرى الباحث أن خاصية التنقل Mobility هي الخاصية الأهم التي يتميز بها التهادية التعلم

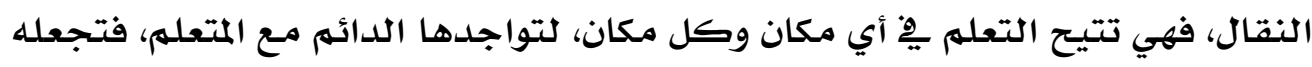

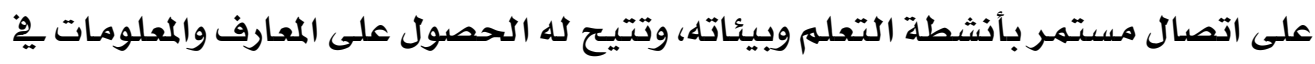
أي مكان بسهولة وسرعة. فوائل وميزات التعلم النقال:

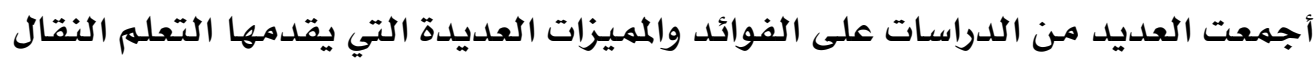

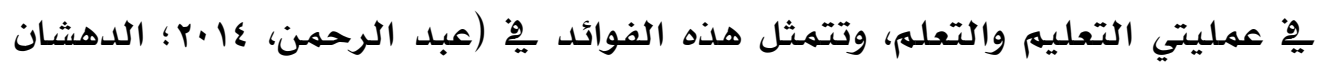

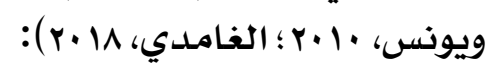

يحقق مفهوم التعلهم الفردي الذي يحدث ِِّ كل مكان وزمان، وفقا للحاجات الشخصية للمتعلهم.

يجعل بيئة المتعلهم هي البيئة الحقيقية للتعله. يسهل التعاون والدعم من خلال الاتصال المتززامن والغير متتزامن، ممـا يساعد على بلى 


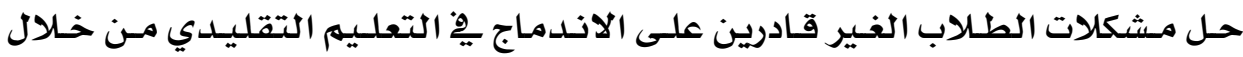

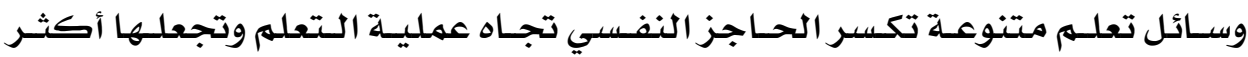
جاذبية.

يساعد على إضافة المزيد من الأنشطة إلى الدروس التقليدية مما يحقق الحيوية،

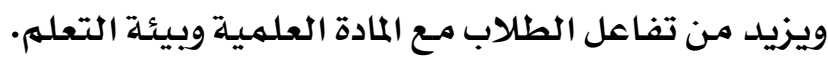

يساعد الطلاب على إنشاء وتبادل المحتوى الخاص بهم، ويحسن من مهارات الكتابة

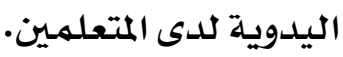

يستوعب أعداداً كبيرة من المتعلمين، ويتيح فرص التعلم للطلاب الذين يسكنون بعيدا عن أماكن تعلمهم. يمكن تحديث محتواه وتطبيقاته بسهولة ويصورة مستمرة. يعزز استخدام الثقافة الرقمية لدى المتعلمين. يهكن أن يستخدم كتقنية مساعدة للمتعلمين الذين يواجهون صعوبات التعله.

ثانياً: وحدات التعلم الرقمية:

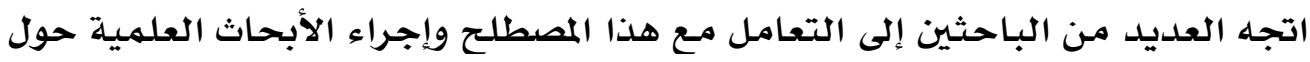

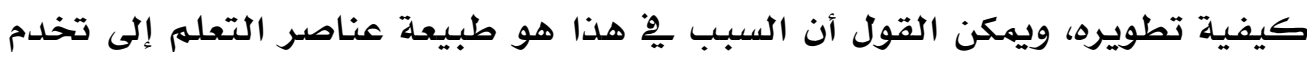
جميع المجتمعات على اختلاوف الثقافات واللغات.

\section{مفهوم وحدات التعلم الرقمية:}

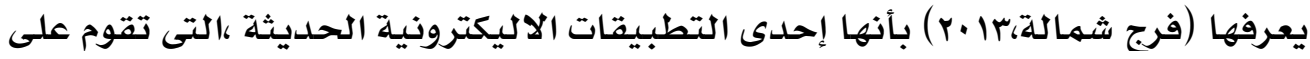

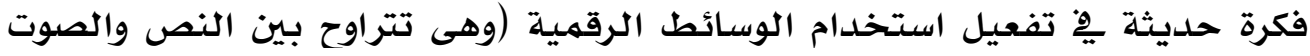

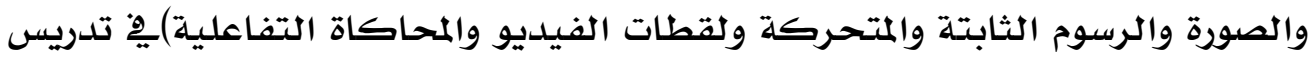

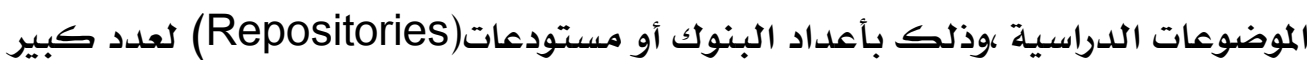

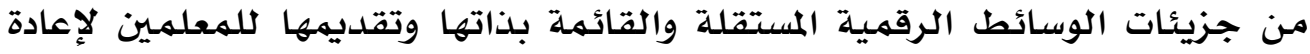

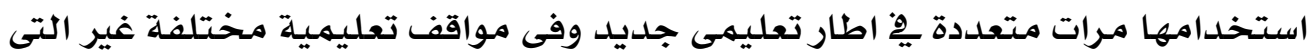

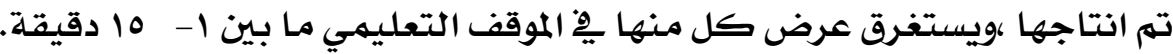

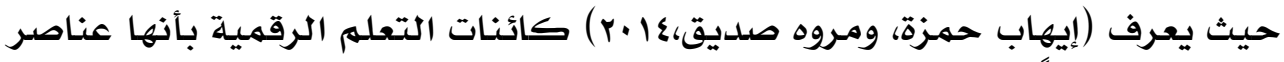

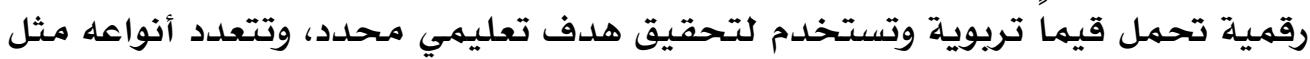


صوت، فيديو، صورة متحركة، صورة بيانية، رسوم ثابتة ومتحركة وتتاح هذه العناصر

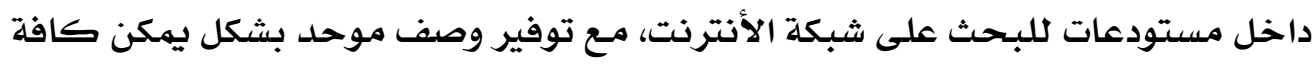

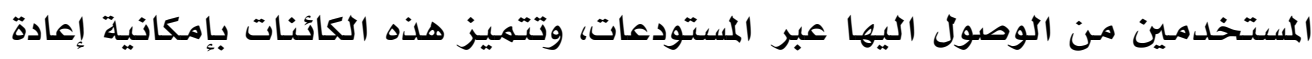
استخدامها يْ أكثر من محتوى تعليهي.

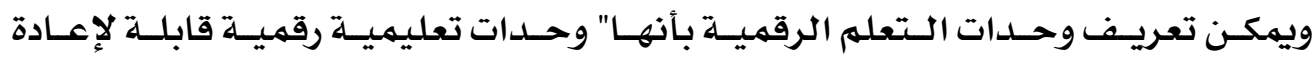

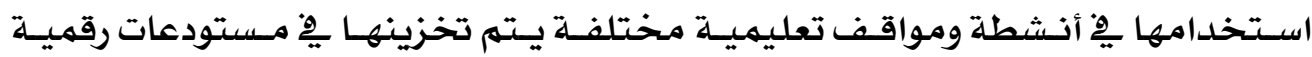

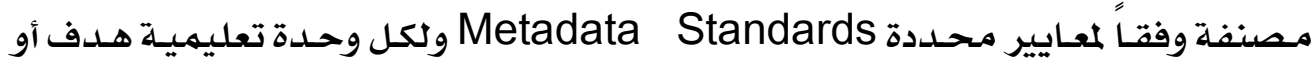
مجموعة من الأهداف مححددة".

\section{خصائص وحلدات التعلم الرقمية:}

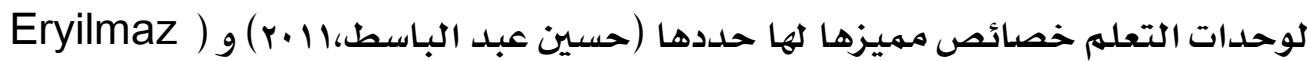

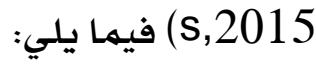
تتكون وحدات التعلهم الرقمية من مجموعة عناصر كالصوت والصور والفيديو والرسومات والخرائط والرسوم المتحركة وغيرها بما بضا يضفي على المواقف التعليمية

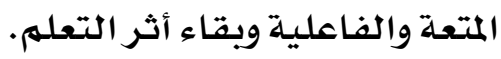
القابلية للتداول والتبادل على كافية نظمى التشغيل.

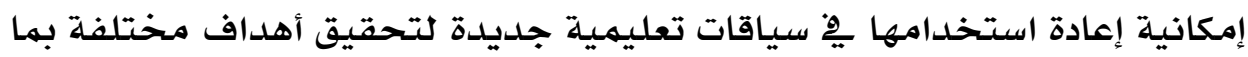

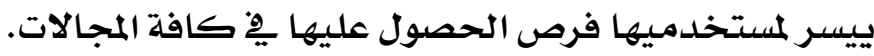
سهولة الوصول من خلال شبكة الأنترنت مـع إمكانية البحث والاسترجاع الماع بها يوفا يوفر نفقات الشراء والإنتاج لمستخدمئهيها.

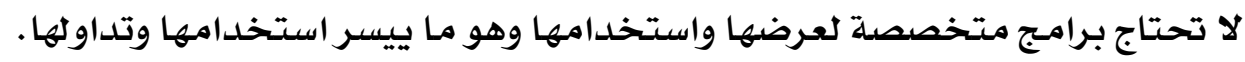
تنوع محتواها واعتمادها على الحواس المختلفة للمتعلمـين يجعلها الأنسب لمراعاة الفروق الفردية بـين المتعلهـين.

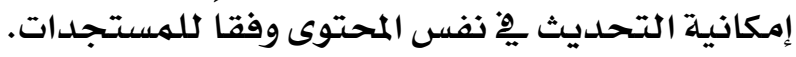
صغر الحجم حيث تتسهم وحدات التعلهم الرقمية بصغر حجمها لتركز اهتمام

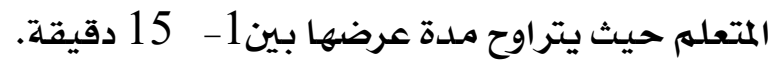

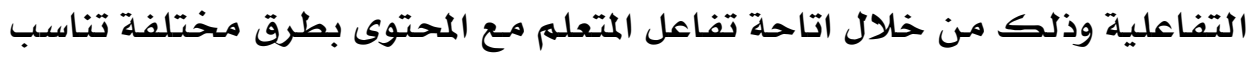
الفئة المستهدفة ومستواها العمـري والعقلي.

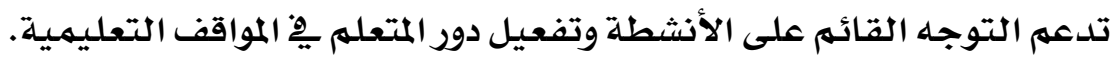




\section{مميزات وحدات التعلم الرقمية في بناء وتصميم محتوى التعلم:}

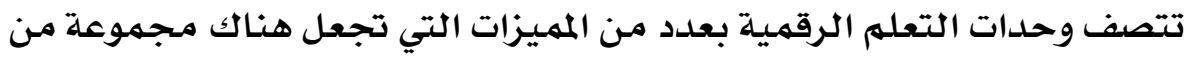

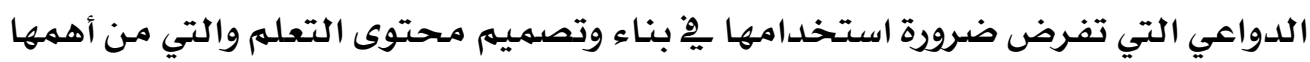

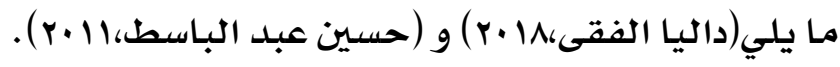
1- إ- توفير التكلفة والبدائل:

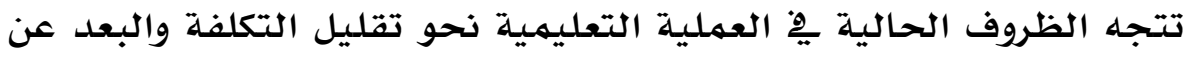

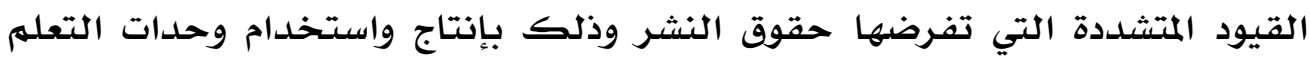

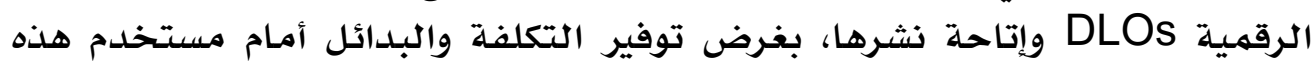

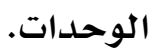

r- ب تشجيع المنافسة:

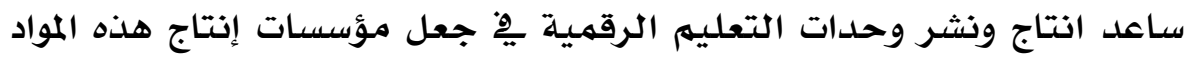

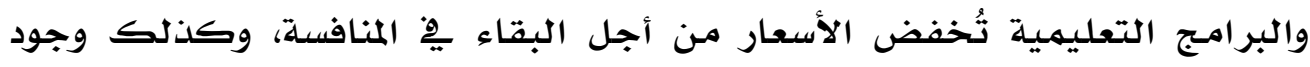

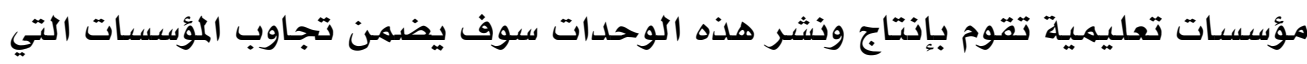

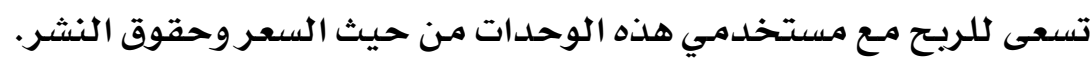

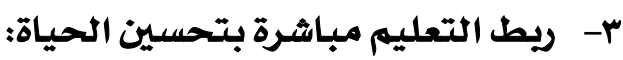

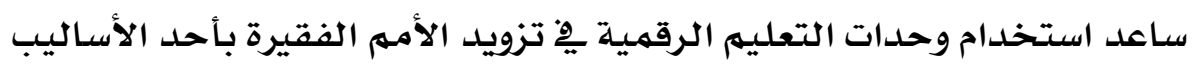

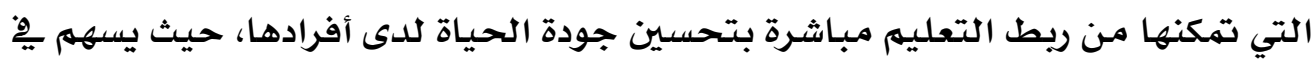

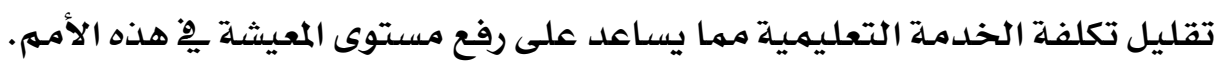
ع- تحقيق القيمة الحقيقية من التعليه:

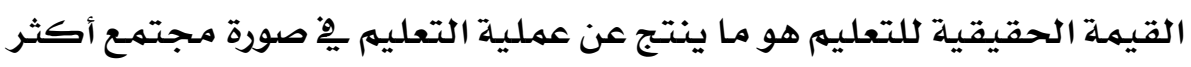

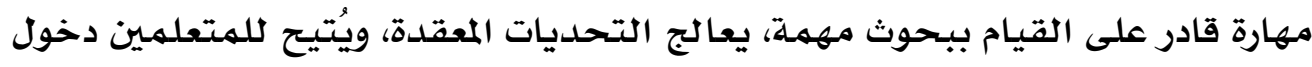

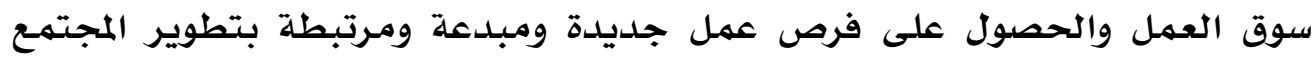
وتحسين أوجه الحياة لديه والهمول

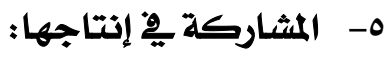

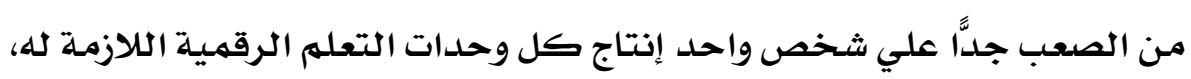

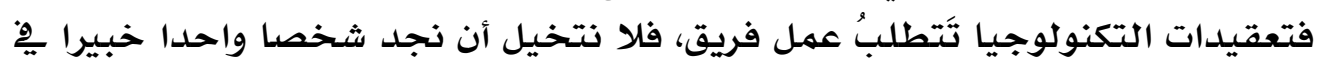




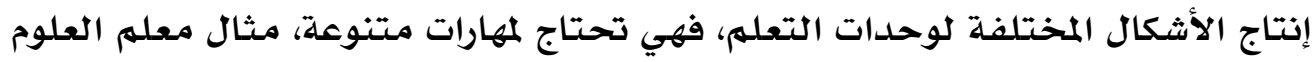

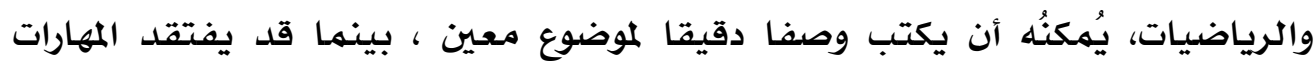

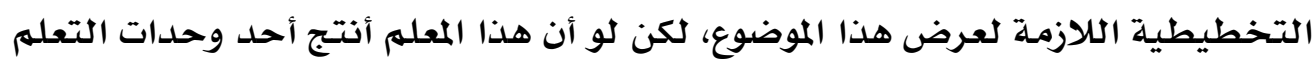

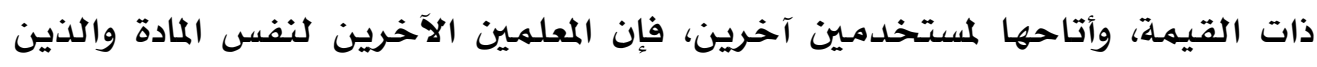

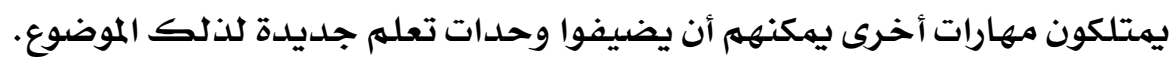

\section{أنفاط وحدات التعلم الرقمية:}

هناك أنماط متنوعة لتقديم المحتوى التعليهي من خلال وحدات التحات التعله

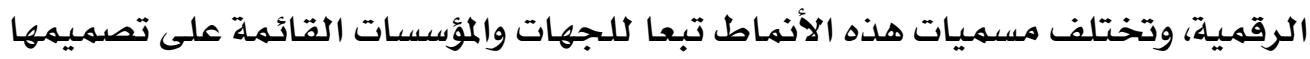

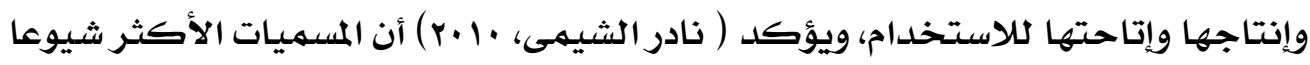

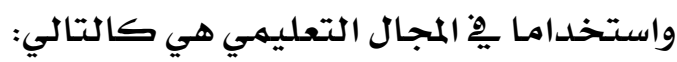
I. Step: وتطلق على اصغر كيان تعليمي متكامل، يتضمن كافة مكونات

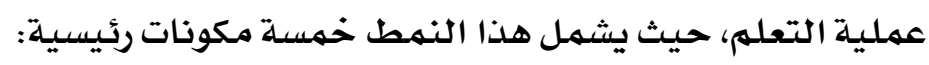

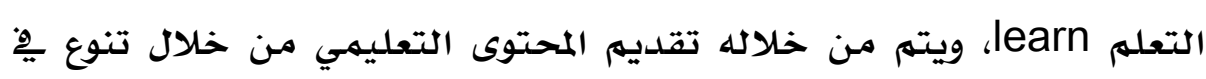

$$
\text { الوسائط المستخدمة (وسائط سمعية، مرئية، ....) }
$$

• الأنشطة Activities، ويتهم من خلالها تقديه عدد من الأنشطة التفاعلية

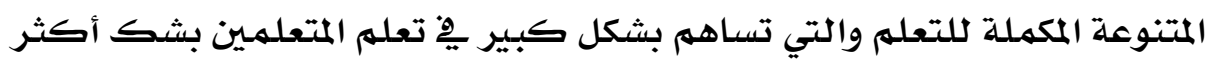

عمقا.

التقييم الذاتي Self-Assessment، يته من خلاله تقديه عدد من الأسئلة الموضوعية، مـع مراعاة تقديم تغذية راجعة مباشرة وفورية وموجهة.

قاموس المصطلحات Glossary، ويتضمن قائمة بالمصطلحات التي تم عرضها

$$
\text { بالمحتوى التعليهي مرتب أبجديا. }
$$

الملخص Summary، ويقدم ملخصا وافيا لما تم عرضده بالمحتوى التعليهي.

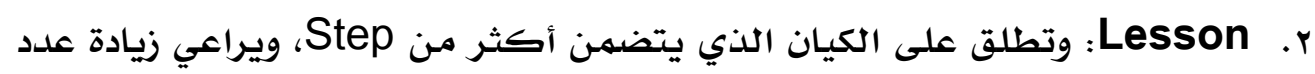

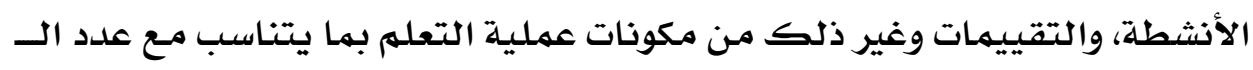
Steps

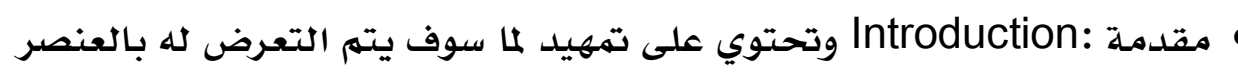




\section{التعلهي.}

الدرس Lesson: والذي يقدم المحتوى التعليمي من خلال جرعة مكثفة من

الوسائط المتعددة.

الملخص Summary: ويقدم ملخصا وافيا لما تم عرضه بالمحتوى التعليمي. قاموس المصطلحات Glossary : ويتضمن قائمة بالمصطلحات التي تم العرض لها بالمحتوى التعليهي لعنصر التعلهم.

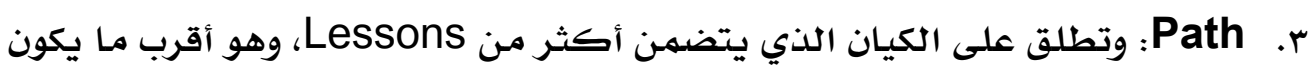

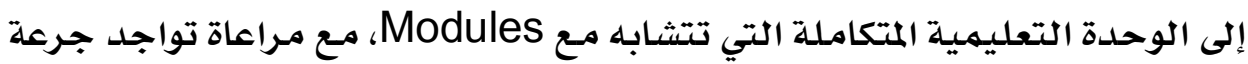

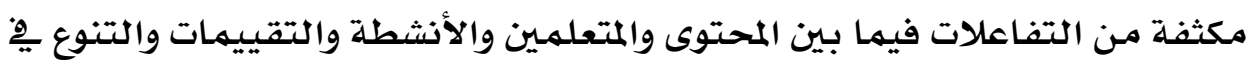

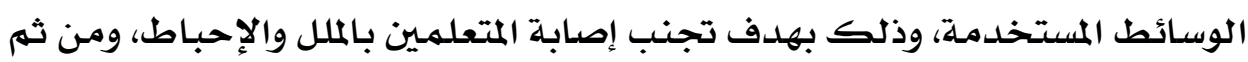

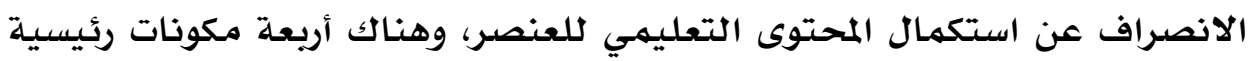
بهذا النمط:

التعلم Learn، والتي يتهم من خلالها استعراض المحتوى التعليمي Lessons. المستكشف Explorer، والذي يقدم محاكاة افتراضية تفاعلية ذات علاقة بأحد التطبيقات العملية للمحتوى التعليمي.

التقييمات Assessments، وتشمل عدد كبير من الأسئلة مـع تقديم تغذية راجعة موجهة. قراءات إثرائية Relate، وتتضهن مجمهوعة عريضة من القراءات الإثرائية ذات العلاقة بالأهداف التعليمية للعنصر التعليمي.

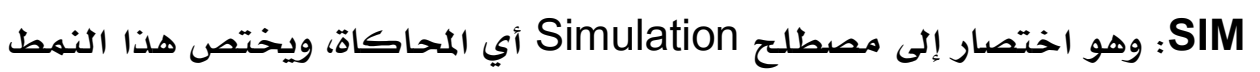

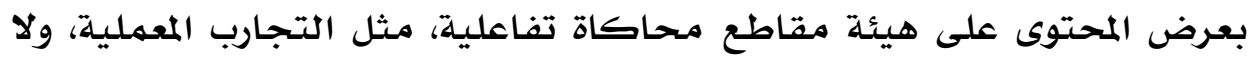

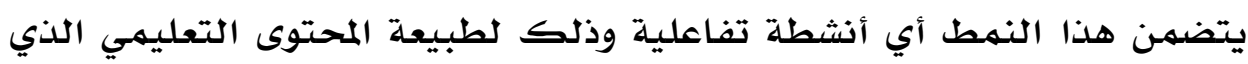

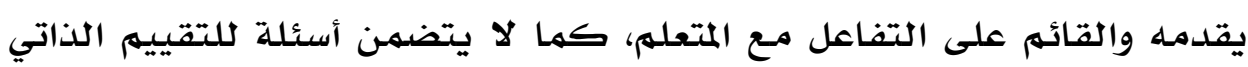

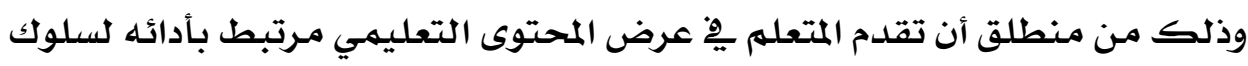

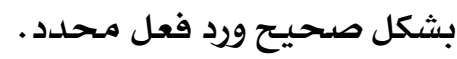




\section{ثالثاً: اتتاج المحتوى الرقمي:}

يعرف (فادى بنو أحمد وآخرون، 10 ب ) المحتوى الرقهي بأنه النسخة الرقهية للهحتوى

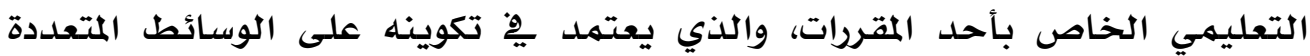
(نصوص، وصور، وكائنات صوتية ومـرئية) مـن خلال موقع على شبكة الإنترنت، ويضهم

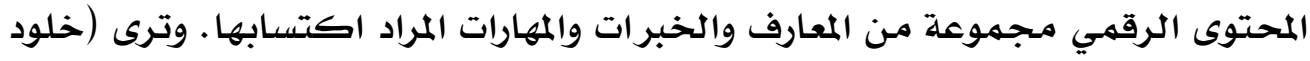

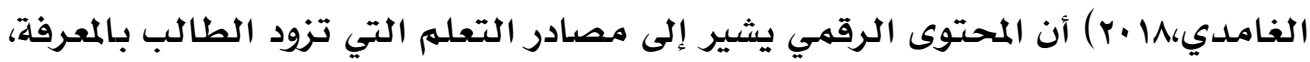
وتم تصهيهها وتقديهها بشكل رقهي مدعم بـالوسائط المتعددة، يتيح للطالب التفاعل

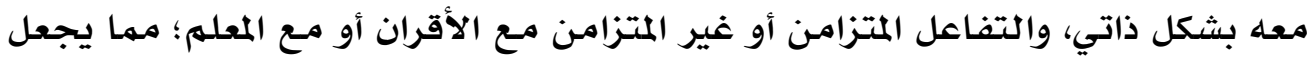
الطالب نشط يِّا البحث عن المعلومة سعيا لتحقيق الأهداف التعليمية المنشودة.

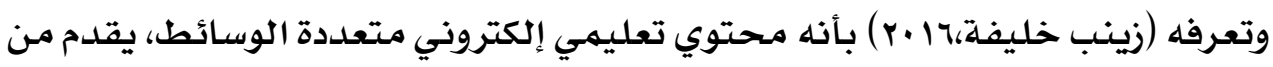

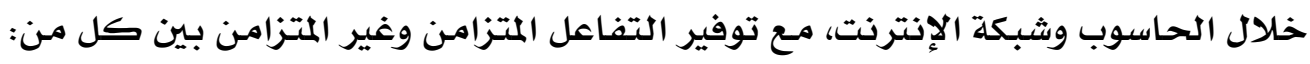

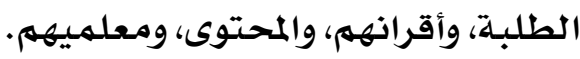

ويعرفه الباحث بأنه" مجمموعة من عناصر التعلهم تم اعداداها بصورة رقمية مدعومة

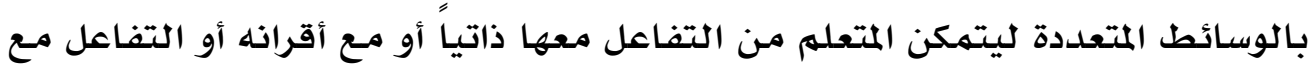

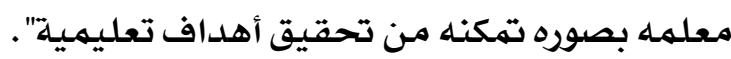

ومن خلال الأدبيات والدراسـات التي تناولت المحتوى الرقهي يهكن استخلاص أهم

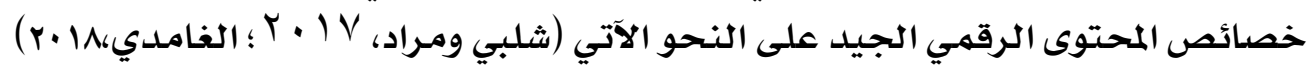

• التمثيل الصادق للواقع: فجودة المحتوى ترتبط بمدى ودقة تهثيله للواقع.

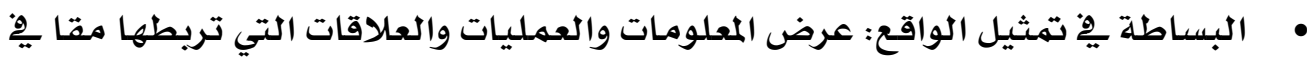

$$
\text { صورة مبسطة. }
$$

• النظامية: هِ عرض المعلومات فِ شكل تدرج وتسلسل منظم للتيسير فهمها وتفسيرها.

• الشرح: شـرح المحتوى للموضوعات بطريقة يسهل على الطالب فهمها. "الاتساق الداخلي: اتسـاق جميع عناصر المحتوى مـا دون ازدواجية أو تعارض.

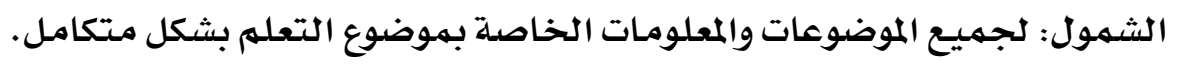

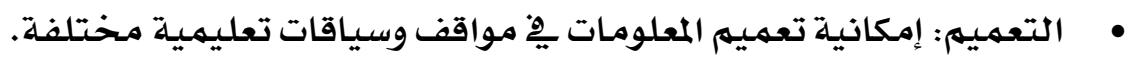

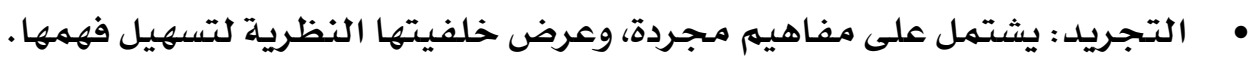

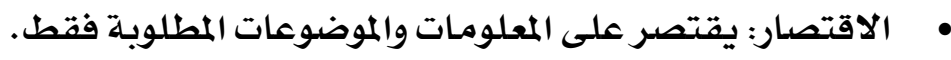


التحديد الواضح: لمواصفاته وشروطه ومتطلبات استخدامهـ.

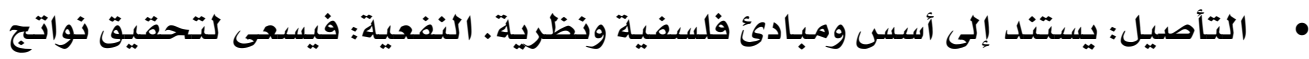
من شأنها زيادة فاعلية وكفاءة التعله.

\section{مهارات إنتاج المحتوى الرقمي: - من}

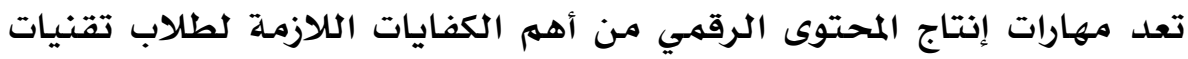

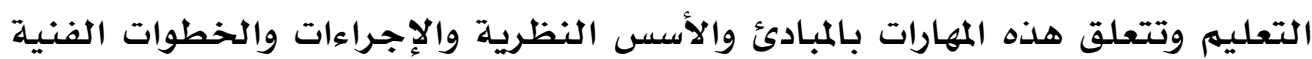

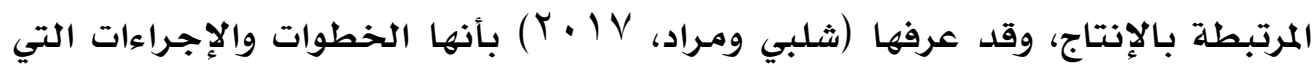

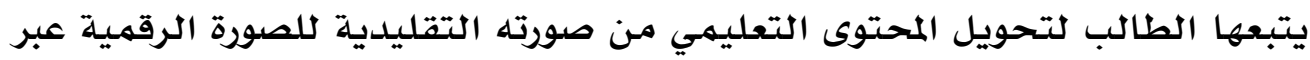

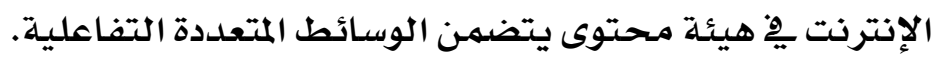

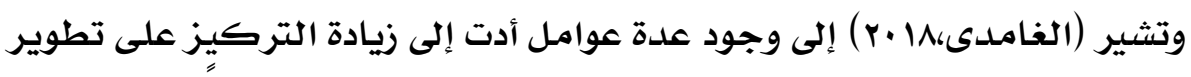

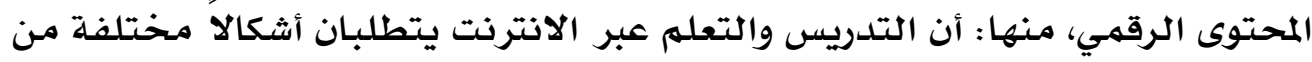

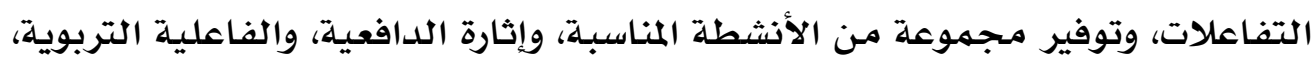

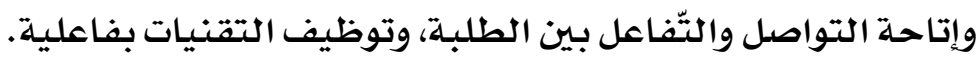

ويمكن القول أن مهارات إنتاج المحتوى الرقهي هي المهارات التي ينبغي أن منادئي

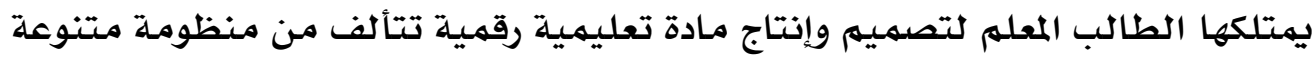

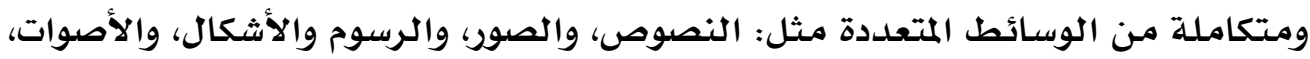

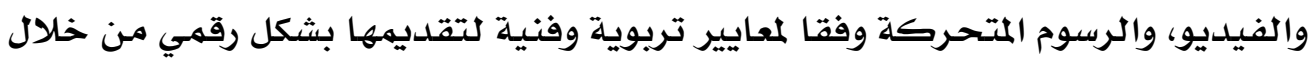
أجهزة الحاسب أو شبكة الإنترنت بغرض وفيكا لمقير تربوية الأهداف التعليمية.

وٌِِ إطار متصل فقد تناولت بعض الدراسات والبحوث السابقة تنمية مهارات

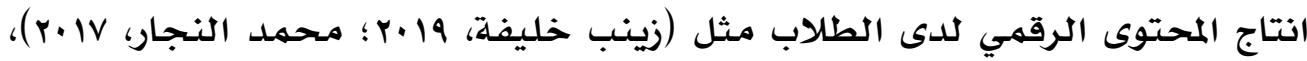

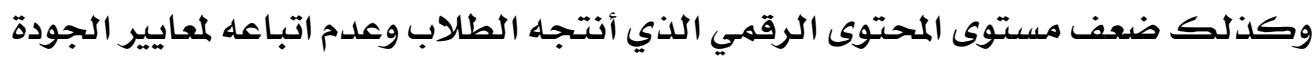

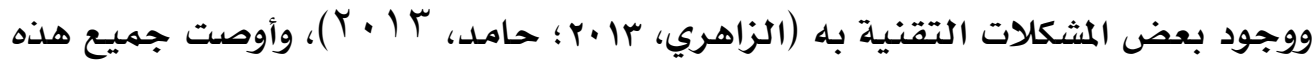

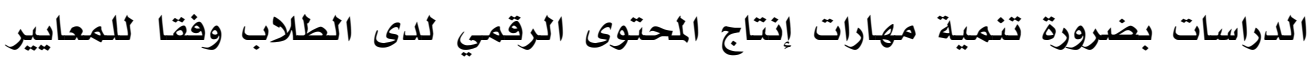

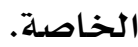

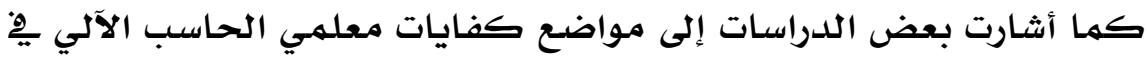

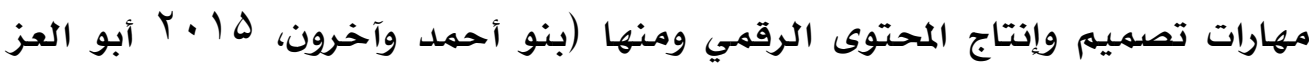

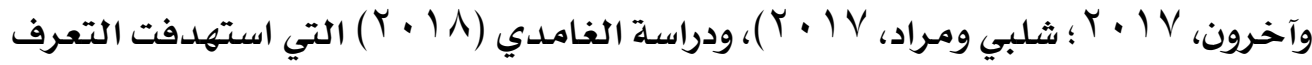

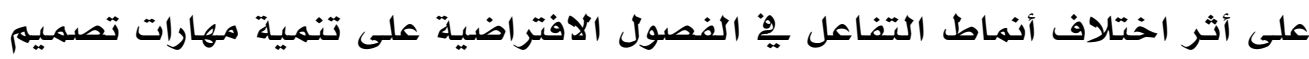


المحتوى الرقهي لدى عينة مكونة من ( (0) معلمة حاسب آلي، وأظهرت النتائج وجود

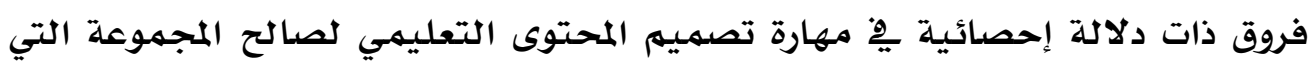
درست باستخدام نهط الفصل الافتر اضي غير المتزامن.

\section{تصميم المحتوى الرقمي}

يتكون المحتوى الرقهي من مجموعة من العناصر المتداخلة مـع بعضها تتمثل

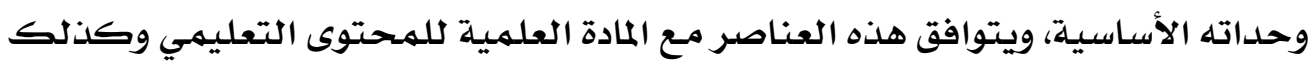
مـع خصائص الطلاب، ومن هذه العناصر النص المكتوب المسموع، والتصوير الثابتة

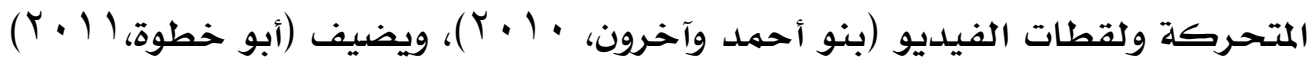

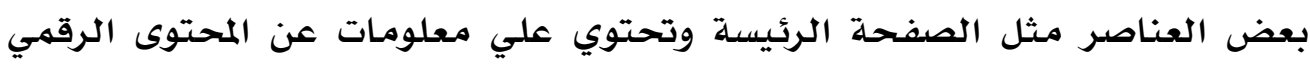

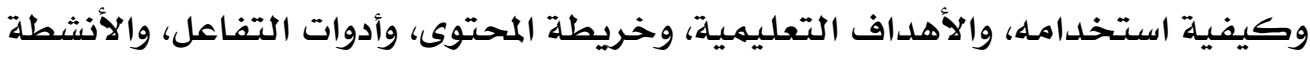

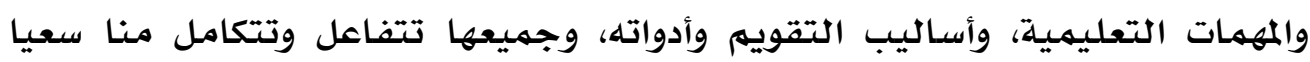
لتحقيق الأهداف التعليمية المنشودة والميهات

وينتج عن التصميهم والإنتاج الجيد للهحتوى الرقهي تعلم فعال ومتهيز، مها

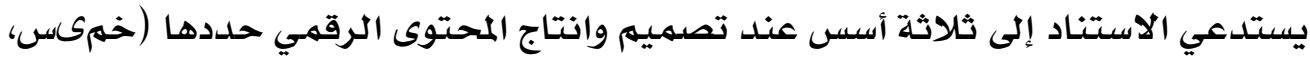

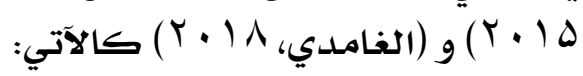

الأسـاس النظري (النظريات) Theoretical : تعد نظريات عله النفس التعليهي أحد أهم الأسس التي لا يهكن إغفالها أثناء تصميهم وإنتاج المحتوى الرقيمي فوفقا لطبيعـة العمليات العقلية والإدراكية للطالب تتحلدد النظريـة التي يستند إليها المحتوى.

الأسساس التربوي: يتعلق بخصائص وحاجات الطلاب وأسلوب تعلمهمه ودافعيتهم.

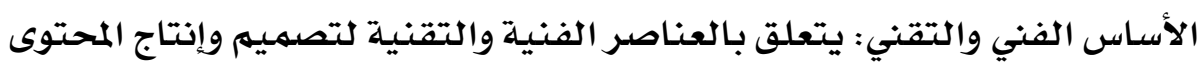

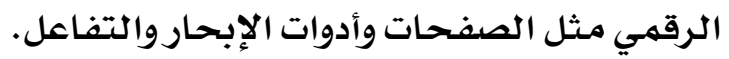

وِِّ ذات الإطار فإن من العوامل الرئيسة لزيادة فاعلية المحتوى الرقهي وتحقيقه لأهدافه هو مدي

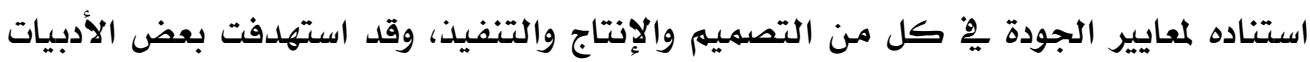

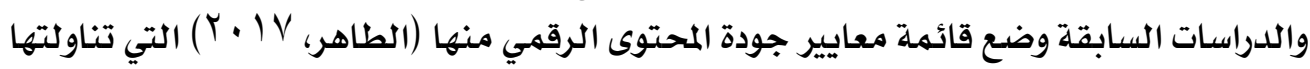

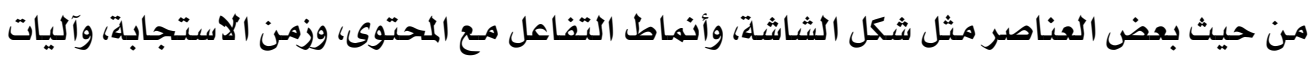

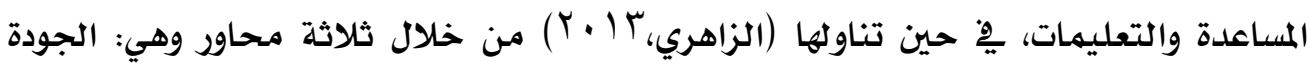

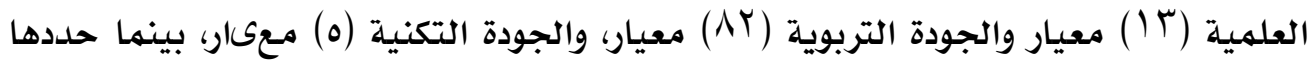

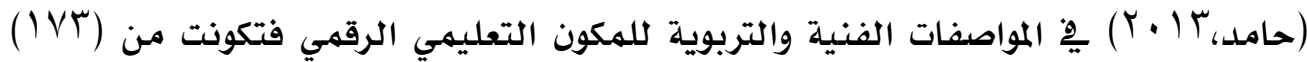


مواصفة فنية تغطي عدة عناصر مثل المحتوى والألوان والروابط والابحار والتفاعل، و (91)

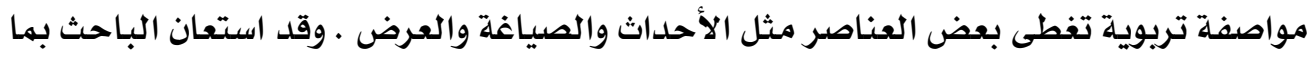

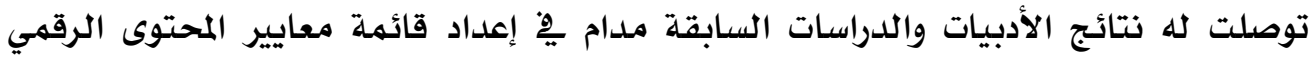
ومؤشراتها.

\section{إجراءات البهث}

أولاً_بناء قائمة بمهارات إنتاج المحتوى الرقمي:

تم إعداد قائمة مهارات إنتاج المحتوى وفق الخطوات التالية:

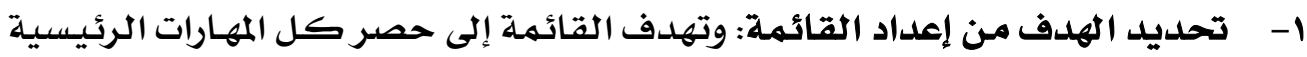

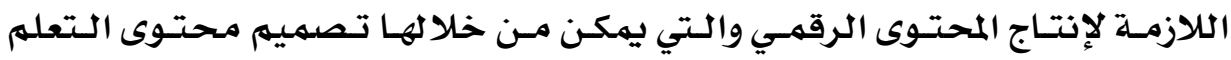

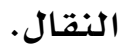

r- تحديد مهارات إنتاج محتوى التعلم النقال وذلك من خلال:

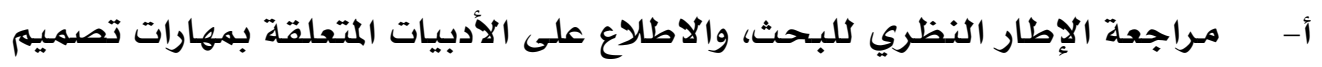

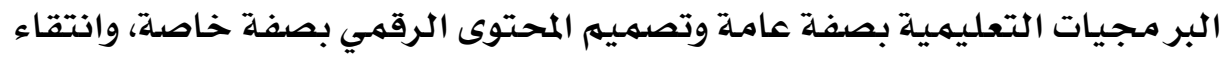

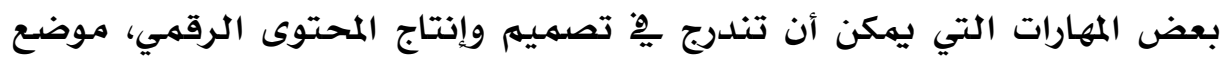

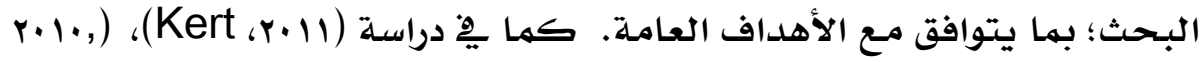
Basoglu \& Akdemer

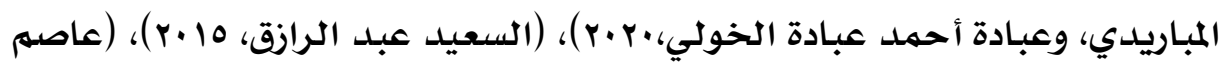

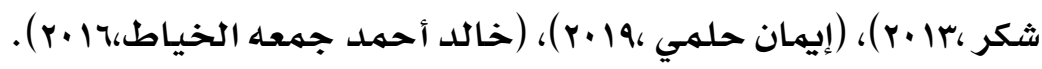

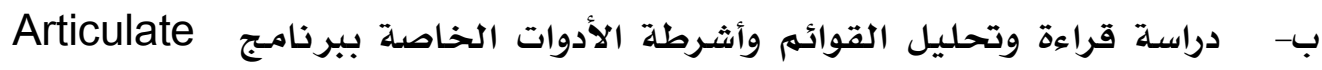
Storyline بعض الشروحات للبرنامج الخاصة بذلك.

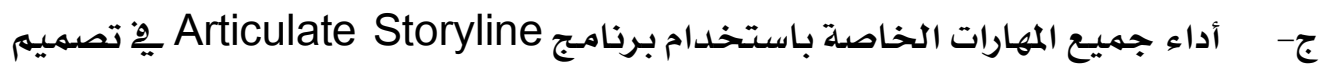

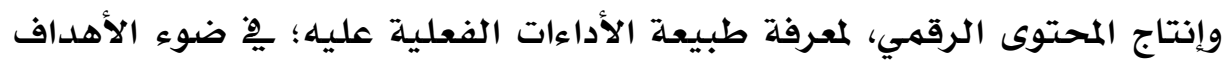
العامـة للبرنامج.

د- دراسة قراءة وتحليل الوظائف الخاصة بتطبيق ibuildapp المستخدم مِّ تصميم

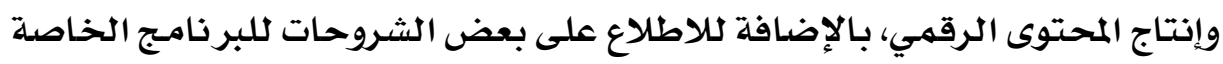


ه- أداء جميع المهارات الخاصة باستخدام بتطبيق ibuildapp في تصميهم وإنتاج

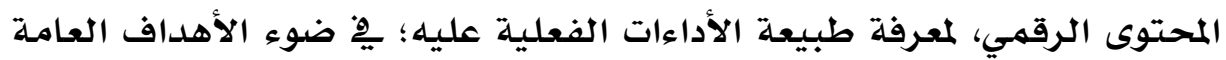

$$
\text { للبرنامـج. }
$$

و- الاستعانة بآراء مصمهي البرامج التعليمية عبر الإنترنت من خبراء، ومداءرسين،

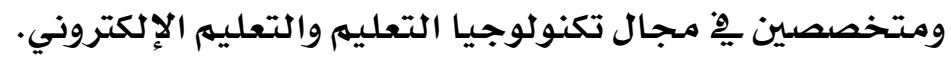

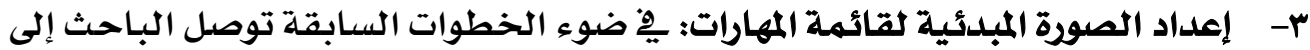

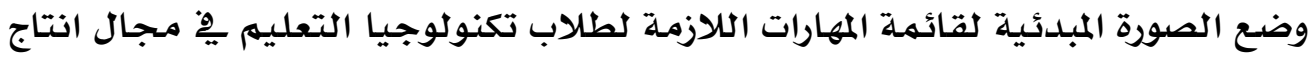

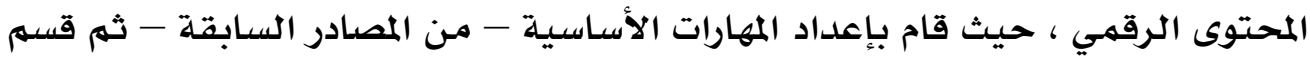

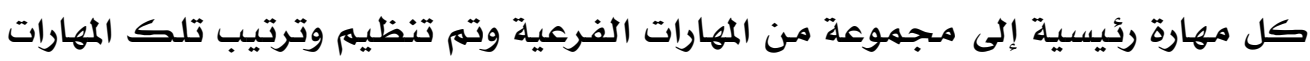

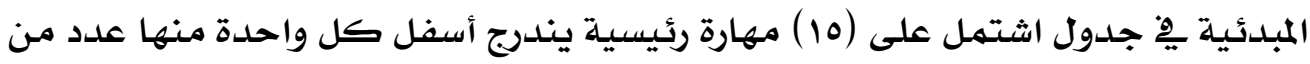

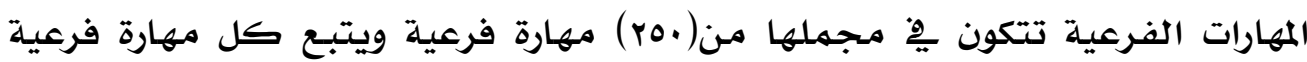
مجموعة من الإجراءات لتنفيذها.

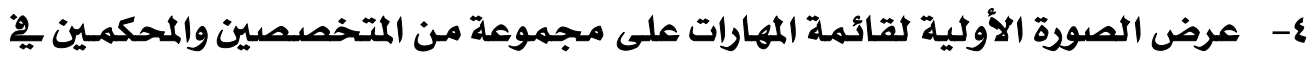

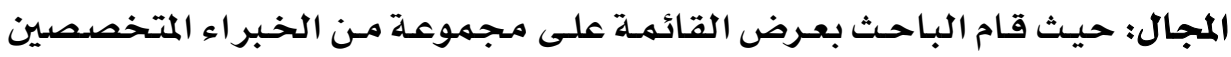

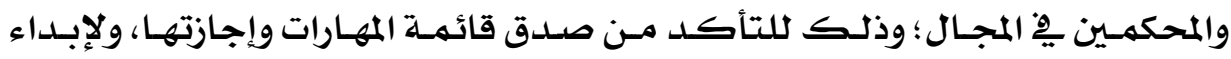
الرأي ِِّ مضمون القائممة.

وقد أبدى الخبراء والمتخصصون آراء مستوفاة حول المهارات التي شملتها القائمهة، وتم

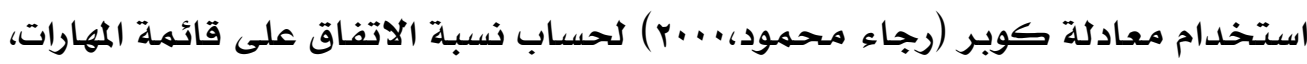

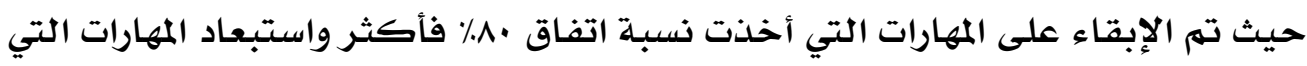

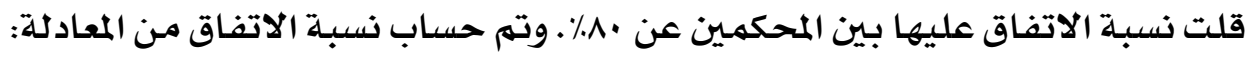

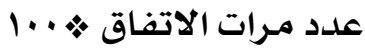

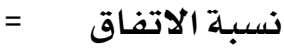

عدد مرات الاتفاق + عدد مرات الاختلاف

كما رأى بعض السادة المحكمين ضرورة إجراء بعض التعديلات على القائمة المبدئية

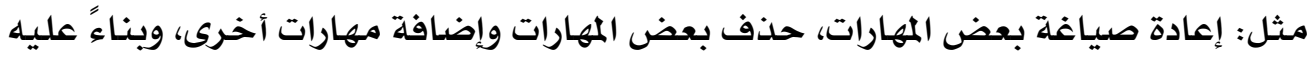

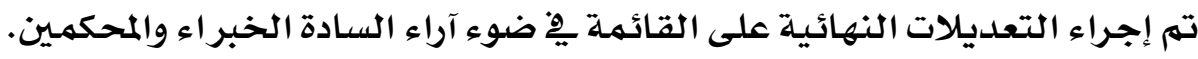


0- إعداد الصورة النهائية لقائمة المهارات:

ويْ ضوء آراء السـادة المحكمهين تهم إجراء التعديلات التي اقترحها السـادة المحكمون على

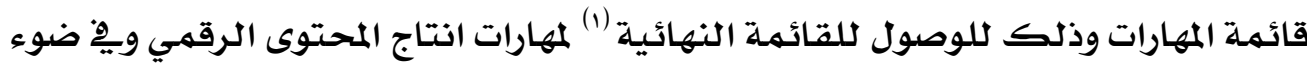

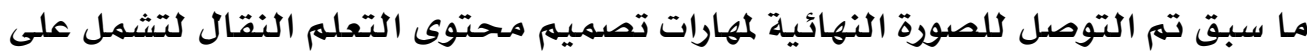

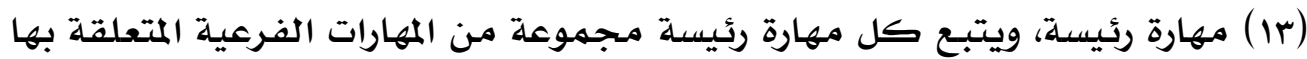

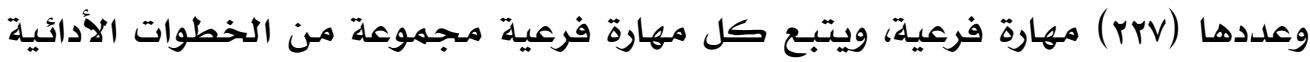

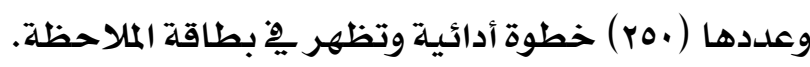

ثانياً - اشتقاق قائمة معاير تصميم بيئة التعلم النقال القائم على عناصر التعلم الرقمية. تحديد الهدف من إعداد القائمسة: وتهدف هذه القائمسة إلى عمل حصر للهعايير التي يجب توافرها لتصميهم بيئة التعلهم النقال التعليمية لدى طلاب تكنولوجيا التعليه. إعداد الصورة المبدئية لقائمة المعايير : قام الباحث من خلالال الاطلاع على الدراسـات

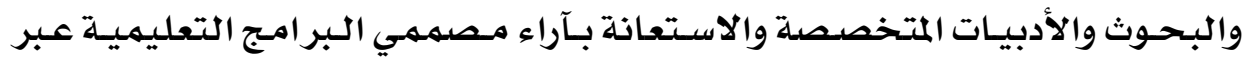

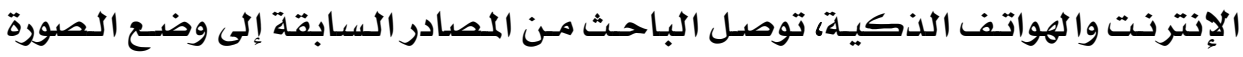

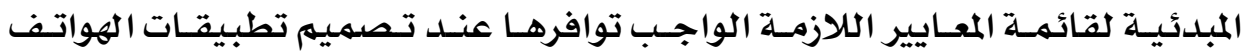

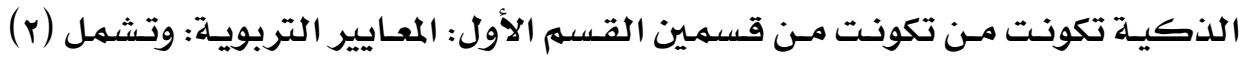

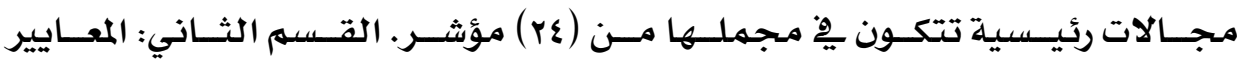

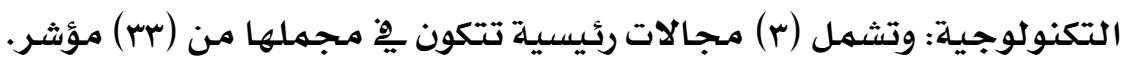

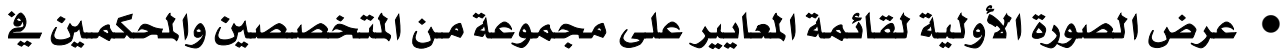

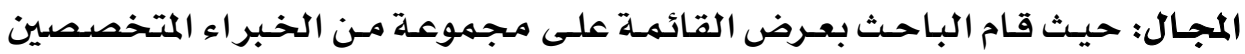

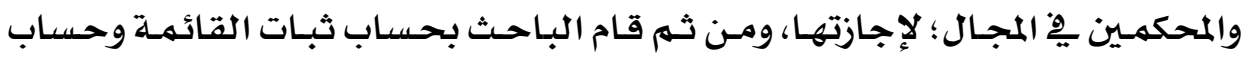

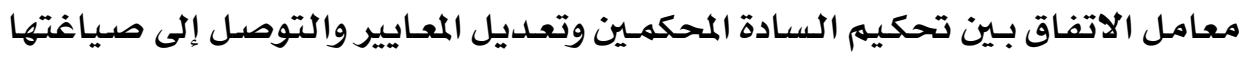

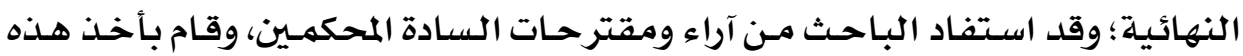

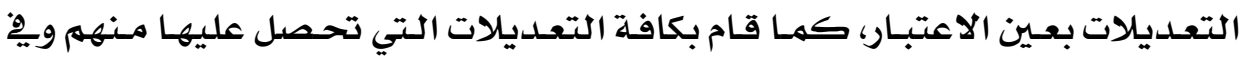

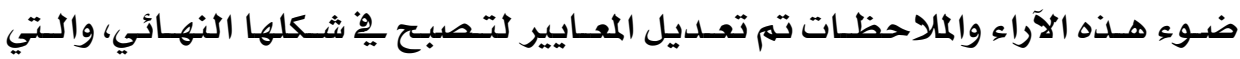

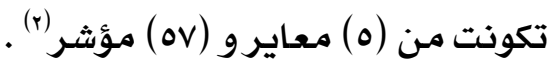

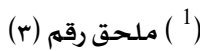
( ) ( 


\section{ثاثلًا: تصميه بيئة التعلم النقال القائم على وحدات التعلم الرقمية.}

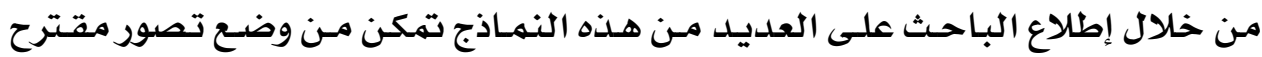

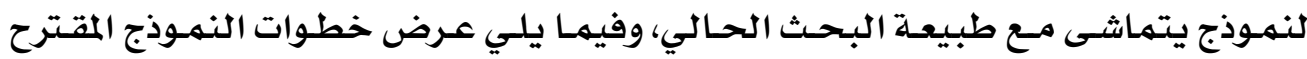
وكيفية إجراء كل خطوة منها:

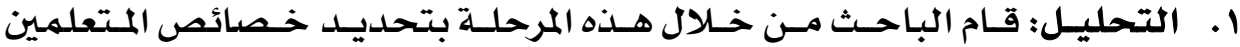
وتحديد الحاجات التعليمية للتطبيق وكذلك الكيات الحاجات المعيارية ودراسة البيئة

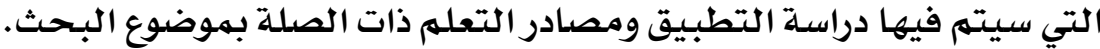

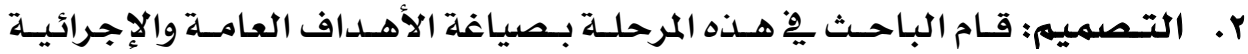

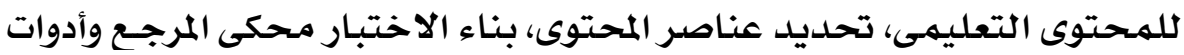

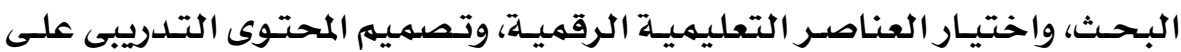

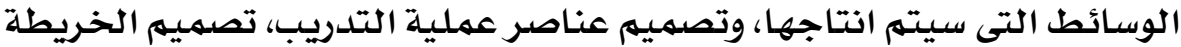
الانسيابية وواجهة التفاعل مـع البرنامجه، ووضع استراتيجية التدريب. r. الإنتاج: تم يِّ هذه المرحلة إنتاج وتجميع الوسائط المتعددة للمحتوى التعليمى،

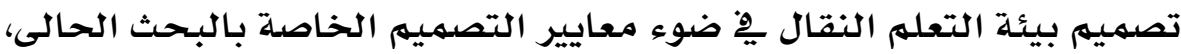

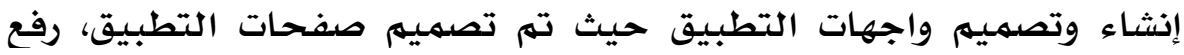
المحتوى التعليهي على التطبيق وتحرير الاختبارات.

ع. مرحلة التقويم البنائى للبرنامـج: يِّ هذه المرحلة تم عرض بيئة التعلم النقال

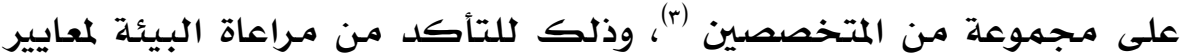

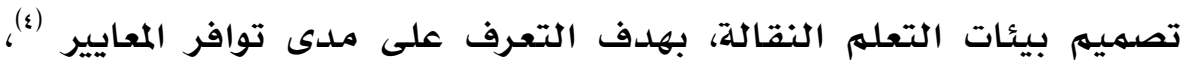

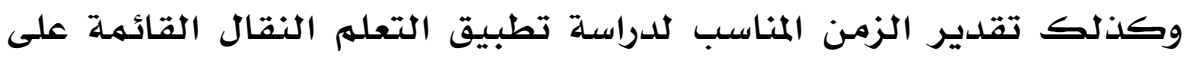
عناصر التعلم الرقهية. تصميي أدوات القياس

قام الباحث بإعداد أدوات القياس، للتأكد من تحقيق الأهداف المحددة، والتي يتم تطبيقها قبل وبعد التدريب لتنمية مهارات تصميه وإنتاج المحتوى الرقهي، حتى التهن

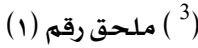

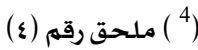


يستطيع الباحث الحكم على مـا إذا كان طلاب الدراسـات العليا قد وصلوا الى مستوى

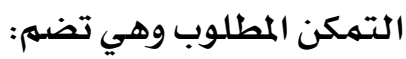

\section{أولاً: الاختبار التحصيلي لقياس الجوانب المعرفية تتنمية مهارات اتتاج المحتوى الرقمي:}

تم تحديد المواصفات الأولية كلاختبار، وصياغة الأهداف الإجرائية، وتحليلها

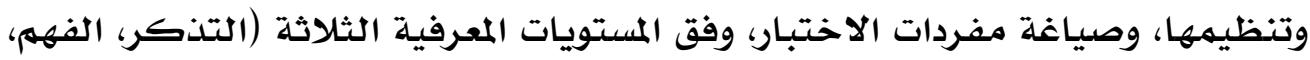

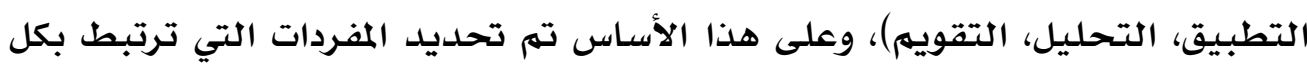

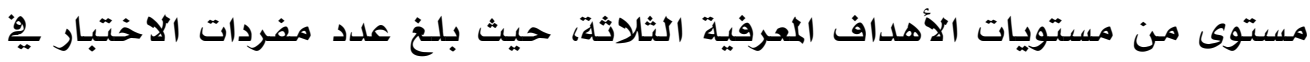

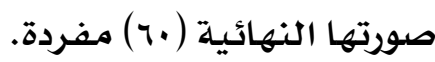

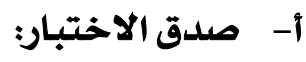

تم ضبط الاختبار من خلال التحقق من صدقه حيث تم عرض الاختبار على

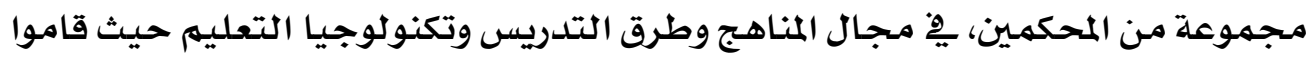

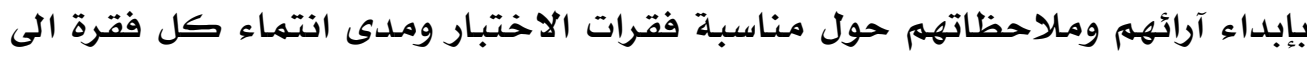
البعد الذي تنتهمي إليه.

$$
\text { ب- ق قياس معامل الاتساق الداخلي: }
$$

قام الباحث بالتأكد من ثبات الاختبار التحصيلي بواسطة قياس معامل

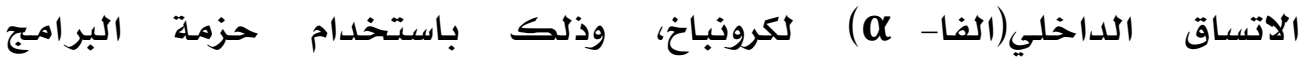

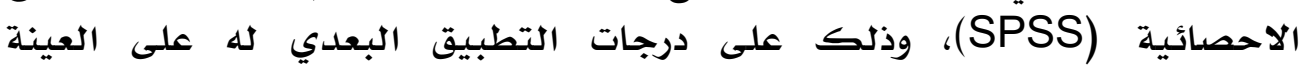

\begin{tabular}{|c|c|c|c|}
\hline القيمة & مفردات الاختبـار & عدد العينة & معامل الثبات \\
\hline$\cdot, V_{1}$ & 7. & 0 & معامل ألفا \\
\hline
\end{tabular}

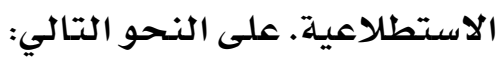

شكل 1 ذتائج حسـاب معامل الثبات (A) للاختبـار التحصسيلي البعدي

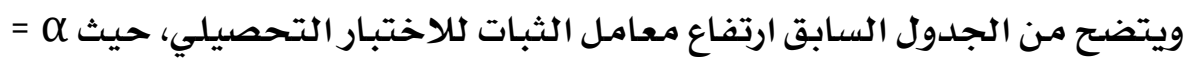
VI, •، وذلك يدل على دقة الاختبار مِ القياس واتساقه.

ثثانياً: بطاقة ملاحظة أداء لقياس الجوانب الأدائية لتنمية مهارات اتثاج المحتوى الرقمي: هدفت بطاقة الملاحظة إلى قياس مستوى أداء طلاب الدراسات العليا لتنهية مهارات انتاج المحتوى الرقهي، قبل وبعد دراسـة مادة المعالجة التجريبية. 


$$
\text { 1 - التحقق من صدق البطاقة: }
$$

وللتحقق من صدق البطاقة، تم عرضها على مجموعة من المحكمين والخبراء،

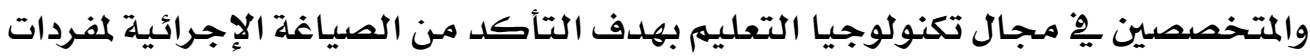

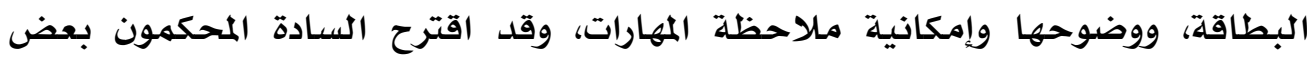

$$
\text { التعديلات المهمة. }
$$

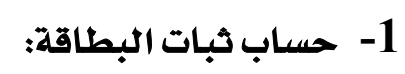

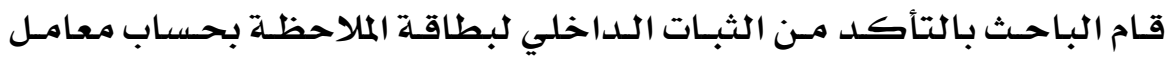

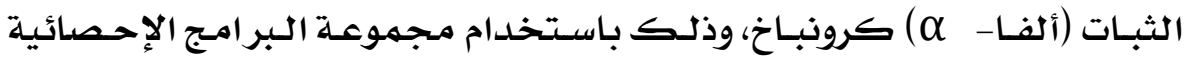
الـ(SPSS)، ويوضح الجدول (1) (1) نتائج قياس الثبات الإحصائي.

\begin{tabular}{|c|c|c|c|}
\hline القيمـة & مفردات بطاقة الملاحظة & عدد العينـة & معامل الثبـات \\
\hline - V9A & ro. & 0 & معامل"ألفا"Cronbach \\
\hline
\end{tabular}

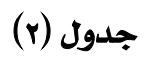

نتائج حساب معامل الثبات(م) لبطاقة الملاحظة

ويتضح من الجدول (2) ارتفاع معامل ثبات بطاقة الملاحظة (798.0) مما يدل

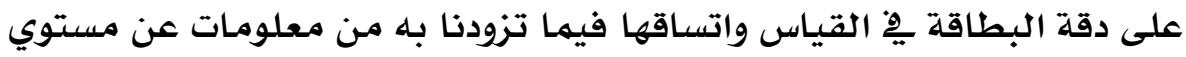
أداء أفراد عينة.

\section{إجراءات تطبيق بيئة التعلم النقال القائم على وحدات التعلم الرقمية}

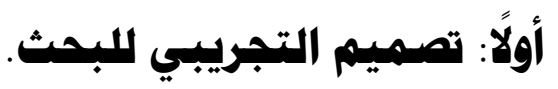

تم استخدام التصميم التجريبي المعروف باسم التصميم القبلي البعدي

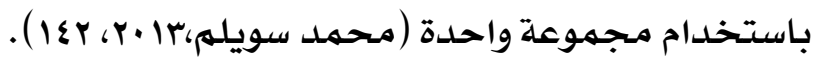

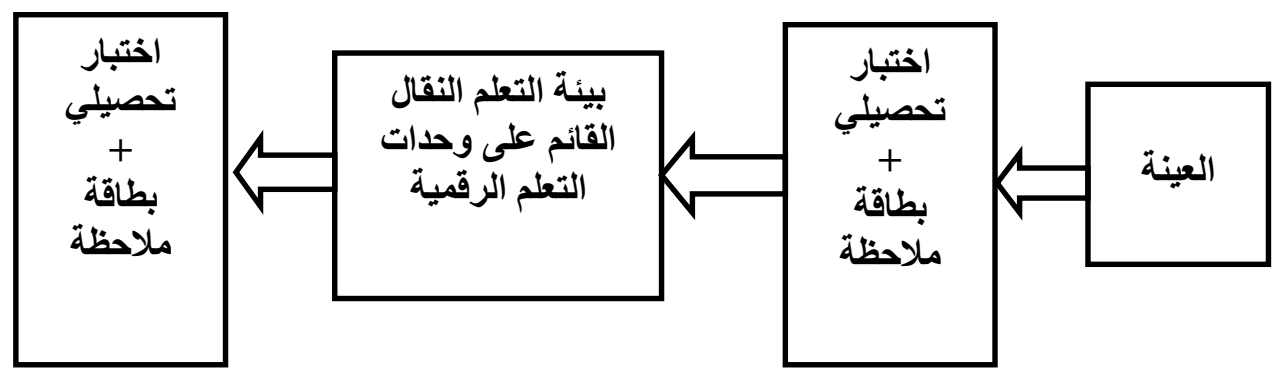




\section{تجربة البحث:}

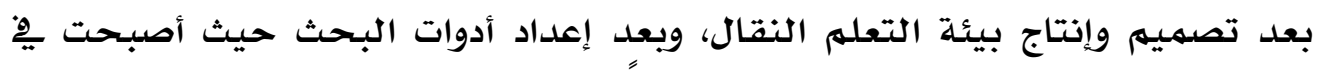

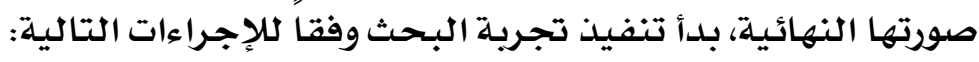
ا - - تطبيق أدوات البحث قبلياً. r - تنفيذ التجربة الأساسية. r- ت تطبيق أدوات البحث بعدياً.

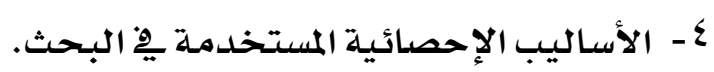

ثانيًا: اختيار هجموعة البحث تم اختيار عينة البحث من طلاب الدراسات العليا وبلـخ عددهم (rr ) متدرب.

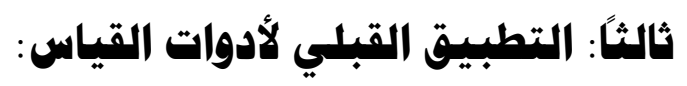

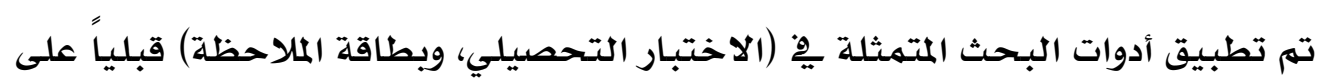

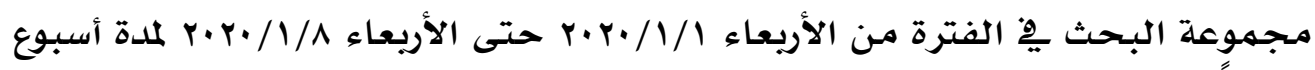
تقريباً.

\section{رابهًا: تطبيتق بيئة التعلم النقال:}

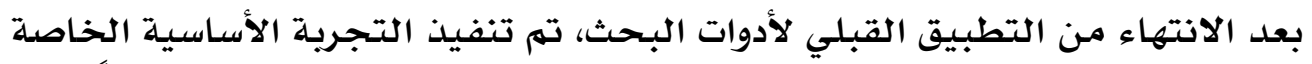

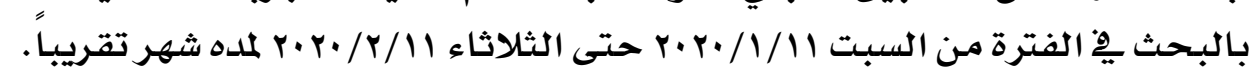
خامساً: التطبيتق البعدي لأدوات القيساس:

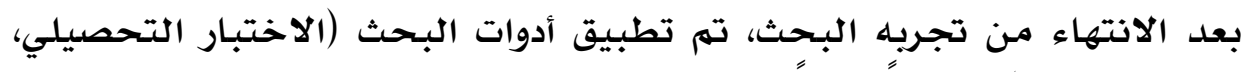

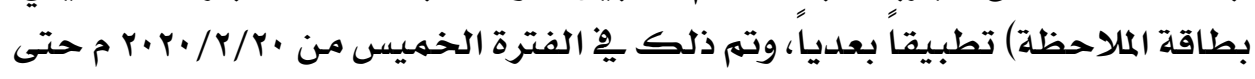

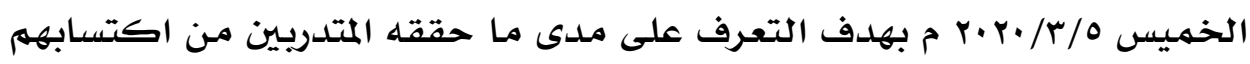

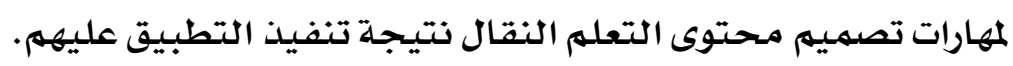


سادساً: الأساليب الإهصائية المستخدهة لمعالجة بيانـات التطبيسق القبلي والبعدي لأدوات القيساس.

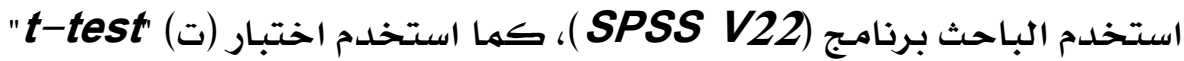

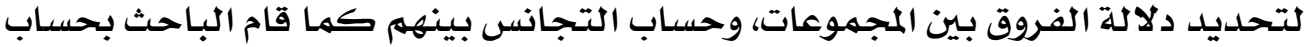

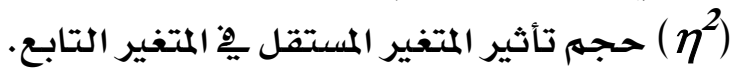

\section{نتائج البحث وتفسيرها:}

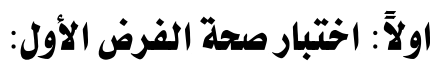

ينص هـذا الفـرض على أنـه: " يوجـد فرق دال إحصائياً عندـ مستوى (ه ...) بـين

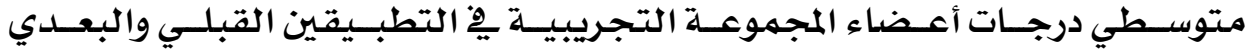

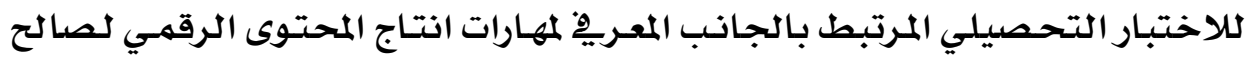

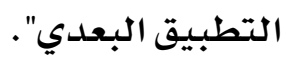

ولاختبار صحة هـذا الفرض قام الباحث بتطبيق اختبـار "ت" (t-test) للعينـات

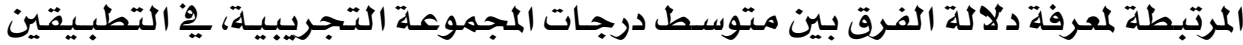

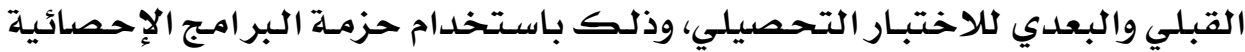
.SPSS"

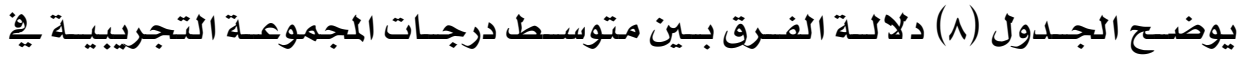
التطبيقين القبلي والبعدي للاختبار التحصيلي:

جدول )1(اختبار"ت" للعينات المرتبطة، ودلالتها الإحصائية للفرق بين متوسط درجات

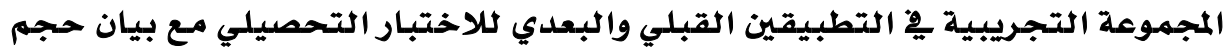
التأثير

\begin{tabular}{|c|c|c|c|c|c|c|c|c|}
\hline حجم التأثير & مستولة الدلاية & الدرجية & الميلهوبة & الانحراف المعياري & التوسط & j & التطبيق & مستويات \\
\hline$\% 91$ & \multirow{2}{*}{ دالة عند } & \multirow{2}{*}{22} & \multirow{2}{*}{36.5} & 3.21803 & 12.9 & \multirow{2}{*}{ rr } & القبلي & \multirow{2}{*}{ للدرجة الكلية } \\
\hline كبير & & & & 5.12839 & 52.9 & & البعدي & \\
\hline
\end{tabular}

ويتضح من نتائج الجـدول (^) ارتفاع متوسط درجـات أفراد المجموعة التجريبيـة 


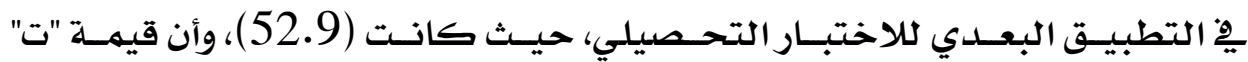

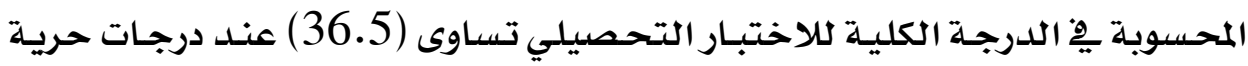

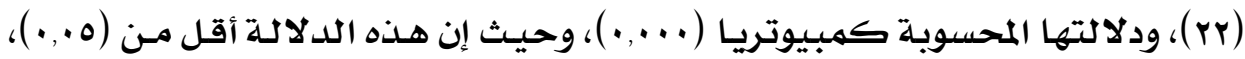

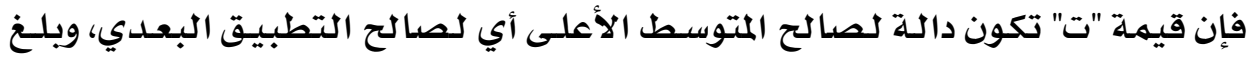

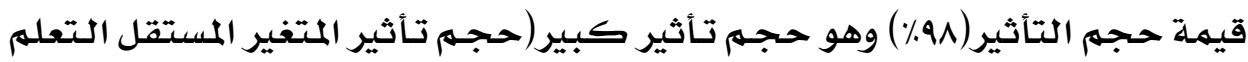

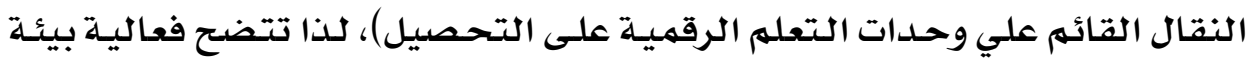

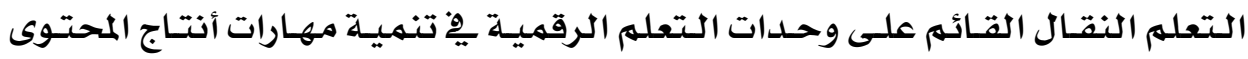

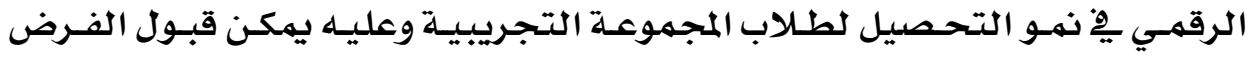

$$
\text { البحثثي الأول. }
$$

\section{ثانياً: اختبار صحة الفرض الثاني}

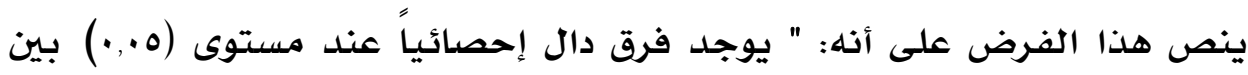

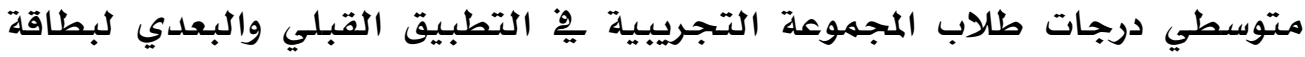
ملاحظة مهارات إنتاج المحتوى الرقهي لصالح التطبيق البعدي".

ولاختبار صحة هذا الفرض قام الباحث بتطبيق اختبار "ت" (t-test) للعينات

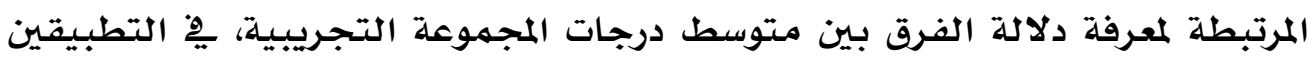

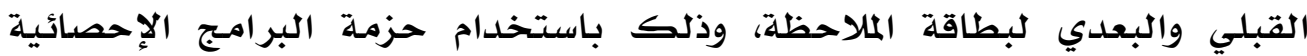
"SPSS"

جدول( 2)اختبار"ت" للعينات المرتبطة، ودلالتها الإحصائية للفرق بين متوسط درجات المجموعة التجريبية ِِ التطبيقين القبلي والبعدي لبطاقة الملاحظة مـع بيان حجم التأثير.

\begin{tabular}{|c|c|c|c|c|c|c|c|c|}
\hline حجم التأثير & مستولة الدلالة & العرجية & قالمسوبة & الانحراف المعياري & المتوسط & ن & التطبيق & الههارات \\
\hline 多 94 & دالة عند & \multirow{2}{*}{22} & \multirow{2}{*}{16.4} & 29.41 & $r \$ 0, Y$ & \multirow{2}{*}{ rr } & القبلي & \multirow{2}{*}{ للدرجة الكلية } \\
\hline كبير & •, & & & 55.7 & orq, $A$ & & البعدي & \\
\hline
\end{tabular}

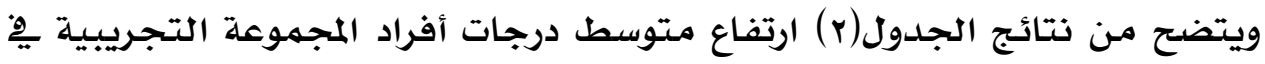

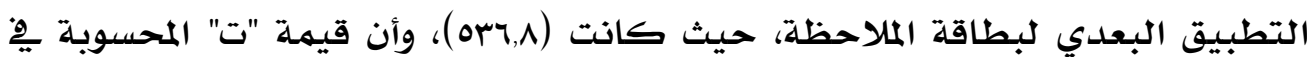

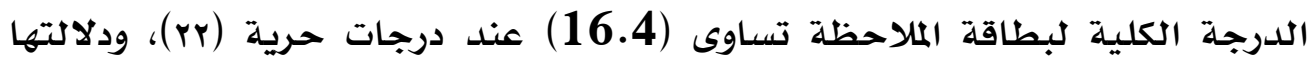

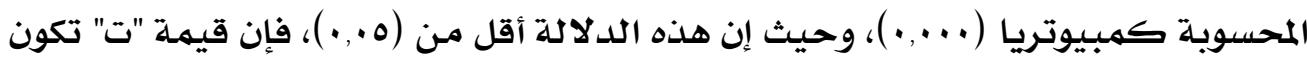


دالة لصالح المتوسط الأعلى أي لصالح التطبيق البعدي، لذا تتضح فعالية تصهيه

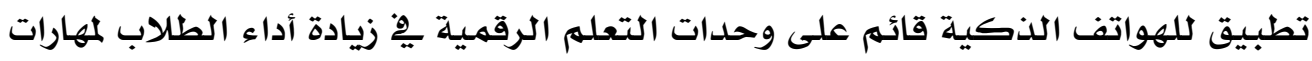
إنتاج المحتوى الرقهمي، وعليه يهكن قبول الفرض البـحثي الثاني. وتتفق الدراسـة الحالية مـع العديد من الدراسـات التى توصلت إلى أن بيئة التعلهم النقال

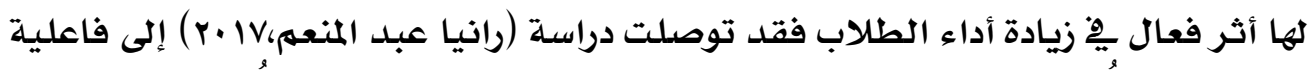
توظيف التعلهم النقال عبر الهواتف الذكية يخ تنمية مهارات التعلهم الذاتى ومهارة

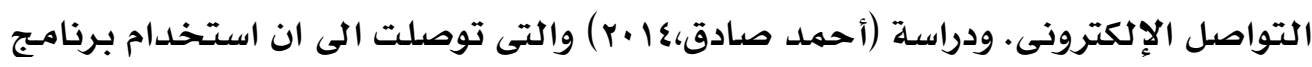

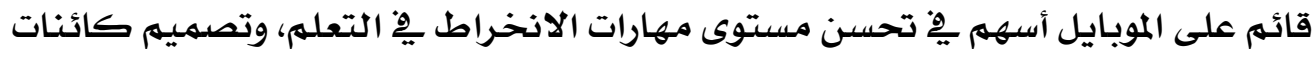

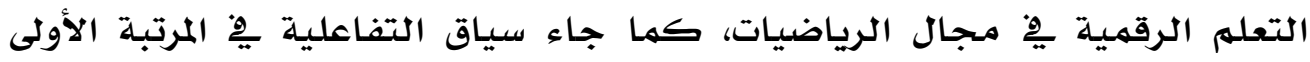
للسياقات التي لها تأثير كبير على تعلهم الرياضيات عبر الموبايل. ثالثًا: اختبار صحة الثرض الثالث ينص هذا الفرض على أنه: يوجد فرق دال إحصائياً عند مستوى دلادة (ه., ) بين

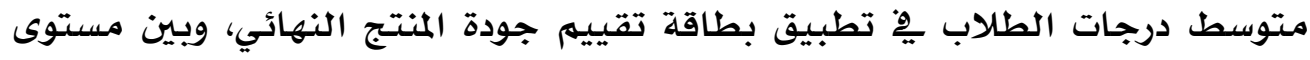

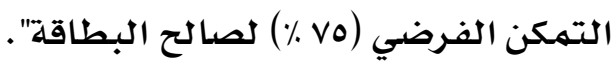

ولاختبار صححة هذا الفرض قامت الباحثة باستخدام اختبار (t) لدلالة الفرق بين

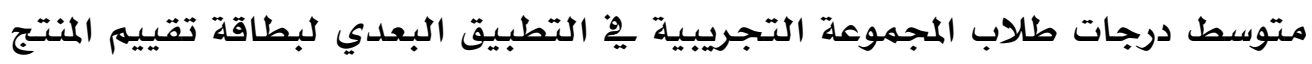

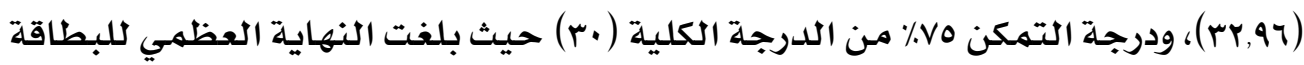

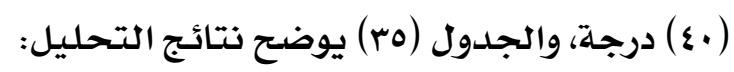

جدول 3دلالة الفرق بين متوسط درجات طلاب المجموعة التجريبية يِ التطبيق البعدي

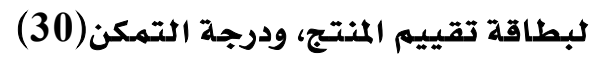

\begin{tabular}{|c|c|c|c|c|c|}
\hline مستوي الدلالة & الدرجة & قيمة (ت) المحسوبة & المترق بين & المتوسط & نوع التطبيق \\
\hline دالة عند مستوي & rr & $\boldsymbol{r}, \boldsymbol{\xi}$ & r,97 & $\begin{array}{l}\text { rr, } 97 \\
\text { ro }\end{array}$ & مستوى التمكن الفرضي تقتيم المتتج \\
\hline
\end{tabular}

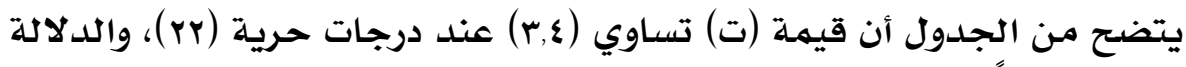

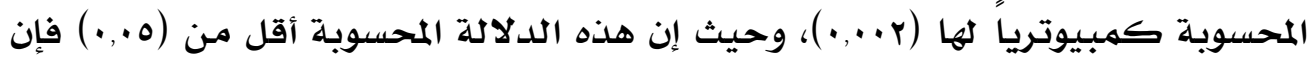

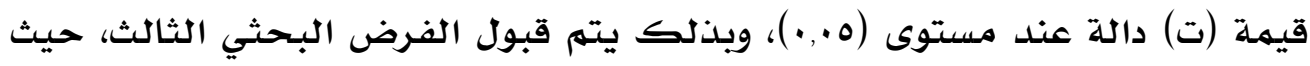


يوجد فرق دال إحصائياً عند مستوى دلاكة (0., •) بين متوسط درجات طلاب المجموعة

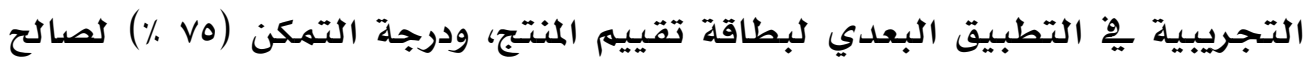

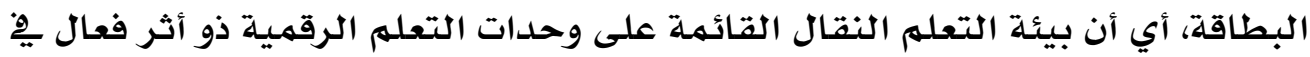

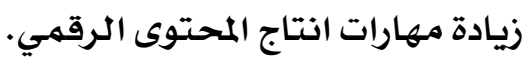
تفنسير تثائج البحث ومناقشتثها

يتضـح من النتائج السـابقة أن تصميهم تطبيق قائمر على وحدات التعلهم الرقمية أثر بشكل

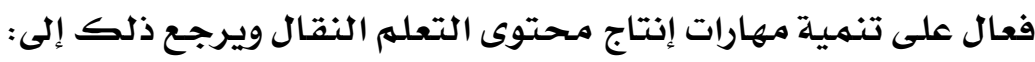

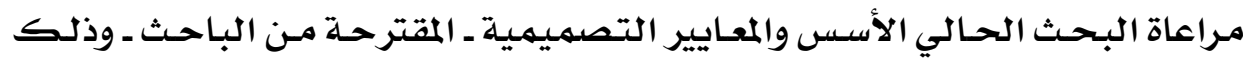

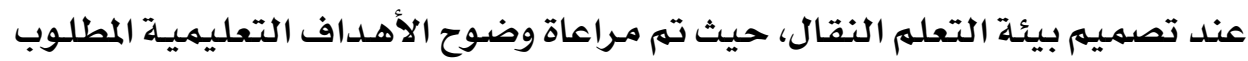

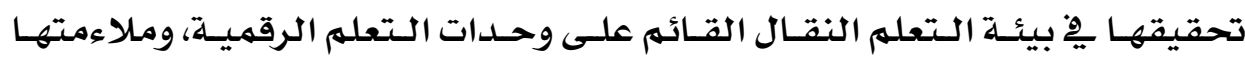

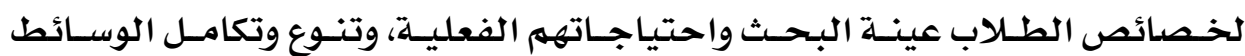
التعليهية، وتحكم المتعلمون فِ تعلهمهم.

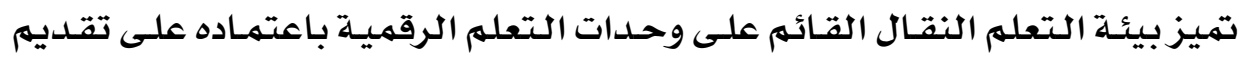

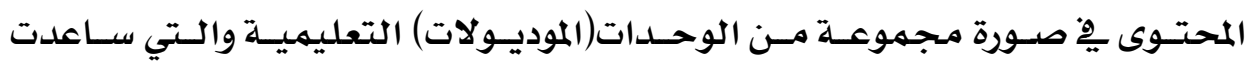

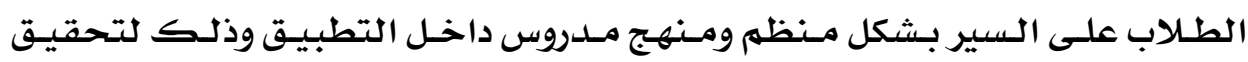

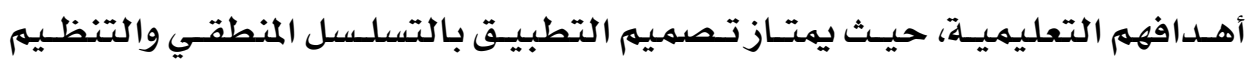

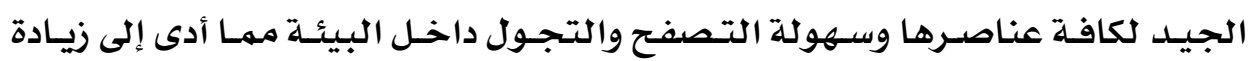

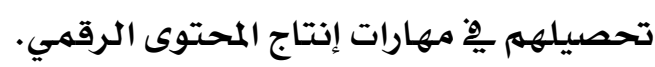

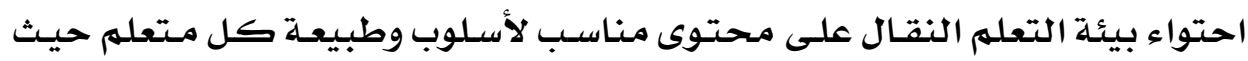

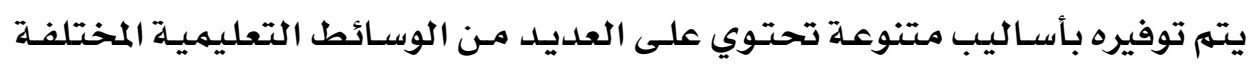

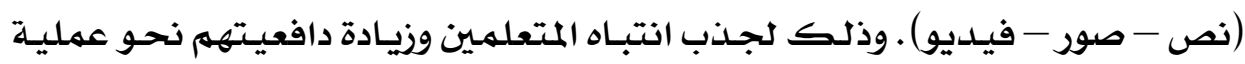
التعلم. احتواء بيئة التعلهم النقال على أدوات الاتصـال المتزرامن والغير متزرامن مهـ كـان لـه

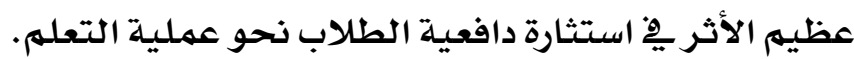

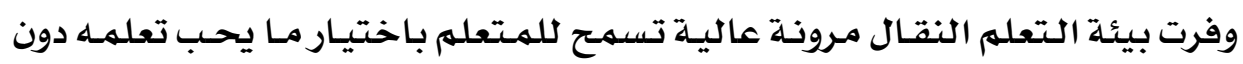

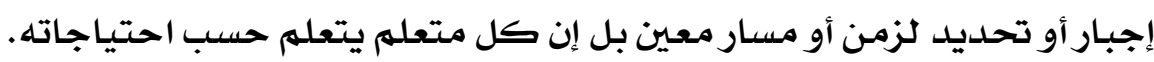

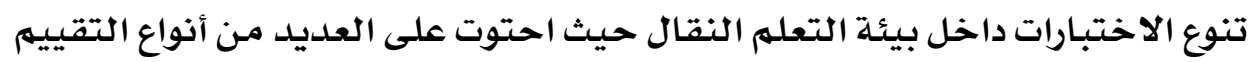

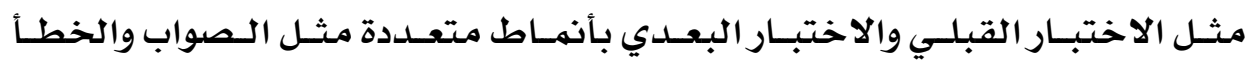


والاختيار من متعدد وذلك لمسـاعدة الطالب على تحديـ مستواه التعليهـي وارتفـاع

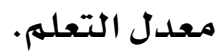

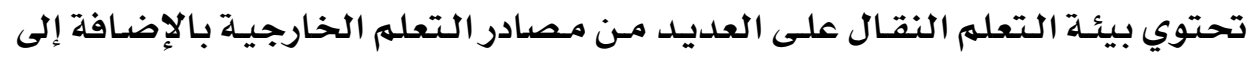

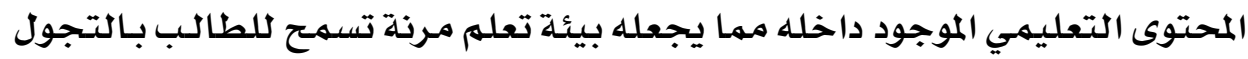
داخلها وخارجها.

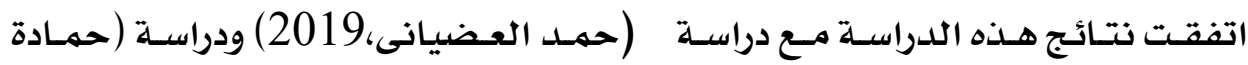

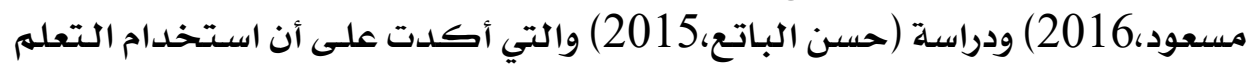

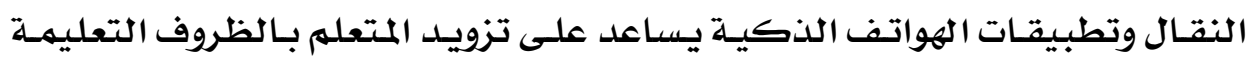

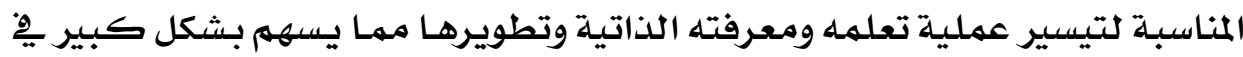
زيادة دافعيته واستثارة حماسـه تجاه عملية التعلهم.

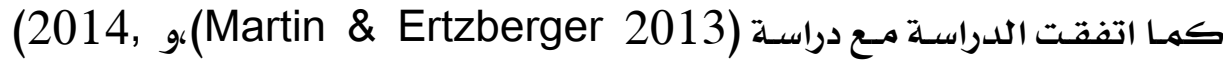

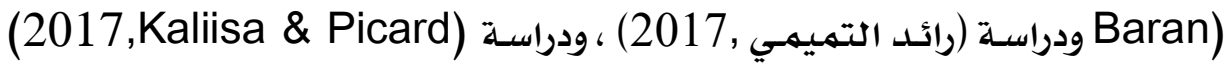

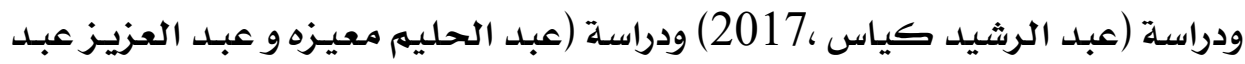

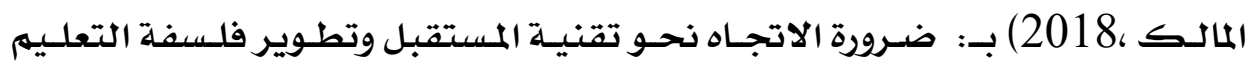

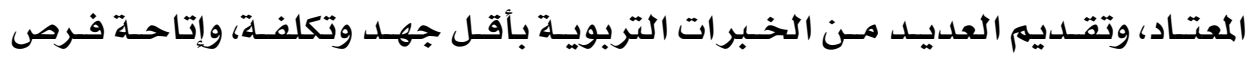

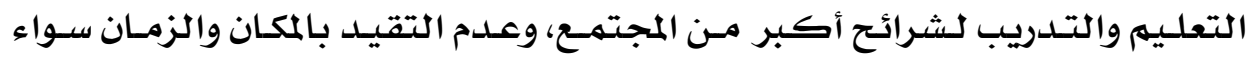

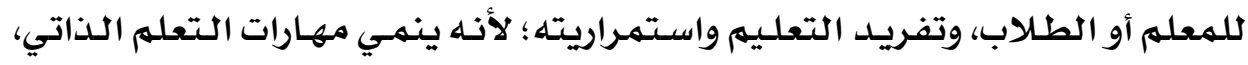

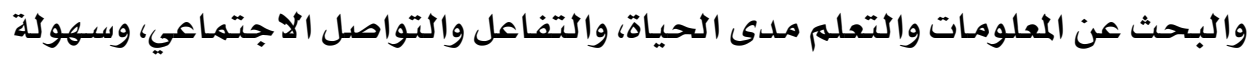

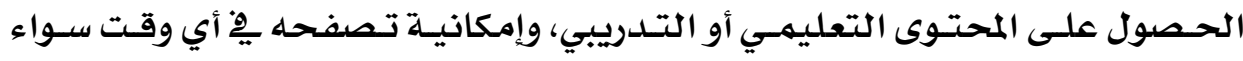
بالاتصال بالإنترنت أو عدم الاتصول المال.

\section{التوصيات والبحوث الإقترحة}

\section{أولاً: توصيات البحث:}

فِ ضوء ضتائج البحث الحالي تبين أن بيئة التعلهم النقال القائمـة على وحدات التعلهم

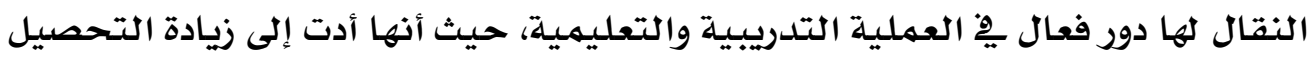
وتنهية المهارات، وتطبيقها، وقد سـاعد استخدام نموذج تصهيه خاص بالبحث إلى إلى زيادة أثر وفعالية التطبيق التدريبي، وعلى ذلك فإن البحث الحالي قد توصل للتوصيات التالية يِّ ضوء أهداف البحثث وأهميته : ا - توظيف بيئات التعلم النقال القائم على وحدات التعلهم الرقمية ِِّ مقررات إعداد 
معلهي التخصصدات المختلفة، حيث أثبتت فاعليتها ِِِ تنهيه الجانب المعرِِِ والأدائي

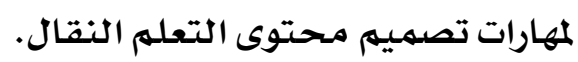
Y- التأكيد على ضرورة الاستفادة من الخدمات التي تقدمها الهواتف الذكية لبيئات

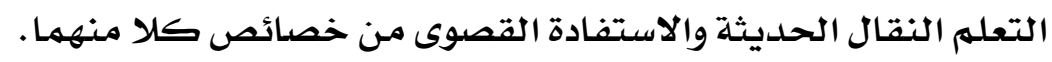
"- عقد برامج تدريبية للهتعلمـين فِ مختلف المراحل الدراسية بكيفية توظيف بيئات التعلهم النقال وفق برامج معده مسبقا يِّ التعليهم والتدريب واعتماد التعلهم النقال كأحد طرق التعلهم الحديثة.

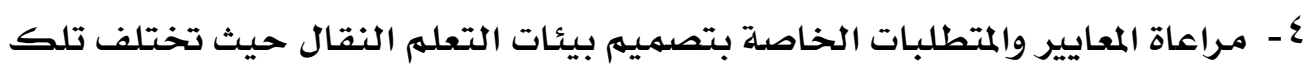

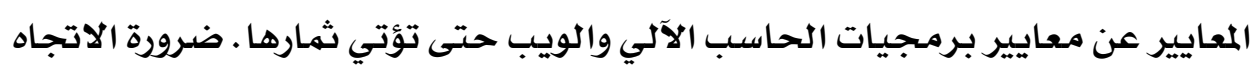

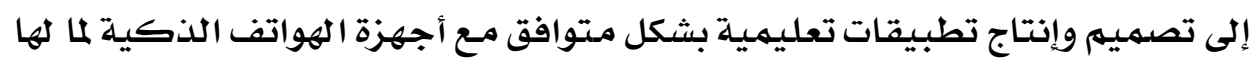
من مهيزات وفوائد عدة.

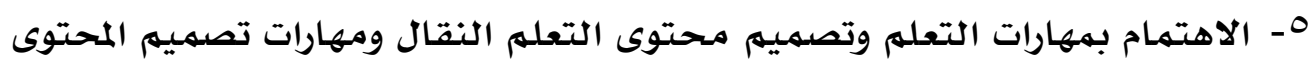
الرقهي الواردة بهذا البحث والعهل على تنهيتها لدى طلاب تخصص الته تكنولوجيا التعليهم.

7- توجيه المبر مـجين العرب إلى إنشاء بيئات تعلهم نقال تعمل بكفاءة وفاعلية مثل التي تقدمها الشركات العالمية تتناسب مـع مجتهمعاتنا وثقافتنا ولغتنتا العربية.

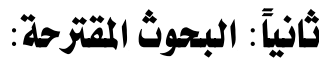

ِِّ ضوء نتائج البحث الحالي، يقترح الباحث بعض الموضوعات ذات الصلة، والتي مـازالت يِّ حاجـة إلى بحوث أخرى ودراسـات أخرى عديدة، وذلك على على النحو التالي:

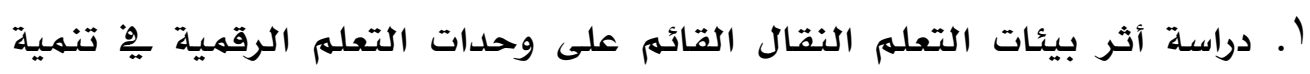

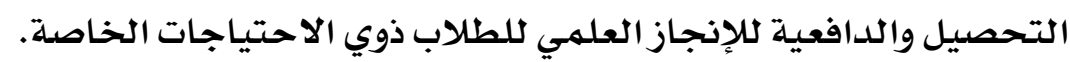
ץ. دراسـة المتطلبات التربوية والتكنولوجية الخاصة ببيئات التعله النقال للبرامجاج

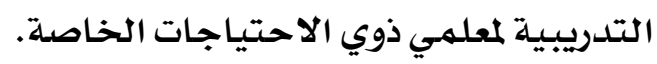

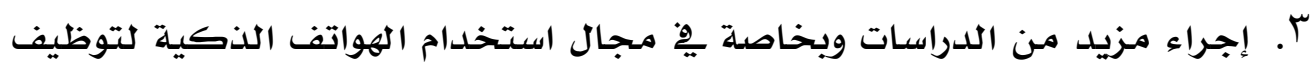

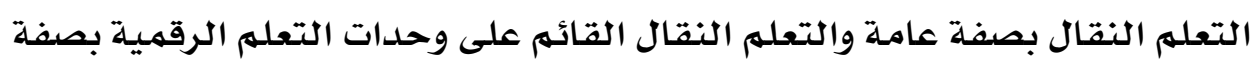

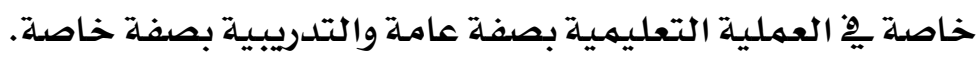


؟. إجراء بحوث تستهدف أثر المتغير المستقل للدراسة الحالية وعلاقته بالأساليب

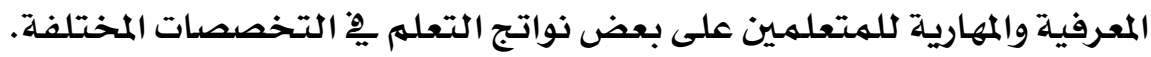

\section{قاعمبة المراجع}

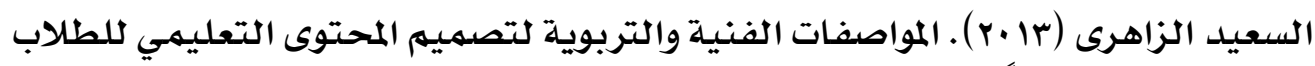

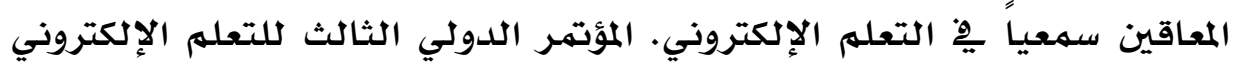

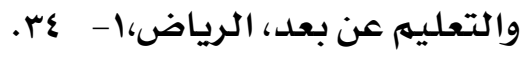

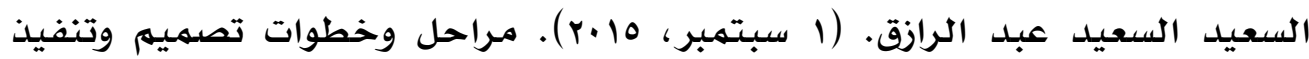

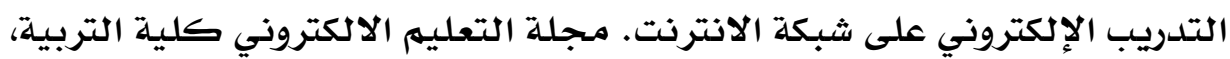
جامعة المنصورة. http://emag.mans.edu.eg/index.php?page=news\&task=show \&id $=224$ السيد عبدالمولى أبو خطوة (11 +r). معايير ضمان الجودة بِّ تصميم المقررات الإلكترونية

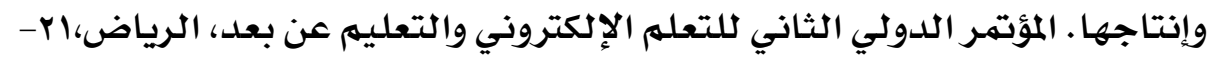

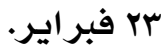

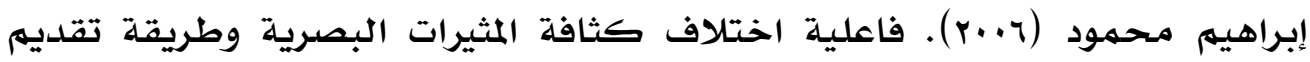

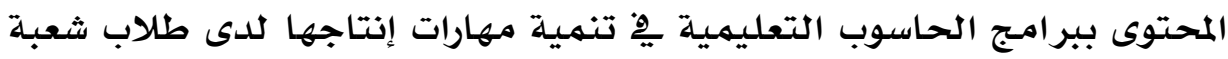

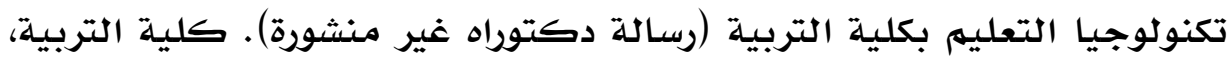
جامعة الأزهر.

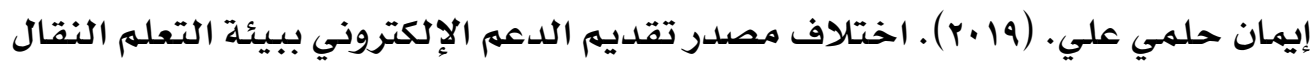

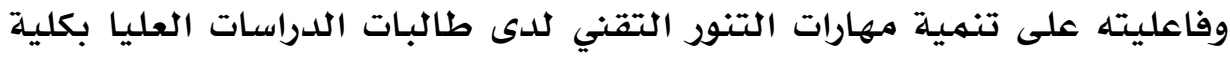

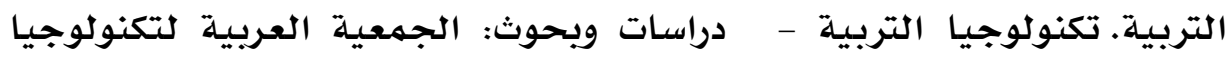

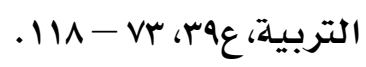

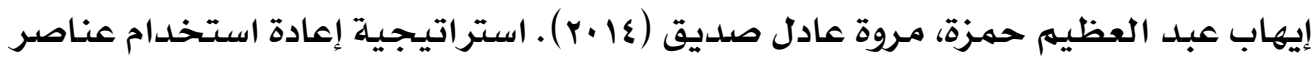

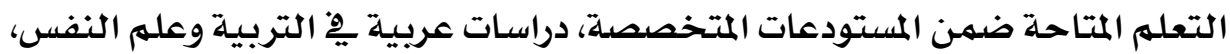

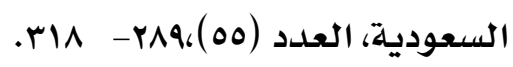

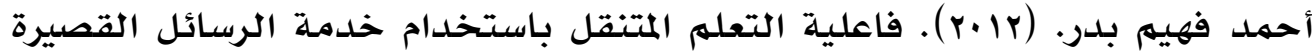
SMS

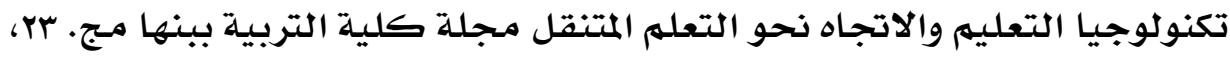

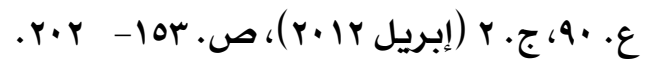




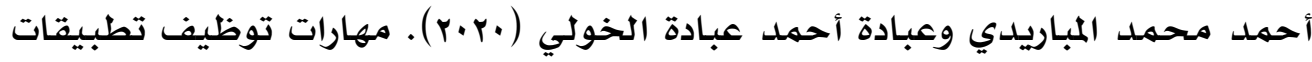

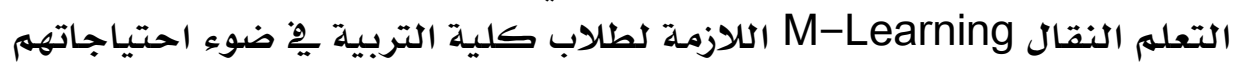
التدريبية. المجلة الدولية للبحوث فِ العلوم التربوية: المؤسسة الدولية لآفاق

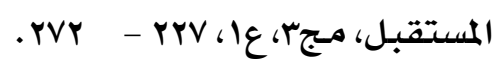

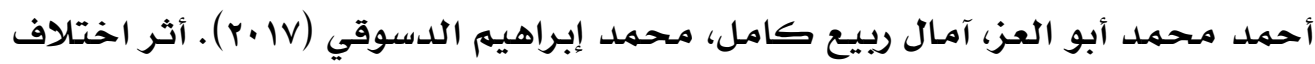

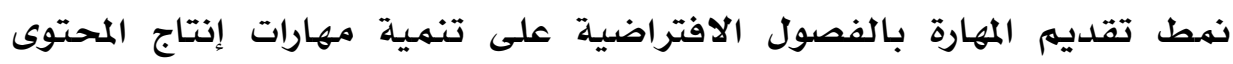
الإلكتروني لدى طلاب تكنولوجيا التعليهم. مجلة جامعة الفيوم للعلوم التربوية

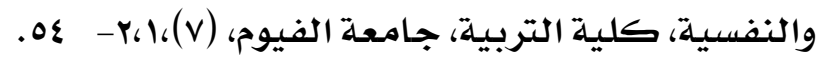

أمل السيد طاهر (YV). (Y). تصهيم المحتوى الإلكتروني. القاهرة: دار جوانا للنشر والتوزيـع.

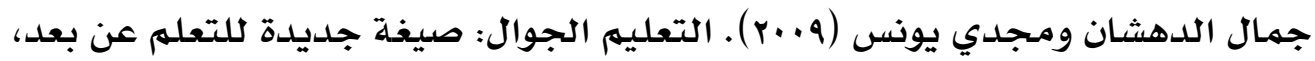

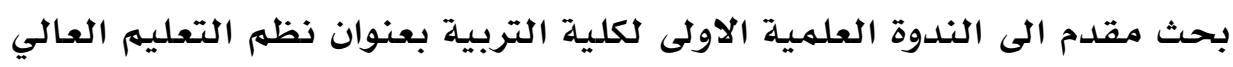
الافتراضي جامعتة كفر الشيخ، مصر.

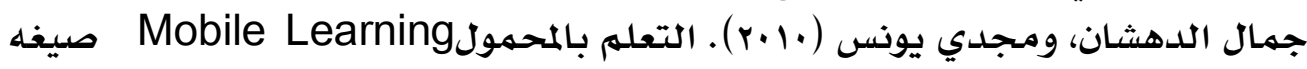
جديدة للتعلم عن بعد، سلطنة عهان، المؤتهر الدولي الاول للجهمعية العهمانية

$$
\text { لتكنولوجيا التعليهم. }
$$

حسن عبد العاطي (10 ب). توظيف الأجهزة النقالة الذكية واللوحية ِيخ التعله

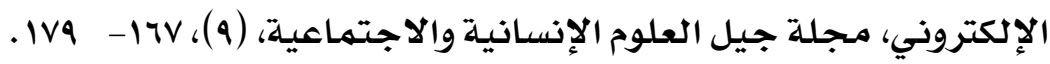

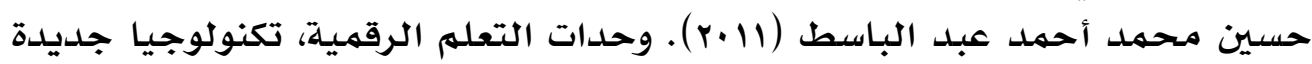

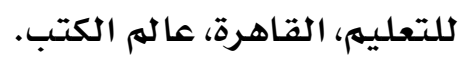

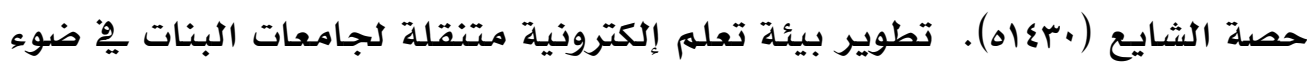

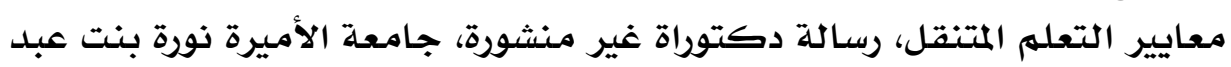

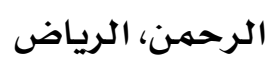

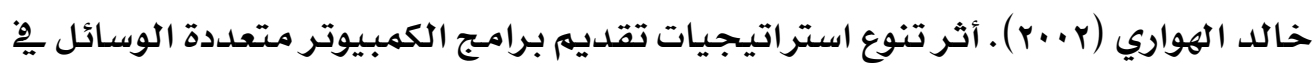

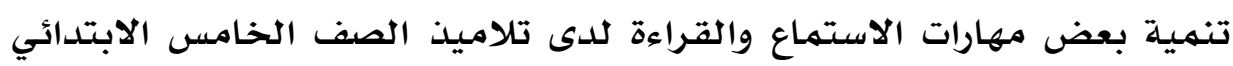
(رسالة دكتوراه غير منشورة) . كلية التربية، جامعة الأزهر.

خالد أحمد جمعه الخياط، أحمد محمد نوبي، ومحمد عطية خميس. "فاعلية تصميهم

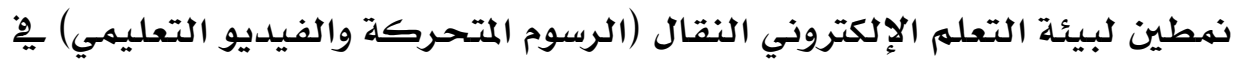

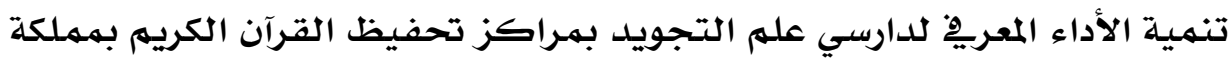




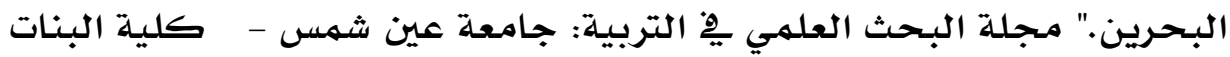

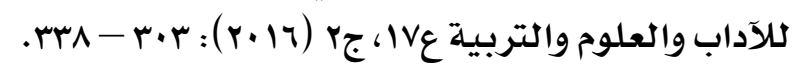

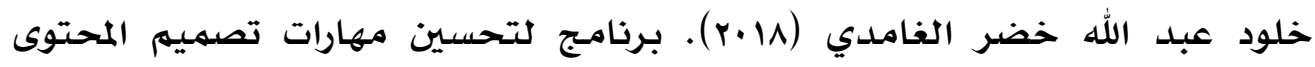

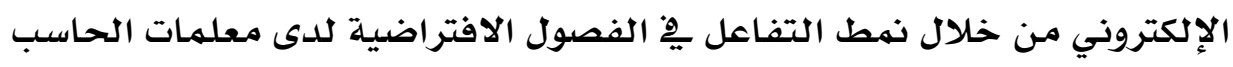
وتقنية المعلومات ِِ منطقة الباحة. المجلة الدولية للآداب والعلوم الانسانية

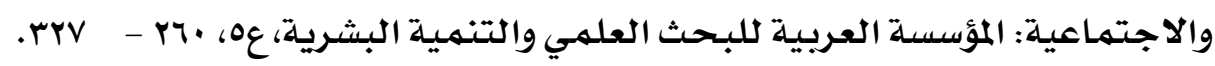

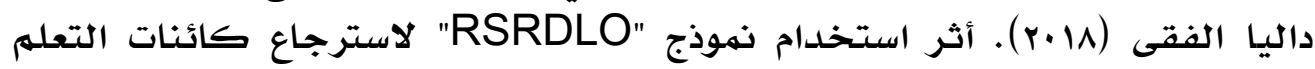
الرقمية يخ تنهية مهارات إنتاج المقررات الإلكترونية لدي طلاب الدراسـات بكلية

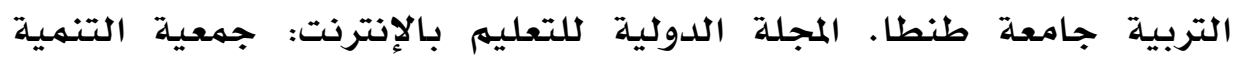

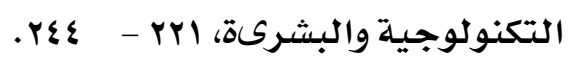

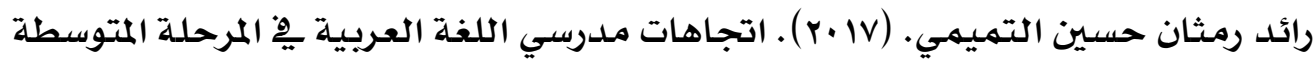

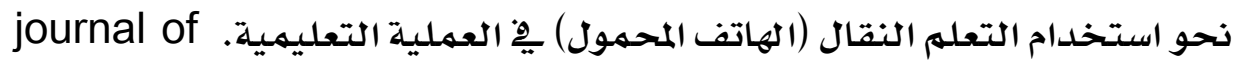
.) (rє) Human Sciences, 2

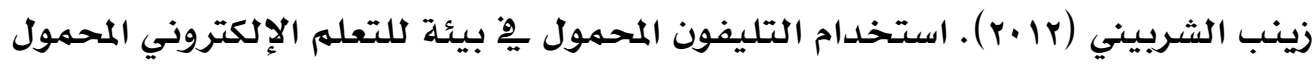
وأثره على تنهية مهارات تصهيه المحتوى الإلكتروني ونشره. مجلة كلية كلية التربية

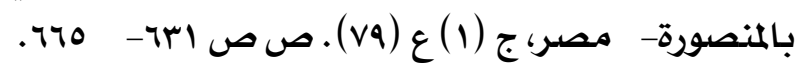

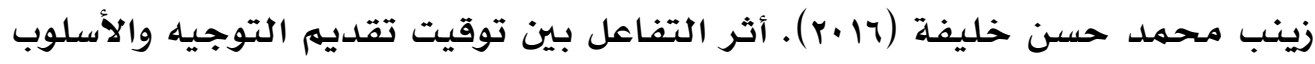

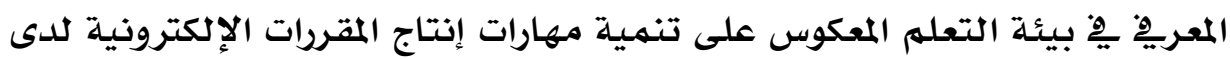

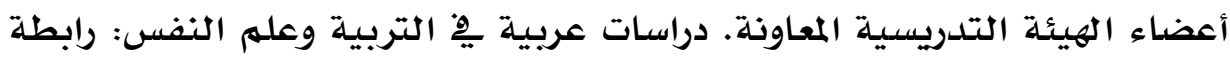

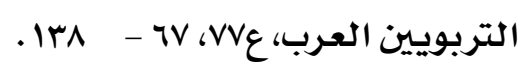

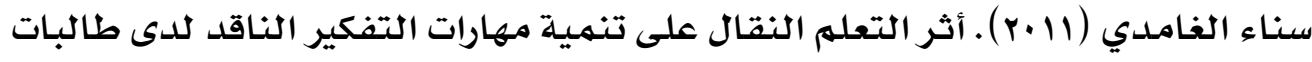

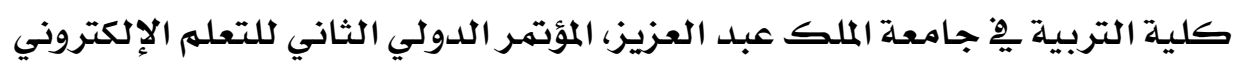

$$
\text { والتعليهم عن بعد، الرياض. }
$$

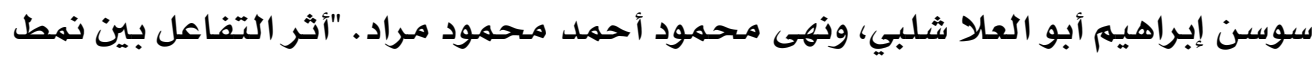

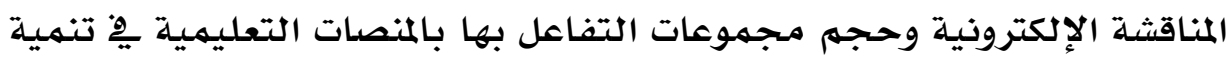

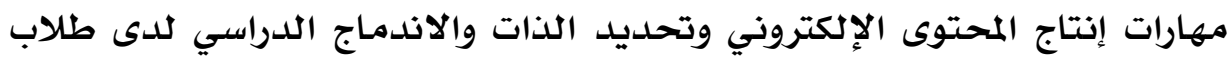

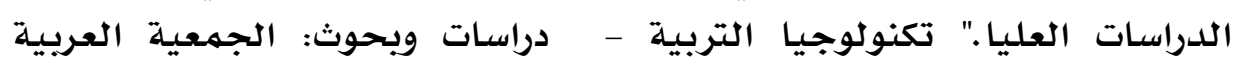

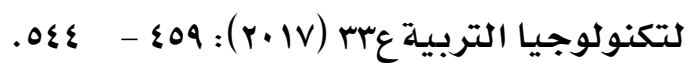

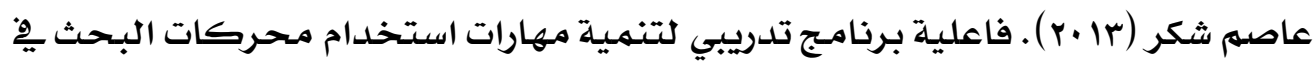

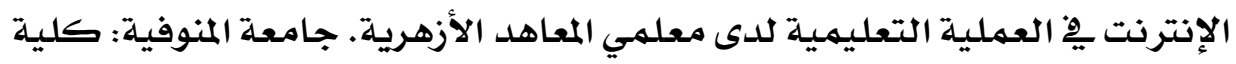




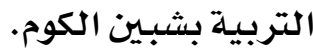

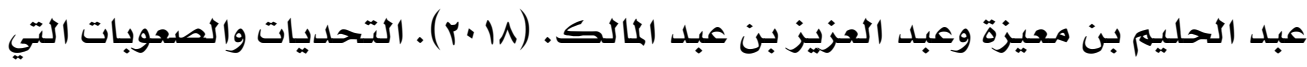

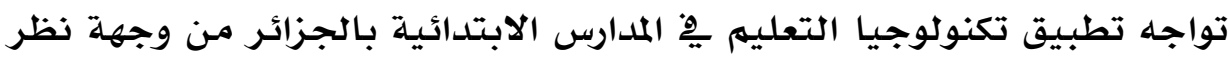

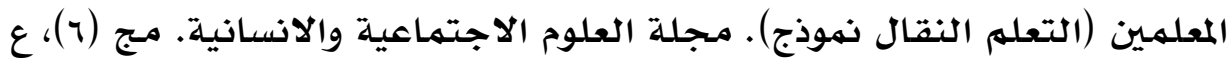

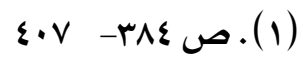

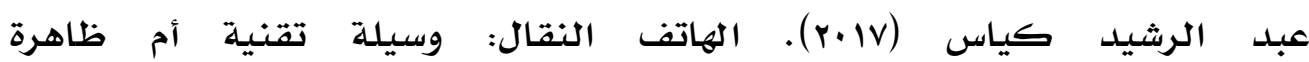

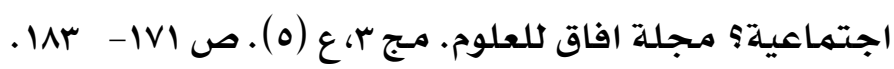

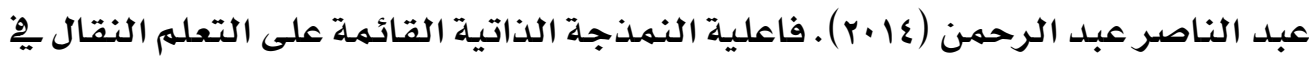

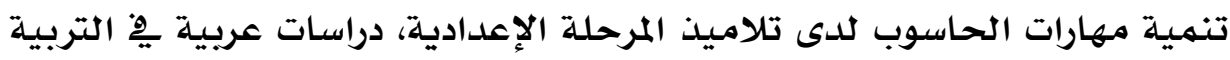

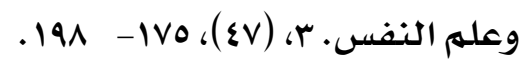

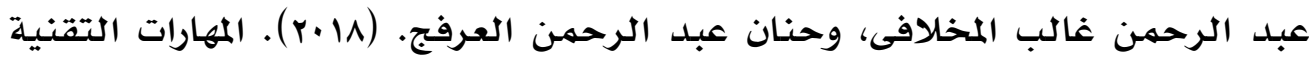

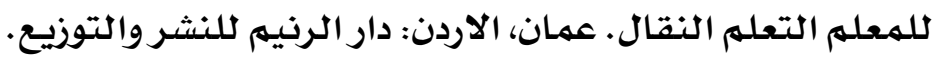

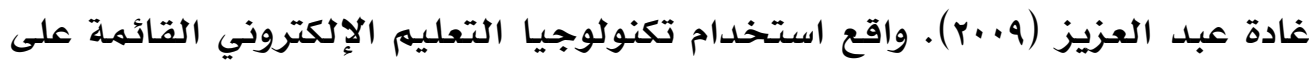

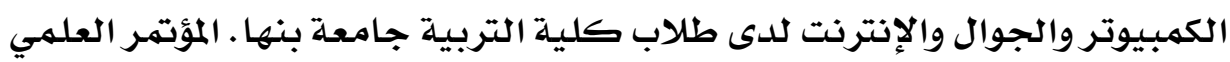

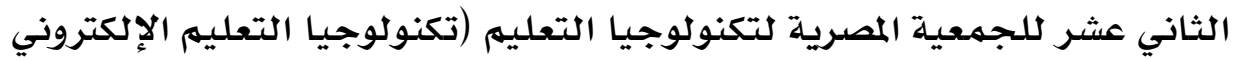

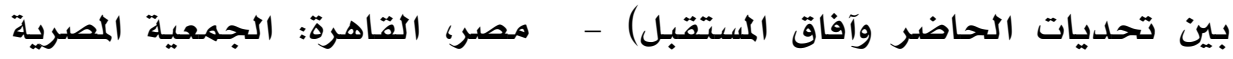

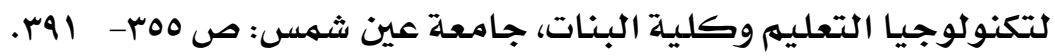

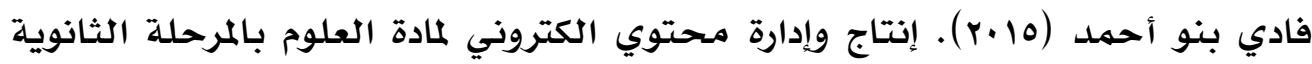

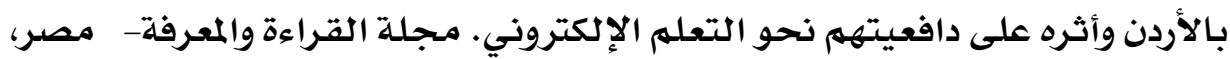

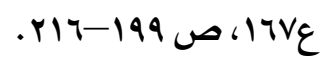

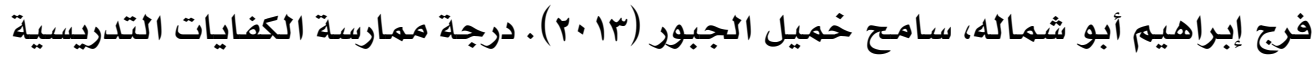

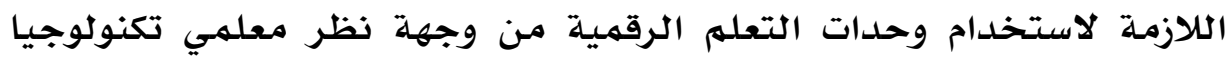

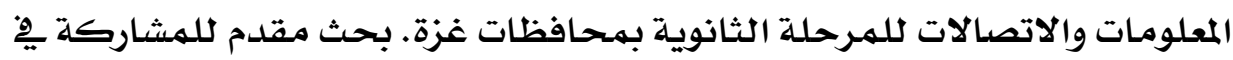

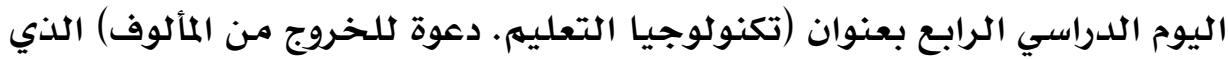

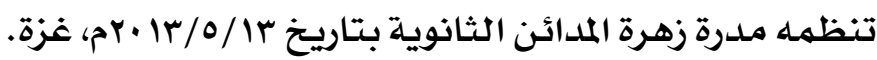

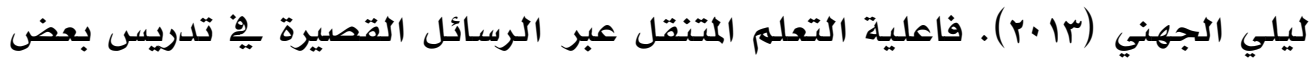

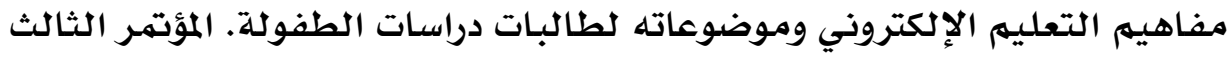

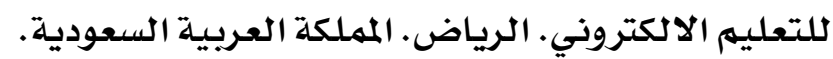

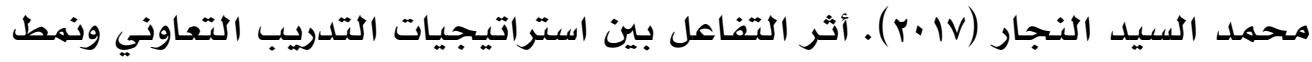

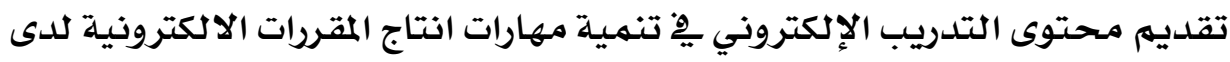


معلهي الحلقة الإعدادية. تكنولوجيا التربية- دراسات وبحوث، الجمعية العربية

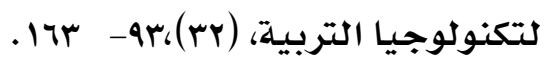

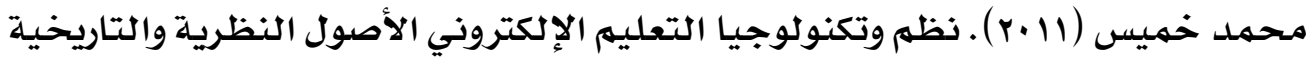

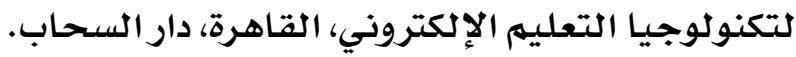

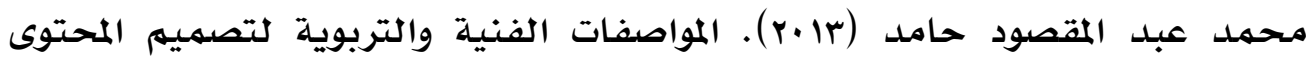

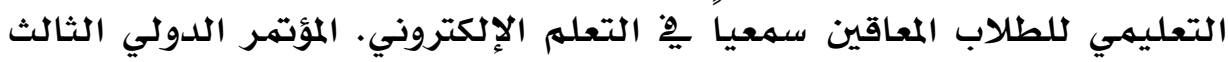

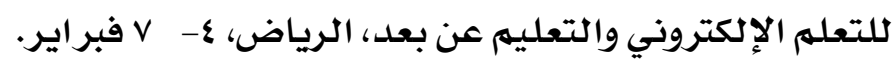

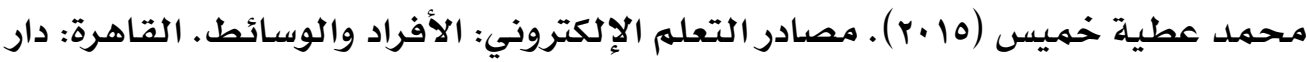
السحاب.

محمد أحمد عمر أحمد. "استراتيجية مقترحة قائمة على التعلهم النقال المنظم ذاتياً

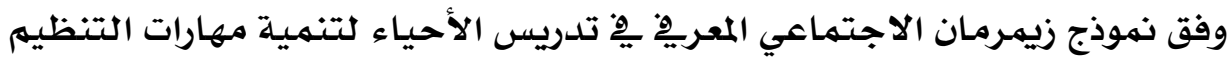

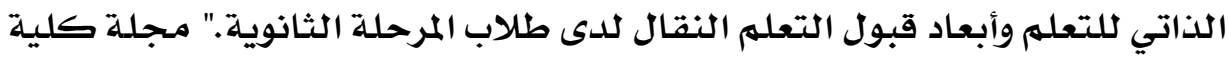

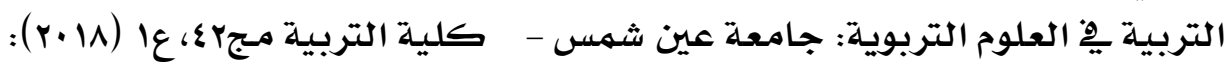
$.1 \% \cdot-1 \varepsilon$

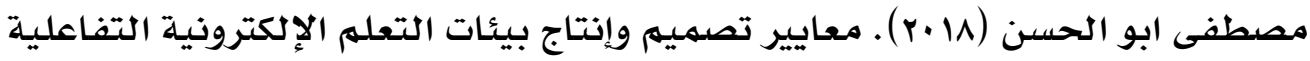

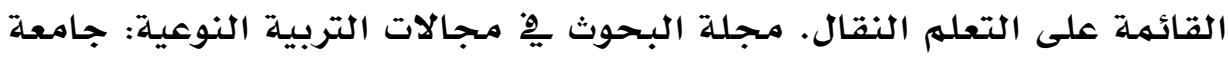

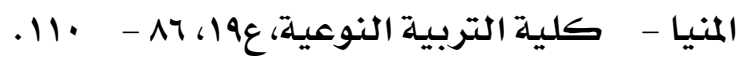

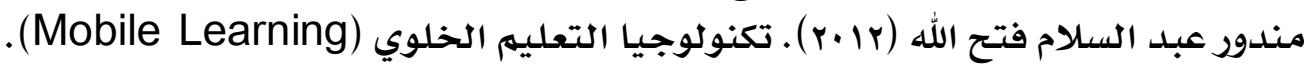

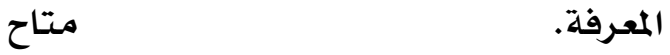
مجلة علي http://www.almarefh.net/show_content_sub.php?CUV=399\& Model=M\&SubModel=138\&ID=1648\&ShowAll=On

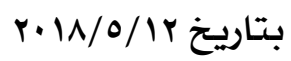

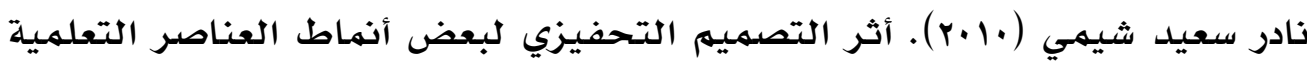

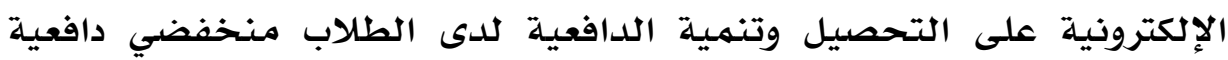

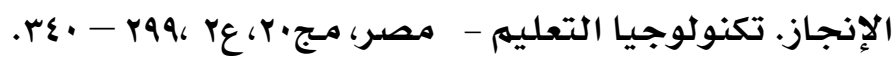

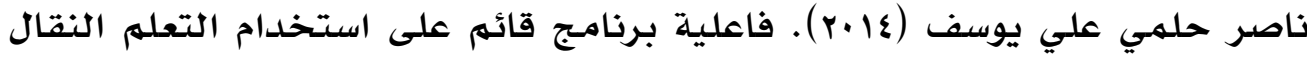

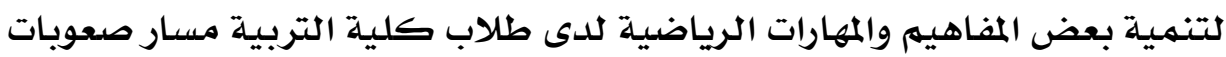

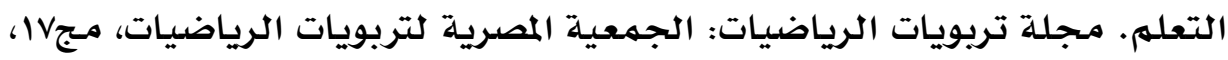

$$
\text { . Y19 - ITV، }
$$




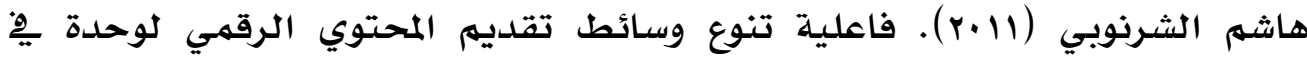
تكنولوجيا التعليه الإليكتروني النقال ونوع المهنـة فِ التحصيل والقابليـة للتعليه المستمـر لدى المتخصصسين يِ مجال تكنولوجيا التعليم واتجاهاتهم نحو التعلهم

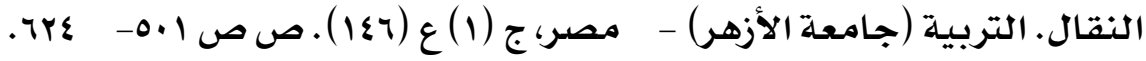
هالة عبد القادر سعيد (r/r.r) "مدى وعي طلاب جامعة الدمام باستخدام التعلهم

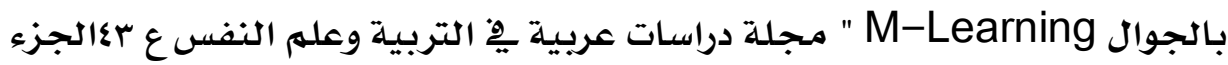

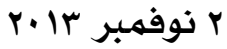

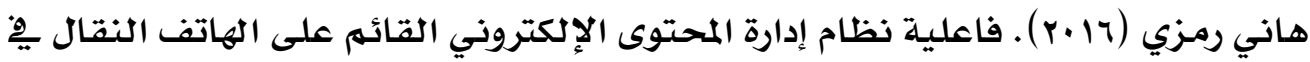
تنمية بعض مهارات استخدام المستحدثات التكنولوجية لدى معلى معلمي المرحلة الإعدادية. مجلة بحوث عربية فِ مجالات التربية النوعية- رابطة التربويـين

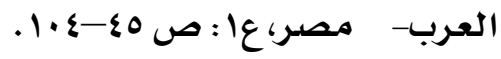

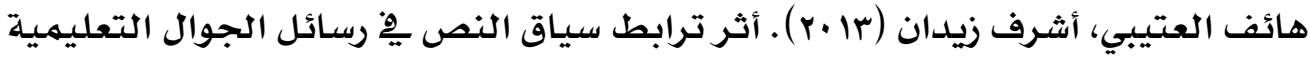
على تحصيل معاني مفردات اللغة الإنجليزية وبقاء أثر التعلهم لدى طلاب المرحلة

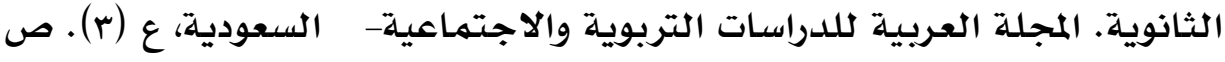
ص

وليد يسري عبد الحي الرفاعي (19 ب) ."بيئة تعلهم إلكترونية تكيفية قائمـة على نموذج

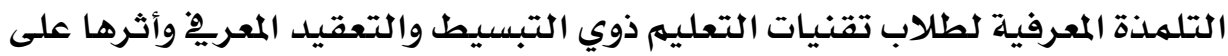
تنهية مهارات إنتاج المحتوى الرقهي وعمق المعرفة." مجلة التربية: جامعـة الأزهر

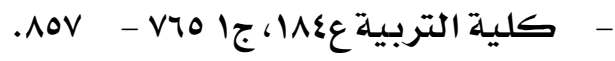

Ally, M. (2009). 8. In Mobile learning transforming the delivery of education and training (p. 173). Edmonton: AU Press.

Baran, E. (2014). A review of research on mobile learning in teacher education. Journal of Educational Technology \& Society, 17(4), 17.

Basoglu, Emrah \& Akdemir, Omur (2010). A comparison of undergraduate students> English vocabulary learning: using mobile phones and flash cards. Turkish Online Journal of Educational Technology- TOJET, 9 (3) p1-7.

Bradley, C., R. Haynes, and T. Boyle. 2005a. Design for multimedia m-learning: Lessons from two case studies. In 
Exploring the frontiers of e-Learning: Borders, outposts and migration, ed. J. Cook and D. Whitelock. Research proceedings of the 12th Association for Learning Technology Conference (ALT-C 2005), September 6-8, University of Manchester, England.

Crompton, H. (2013). A historical overview of mobile learning:

Toward learner-centered education. In Z. L. Berge \& L. Y.

Muilenburg (Eds.), Handbook of mobile learning (pp. 3-14).

Florence, KY: Routledge.

Crompton, H., Burke, D., Gregory, K.H. et al. J Sci Educ Technol

(2016) 25: 149. https://doi.org/10.1007/s10956-015-9597-x

Eryilmaz, S (2014). Learning Objects and the FATIH Project;

Proposal of a Model. International Journal of

Environmental and Science Education, 9m 4, PP 399-411

Eryilmaz, M. (2015). The effectiveness of blended learning

environments. Contemporary Issues in Education Research

(CIER), 8(4), 251-256.

Haiguang, F., Chenzhu, G., Pan, L., \& Cong, J. B. (2012, July).

The research on e-book-oriented mobile learning system environment application and its tendency. In 2012 7th International Conference on Computer Science \& Education (ICCSE) (pp. 1333-1338). IEEE.

Kaliisa, R., \& Picard, M. (2017). A Systematic Review on Mobile Learning in Higher Education: The African

Perspective. Turkish Online Journal of Educational Technology-TOJET, 16(1), 1-18.

Kert, S. (2011). The use of SMS support in programming education. TOJET: The Turkish Online Journal of Educational Technology, 10 (2), 268-273.

Madjarov, I., \& Boucelma, O. (2010, December). Learning 
content adaptation for m-Learning systems: a multimodality approach. In International Conference on Web-Based Learning (pp. 190-199). Springer, Berlin, Heidelberg.

Martin, F., \& Ertzberger, J. (2013). Here and now mobile learning: An experimental study on the use of mobile technology. Computers \& Education, 68, 76-85.

Prensky, M. (2009) What can you learn from a cell phone? Almost anything, Journal of Online Education, Vol. 1, Issue 5, June/July 2009

Vanwelsenaers, Marc (2012). Students using their own technology device in the classroom: can "byod" increase motivation and learning. (Un published Master thesis) in arts in education submitted to northern michigan university. 